\title{
Uma ferramenta para a visualização de ESTs
}

\author{
Delane Pereira de Oliveira Dias
}


SERVIÇO DE PÓS-GRADUAÇÃO DO ICMC-USP

Data de Depósito: 11 de dezembro de 2006

Assinatura:

\title{
Uma ferramenta para a visualização de ESTs $^{1}$
}

\author{
Delane Pereira de Oliveira Dias
}

Orientador: $\operatorname{Prof}^{a}$. Dr ${ }^{a}$. Rosane Minghim

Dissertação apresentada ao Instituto de Ciências Matemáticas e de Computação - ICMC/USP, como parte dos requisitos para obtenção do título de Mestre em Ciências de Computação e Matemática Computacional.

USP - São Carlos

Dezembro/2006

\footnotetext{
${ }^{1}$ Este trabalho recebeu apoio financeiro do CNPq.
} 


\section{Agradecimentos}

Enfim se encerra este ciclo que, acima de tudo, trouxe-me muitas alegrias. Acredito que tenho muitos motivos e pessoas para agradecer.

Em primeiro lugar agradeço à minha mãe, dona Risola, que me trouxe a este mundo e que sempre zelou por mim, dando-me palmadas quando precisava - e foram muitas as vezes - ou o seu colo para me confortar. É a melhor mãe do mundo. Eu te amo mãe.

Agradeço à minha orientadora Rosane Minghim e ao meu co-orientador Guilherme P. Telles por me darem suporte com ótimas idéias e críticas. Além disso, colaboraram muito para o meu crescimento pessoal.

Ao meu irmão, que sempre se preocupou comigo e deu muita força para estar aqui hoje.

À minha namorada por ter deixado que eu a encontrasse e por ficar sempre ao meu lado, tendo feito destes os melhores dias da minha vida.

Aos meus amigos da PgCompUSP-04, que fizeram com que o mestrado tivesse a alegria da graduação. Jamais esquecerei as jam sessions, os times de futebol, as brincadeiras e o companheirismo. Tenho certeza que daqui levarei amigos para o resto da vida.

Aos meus amigos de Campo Grande: Néstor, Guilherme, Fernando e Alberto. Obrigado pelas histórias sempre engraçadas e alto-astral. Alguns deles devo felizmente reencontrar em breve.

Ao meu amigão Rodriguinho, com quem mais devo ter conversado enquanto estávamos aqui. Aprendi muito com ele, mesmo que divergindo em vários aspectos. Tenho muito respeito por ele. Sempre muito divertido e nunca pra baixo. Saudades de nossas sessões de tereré. O cara é monstro... galo mesmo!

Ao meu amigo Jão que é um irmão de verdade pra mim. Por sorte e, principalmente, por sua indicação (=D) estaremos juntos em nossa nova fase profissional. Muita palhaçada nos aguarda meu companheiro de imitações. E dias melhores virão Jones.

Aos meus amigos Calvo e Adriano pelas madrugadas de discussões sobre a vida. Aprendi muito.

À minha família em Campo Grande, por ter me dado uma base e o conforto de um lar de verdade, com discussões, brigas, entreveros mas, acima de tudo, com muita alegria e amor.

Aos meus amigos de Campo Grande, para onde pretendo voltar um dia e ter o prazer de conviver com eles novamente.

Ao CNPq pelo apoio financeiro.

Enfim, por mais que se queira evitar, todo agradecimento é injusto com alguns e este não é diferente, mas acreditem, obrigado a todos que de alguma forma contribuíram comigo e permitiram que eu contribuísse com vocês. Todos vocês me tornaram uma pessoa melhor.

Obrigado! 
Expressed Sequence Tags (ESTs) são amostras de trechos de genes, que funcionam como moldes na síntese de proteínas. Como a quantidade de ESTs coletados nos últimos anos é muito grande, o uso de computadores tornou-se imprescindível para a identificação de genes, proteínas e para a descoberta de genes homólogos. Este trabalho propõe uma metodologia e implementa uma ferramenta para a visualização de ESTs através de um grafo para auxiliar biólogos na exploração e na descoberta de conhecimento sobre estas seqüências. A metodologia inclui agrupamento usando um programa montador de seqüências e, conseqüentemente, a transformação dos grupos em nós de um grafo. O algoritmo BLAST é usado para procurar alinhamentos entre sequiências, representando-os posteriormente por arestas entre as sequiências mais similares. Para a visualização do grafo utilizamos e modificamos a ferramenta TG WikiBrowser conectada a um banco de dados. O resultado é uma ferramenta interativa baseada em código livre e robusto que funciona em ambientes Windows e Linux. Ela possibilita a fácil exploração do grafo, com diversas funcionalidades como, por exemplo: a expansão e filtragem do grafo, a busca por rótulos ou trechos de sequiências e a visualização detalhada de seqüências e grupos de seqüências. Com isso, os biólogos e especialistas em bioinformática ganham mais uma alternativa de investigação da genética. 
Expressed Sequence Tags (ESTs) are samples of gene stretches, which play the role of templates in synthesis of proteins. Since the amount of collected ESTs on the past few years is enormous, the use of computers has become essential to fields like gene and protein identification, and gene homology. This work proposes a methodology and a tool for visualization of ESTs as a graph for aiding biologists on exploration and on knowledge discovery about these sequences. The methodology includes clustering of ESTs using an assembly program and, consequently, the transformation of the groups in nodes of a graph. BLAST algorithm is used to search alignments among sequences, later representing them as edges between the most similar sequences. For the graph visualization, we adapted TG WikiBrowser software connected to a database. The result is a robust and open source interactive tool for Windows and Linux. It allows easy graph exploration, with various functionalities, for example: graph expansion and filtering, searching for label or sequence stretches, and detailed visualization of sequences and groups of sequences. Therefore, we hope biologists can count on one more option in genetics research. 
Resumo

$\begin{array}{ll}\text { Abstract } & \text { ii }\end{array}$

Sumário $\quad$ iii

$\begin{array}{ll}\text { Lista de Figuras } & \text { v }\end{array}$

$\begin{array}{lll}\text { Lista de Tabelas } & \text { viii }\end{array}$

1 Introdução $\quad 1$

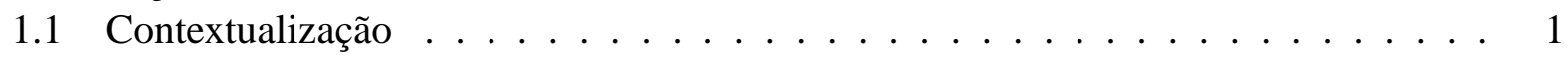

1.2 Motivação e objetivos . . . . . . . . . . . . . . . . . . . . . . 2

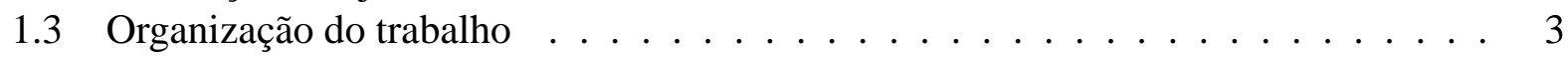

2 Revisão bibliográfica $\quad 4$

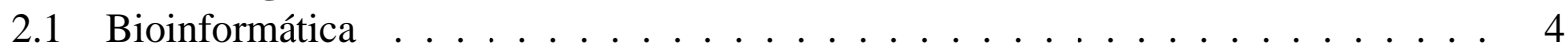

2.1.1 Alinhamento de seqüências . . . . . . . . . . . . . . 7

2.1.2 Montagem de sequiências . . . . . . . . . . . . . . . . . . . 8

2.2 Visualização de informação . . . . . . . . . . . . . . . . . . . . . . . 8

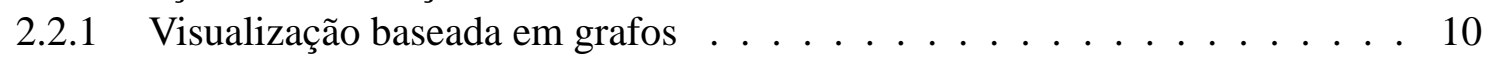

2.2 .2 Interação . . . . . . . . . . . . . . . . . . 15

2.3 Visualização aliada à bioinformática . . . . . . . . . . . . . . . . 18

2.3 .1 Trabalhos relacionados . . . . . . . . . . . . . . . 18

2.4 Considerações finais . . . . . . . . . . . . . . . . . 21

3 Expressed Sequence Tags $\quad 23$

3.1 Visão geral . . . . . . . . . . . . . . . . . . . 23

3.2 Definições importantes . . . . . . . . . . . . . . . . . 26

3.3 Seqüenciamento de ESTs . . . . . . . . . . . . . . . . 26

3.4 Considerações finais . . . . . . . . . . . . . . . . . . . . 29

4 Metodologia para a transformação dos dados $\quad 30$

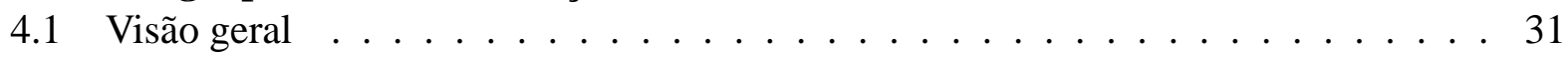

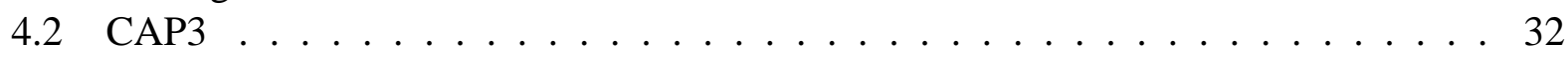

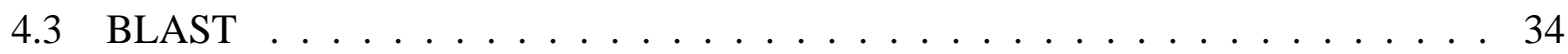


4.4 Construção do grafo e preparação da base de dados . . . . . . . . . . . . . . 37

4.5 Visualização dos ESTs . . . . . . . . . . . . . . . . . . . 40

4.6 Considerações finais . . . . . . . . . . . . . . . . . . 42

5 Resultados $\quad \mathbf{4 3}$

5.1 Funcionalidades . . . . . . . . . . . . . . . . . . 43

5.1 .1 Barra de funcionalidades . . . . . . . . . . . . . . 44

5.1 .2 Janela de busca . . . . . . . . . . . . . . . . . 46

5.1 .3 Janela de apresentação do grafo . . . . . . . . . . . . . . . . . . . 47

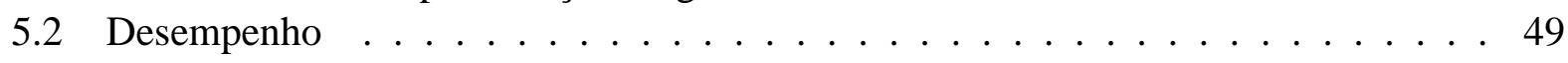

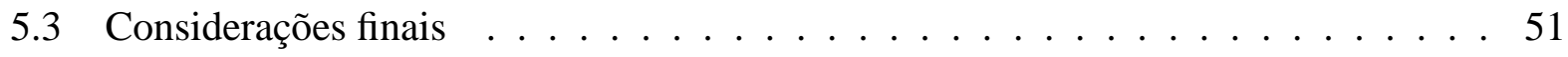

6 Conclusões $\quad 53$

6.1 Trabalhos futuros . . . . . . . . . . . . . . . . . 54

$\begin{array}{ll}\text { Referências Bibliográficas } & 56\end{array}$

$\begin{array}{ll}\text { Glossário } & 62\end{array}$ 


\section{Lista de Figuras}

2.1 Estrutura da seção de um DNA. Retirada de Wikipedia (2006). . . . . . . . . . . . 5

2.2 Seqüenciamento pelo método de terminadores de cadeia. Os símbolos precedidos por dd, como ddATP, representam os didesoxinucleotídeos. Retirada de Voet e Voet $(1995) \ldots \ldots \ldots \ldots \ldots \ldots$. . . . . . . . . . . . . . . . 6

2.3 Exemplo de apresentação de previsão do tempo utilizada em telejornais. Retirada de clicRBS (2006). . . . . . . . . . . . . . . . . . . . . 9 9

2.4 Parte da rede de relacionamentos sexuais ocorridos na Jefferson High School no período entre 1993 e 1995 . Retirada de Bearman et al. (2004). . . . . . . . . . . . . 11

2.5 Desenho do tipo baseado em força utilizando a metáfora de molas. Retirada de Cruz e Tamassia (2006). . . . . . . . . . . . . . . . . . . . 13

2.6 Passos utilizados pelos algoritmos de desenho oritentado a nível. Retirada de Niggemann (2002) . . . . . . . . . . . . . . . . . . . . 13

2.7 Diagrama da arquitetura de um circuito produzido por um algoritmo de desenho ortogonal. Retirada de Tom Sawyer Software (2006). . . . . . . . . . . . . . . . . 14

2.8 Desenho de uma rede de computadores produzido por um algoritmo de desenho circular. Retirada de Tom Sawyer Software (2006). . . . . . . . . . . . . . . . 15

2.9 Mapeamento de um site através de uma árvore hiperbólica, com temas destacados por cores. Retirada de Inxight (2006). . . . . . . . . . . . . . . . . . . . . 16

2.10 (a) Grafo representando os EUA, onde os vértices representam as suas maiores cidades e as arestas representam estradas entre cidades vizinhas. (b) Mesmo grafo sob efeito das visões olho-de-peixe. A cidade com maior destaque é St. Louis. Retirada de Sarkar e Brown (1994).

2.11 Etapas existentes desde a obtenção dos dados até sua apresentação visual. As setas curvas indicam o processo interativo de visualização, enquanto a seta tracejada indica que, mesmo durante a visualização, algumas requisições às ferramentas de bioinformática podem ocorrer. . . . . . . . . . . . . . . .

2.12 Visualização do trecho de uma seqüência consenso pelo método sequence logos. As letras que estão mais acima representam quais são as bases escolhidas para aquelas posições da seqüência. Foram utilizados 149 trechos de seqüências para criar este logo. Retirada de Schneider e Stephens (1990). . . . . . . . . . . . . . . . 19

2.13 Visualização da seqüência e da estrutura de uma molécula com a ferramenta STING. 20 
2.14 (a) Grafo do cluster Hs.75527 da base UniGene. (b) O mesmo grafo reduzido a apenas 3 partes devido à remoção das bifurcações que só acontecem para um pequeno número de ESTs. Os números sobre as arestas indicam a quantidade de ESTs que cada caminho possui. (c) O mesmo grafo especificado e com erros corrigidos. Retirada de Heber et al. (2002). . . . . . . . . . . . . . . . . . . . . . 21

3.1 Regiões de um gene. . . . . . . . . . . . . . . . . . . . . 24

3.2 Processo de transcrição. Retirada de Brooklyn College (2006). . . . . . . . . . . . 25

3.3 Sequiência de transformações na célula para a construção de transcritos a partir de um gene. Retirada de Telles (2002). . . . . . . . . . . . . . . . . . . 25

3.4 Obtenção do DNA fita dupla a partir do RNA. . . . . . . . . . . . . . . . . . 27

3.5 Clonagem dos cDNAs através de bactérias. Adaptada a partir de Telles (2002). . . 28

4.1 Metodologia adotada até a visualização do grafo. . . . . . . . . . . . . . . . 31

4.2 Formato FASTA do arquivo de ESTs. . . . . . . . . . . . . . . . 33

4.3 Funcionamento do montador CAP3. . . . . . . . . . . . . . . . . . . 34

4.4 Funcionamento do algoritmo BLAST para seqüências de DNA ou proteínas. (a) Mostra a lista de palavras da query. (b) Procura por hits em uma base de sequiências. (c) Estende o alinhamento para os hits. . . . . . . . . . . . . . . . . 36

4.5 Exemplo de hits duplos. Os eixos dos gráficos representam as bases de duas seqüências hipotéticas. Na figura, pode-se ver todos os hits, marcados por pontos, entre as duas sequiências. Entretanto, os únicos alinhamentos a serem estendidos possuem dois hits na mesma diagonal. . . . . . . . . . . . . . . . . . 37

4.6 Relatório de alinhamento gerado pelo BLAST. Acima na figura é mostrado o rótulo da seqüência com a qual a query fez alinhamento. No centro, diversas informações, entre elas a pontuação e o $e$-value. Mais abaixo é mostrado onde começa e termina o alinhamento entre as sequiências query e subject com as bases alinhadas por barras verticais. . . . . . . . . . . . . . . . .

4.7 União dos arquivos em um único arquivo de grafo. Os nomes separados pelo símbolo ' $x$ ' que aparecem acima dos arquivos indicam a ordem que foi realizada a busca de alinhamentos pelo BLAST. À esquerda de ' $\mathrm{x}$ ' são as seqüências subjects e à direita as queries. Esta ordem é indicada durante a visualização pelo desenho das arestas.

4.8 A base de dados é composta por três tabelas: a primeira armazena todas as seqüências originais, a segunda armazena somente os contigs e a terceira armazena informações de vértices remontados. . . . . . . . . . . . . . . . . . . . . . . . 40

4.9 Exemplos de aplicações feitas a partir do TouchGraph. . . . . . . . . . . . . . . . 41

5.1 As três partes da ferramenta: (1) barra de funcionalidades, (2) janela de busca e (3) janela de apresentação do grafo. . . . . . . . . . . . . . . . . . . . . . 44

5.2 (a) Filtro de $e$-value antes de ter seu valor reduzido e grafo correspondente. (b) Filtro com valor mais próximo de zero e grafo resultante. . . . . . . . . . . . . 45

5.3 À esquerda, a janela de busca e à direita, os sites: Google e Yahoo!. Nos círculos vermelhos, detalhes do negrito sobre o resultado.

5.4 Destaque dos vértices vizinhos ao vértice com rótulo 'SCSGFL4193B01.b'. Os vértices rotulados com 'Contig310' e 'Contig344' não são destacados pois estão selecionados. . . . . . . . . . . . . . . . . . . . 47

5.5 Os menus para vértices, arestas e plano de fundo. . . . . . . . . . . . . . . . . 48 
5.6 Detalhes do agrupamento 'Contig310'. Trechos das seqüências que aparecem em negrito são resultados de uma busca efetuada pelo usuário. . . . . . . . . . . . . . . . 48

5.7 (a) Selecionando opção de remontagem dos vértices selecionados. (b) Após a remontagem, o agrupamento 'Contig420' é gerado. O único vértice não montado permanece cinza, indicado pelo asterisco. . . . . . . . . . . . . . . . . . . 49

5.8 Diferenças de visualização em diferentes conjuntos de dados. (a) ESTs do projeto SUCEST após a aplicação do filtro de e-values. (b) ESTs do mosquito Aedes aegypti após a aplicação do mesmo filtro. 


\section{Lista de Tabelas}

5.1 Tempos de inicialização para conjuntos de dados de dados de diferentes tamanhos. As três primeiras linhas são relativas aos ESTs do projeto SUCEST. A última linha é relativa a um arquivo contendo ESTs coletados do DNA do mosquito Aedes aegypti, disponível para download no site Ensembl. . . . . . . . . . . . . . . . 50

5.2 Quadros por segundo atingidos durante a animação com diferentes interações e números de objetos visíveis. As interações de expansão e do filtro $e$-value aumentam e diminuem, respectivamente, o número de objetos visíveis na tela e, portanto, suas taxas de animações não correspondem exatamente ao número de objetos informados na tabela. 


\subsection{Contextualização}

O DNA está presente nas células de todos os seres vivos e codifica a informação para que eles sobrevivam e se reproduzam. A biologia molecular estuda todos os processos da vida na célula em nível molecular extraindo, desta forma, conhecimento e técnicas de várias disciplinas, incluindo bioquímica, citologia, genética, fisiologia, microbiologia, embriologia e evolução (Stansfield et al., 1996). A partir dos anos noventa, o uso de computadores se tornou essencial para a análise de dados provenientes da biologia, pois através de novas ferramentas biomoleculares foi possível o seqüenciamento em massa de genes e produtos de genes de vários organismos, havendo assim uma explosão de dados genômicos. O termo bioinformática foi cunhado em 1988 por Hwa A. Lim e se refere ao uso de computadores para manipular informação biológica. A disciplina, considerada essencial por biólogos moleculares, já produziu diversos algoritmos e programas para o estudo de seqüências genéticas, como o BLAST (Altschul et al., 1997), o CAP3 (Huang e Madan, 1999) e o PHRAP (Green, 1996).

Em outra área da computação, a visualização de informação busca aproveitar a capacidade visual humana para revelar padrões até então desconhecidos em grandes quantidades de dados (Oliveira e Levkowitz, 2003). Estes dados são abstratos, podendo não haver relação alguma entre eles e o mundo real. Outra característica deste tipo de visualização é a interferência do usuário, principalmente através de ferramentas de interação. Dentro deste contexto, a mineração visual de dados utiliza representações visuais interativas como resposta dos algoritmos de mineração de dados, que por sua vez buscam extrair padrões e regras de conjuntos de dados. Desta forma, a tendência é a de que um especialista do domínio tratado tenha maior controle sobre o processo de 
mineração dos dados. Algumas das áreas que contribuem com a visualização de informação são a computação gráfica, a interação humano-computador e a ciência cognitiva.

O foco deste trabalho está na união das ferramentas de bioinformática com as ferramentas de visualização de informação, proporcionando uma forma visual interativa de analisar e extrair conhecimento de dados transformados por algoritmos de bioinformática. Dentre os diversos tipos de dados, a atenção deste trabalho é voltada a dados representados por grafos. Grafos são estruturas com características importantes: simplicidade de representação e praticidade de uso. A simplicidade de representação dos grafos vem da sua representação por apenas duas estruturas (vértices e arestas) e a praticidade de uso vem da familiaridade, já que muitos dos problemas possuem dados que são diretamente expressos por grafos ou que podem facilmente ser transformados em um.

Este trabalho foi desenvolvido dentro do projeto InfoVis2 do grupo de Computação Gráfica e Processamento de Imagens do ICMC - USP. O projeto aborda a visualização e a mineração visual, já tendo gerado várias técnicas e aperfeiçoado outras para exploração visual de dados. O InfoVis2 tem como objetivo, entre outras coisas, disponibilizar um repositório de técnicas de visualização e mineração visual que possam ser acessadas remotamente, atuem de forma integrada e sejam adaptáveis às necessidades do usuário. Os arquivos correspondentes aos códigos fontes da ferramenta desenvolvida e outros detalhes do projeto estão disponíveis no endereço eletrônico http://infoserver.lcad.icmc.usp.br/infovis2.

\subsection{Motivação e objetivos}

Na última década, com a introdução de novas técnicas e ferramentas para o seqüenciamento de genomas, houve um grande acúmulo de seqüências genéticas de diversos organismos. Uma das inovações foi o seqüenciamento somente das partes que contêm genes de um organismo e não de todo o seu genoma. Este novo método de sequienciamento trouxe um grande avanço para a investigação de genes, pois uma vez que as partes com genes correspondem a somente cerca de $5 \%$ de todo o genoma de organismos eucariotos ${ }^{1}$, o seqüenciamento de genes passou a se dar com uma velocidade muito maior. Com isso, a busca por algoritmos que ajudassem analisar tais seqüências teve grande crescimento. Dentro da bioinformática, os maiores esforços se concentram em alinhamento de seqüências, descoberta de genes, montagem de sequiências, predição de proteínas e modelagem da evolução (Wikipedia, 2006).

Com os dados genéticos sendo coletados mais rapidamente, iniciou-se a busca por formas de interpretá-los e, uma delas, é a visualização de informação. Com o passar dos anos e com a evolução dos computadores, os tipos de visualização foram ganhando cada vez mais interatividade e sofisticação, possibilitando diversas maneiras de se visualizar dados. A exploração visual em

\footnotetext{
${ }^{1}$ Organismos que possuem células complexas, tais como plantas, animais e fungos, onde o núcleo e o citoplasma encontram-se separados por uma membrana, além de conter outras diversas organelas com funções específicas (Voet e Voet, 1995).
} 
grafos é uma área crescente, possuindo diversas aplicações: web mining, comércio eletrônico, biologia, química e telecomunicações são só alguns exemplos. Com isso, uma ferramenta baseada em grafos tem potencialidade de uso em várias aplicações. No entanto, os trabalhos que tratam da interferência do usuário no processo exploratório ainda precisam ser melhor estudados e comparados e uma ferramenta desta natureza pode contribuir neste contexto.

Este trabalho apresenta a metodologia e um sistema interativo para extrair conhecimento de dados da biologia molecular, especificamente ESTs ${ }^{2}$, permitindo a livre manipulação dos dados e, desta forma, poupando custos computacionais por meio da utilização do conhecimento do usuário. Para a transformação dos ESTs em grafos, utilizamos o programa de montagem CAP3 de Huang e Madan (1999) na montagem de grupos de sequiências parecidas entre si. Tais grupos são representados por vértices no grafo. Para a definição de arestas, foi usado o algoritmo BLAST de Altschul et al. (1997), que faz alinhamentos entre sequiências e atribui valores a estes alinhamentos. Por fim, o programa de visualização de grafos TG WikiBrowser de Shapiro (2006) serviu como base para a ferramenta visual que foi desenvolvida. O programa TG WikiBrowser sofreu diversas modificações e inclusões de funcionalidades para aumentar o poder de interação por parte do usuário. O resultado foi uma ferramenta bastante interativa, possuindo funcionalidades como: filtros, navegação sobre os dados e consultas dinâmicas. Espera-se que esta ferramenta tenha potencial para ajudar os biólogos no estudo sobre os ESTs e seus genes.

O projeto foi baseado em código livre e aberto, facilitando o acesso ao seu uso.

\subsection{Organização do trabalho}

O presente trabalho é organizado da seguinte forma: o Capítulo 2 faz uma revisão bibliográfica sobre bioinformática e visualização de informação, além da proposta para união destas duas áreas neste trabalho; o Capítulo 3 traz vários conceitos sobre biologia molecular e mostra como os ESTs são obtidos em laboratório; o Capítulo 4 descreve a metodologia adotada, ou seja, a sequiência de algoritmos e processos utilizados até que a visualização dos dados fosse alcançada, descrevendo os vários algoritmos utilizados; o Capítulo 5 mostra os resultados obtidos pela nova ferramenta, mostrando em detalhes suas características, tanto em termos de funcionalidades quanto de desempenho; e o Capítulo 6 traz conclusões e discussões sobre o trabalho, além de apresentar algumas propostas para trabalhos futuros.

\footnotetext{
${ }^{2}$ Expressed Sequence Tags (ESTs) são pequenos trechos - produzidos em laboratório - de genes. Ver Capítulo 3.
} 


\section{Revisão bibliográfica}

Este trabalho propõe uma nova maneira para visualizar certos dados genéticos, abrangendo assim duas grandes áreas: bioinformática e visualização de informação. As Seções 2.1 e 2.2 trazem um pouco dos conceitos básicos, da história, do desenvolvimento e do escopo de cada uma. Dentro da visualização de informação nos restringiremos à visualização em grafos por ser a representação visual adotada neste trabalho. Ainda, é discutida a importância das tarefas de interação no processo de visualização.

A Seção 2.3 traz a união das duas áreas - que é onde nossa abordagem se insere - através de alguns trabalhos relacionados

\subsection{Bioinformática}

Em 1977 ocorreu o primeiro seqüenciamento de um código genético (Wikipedia, 2006). O organismo que teve seu código seqüenciado foi o fago $\Phi$-X174, que é um vírus parasita de bactérias e tem pouco mais de 5.000 pares de bases de DNA. Entretanto, muitos biólogos não classificam os vírus como organismos vivos, argumentando que, na ausência de um hospedeiro, eles são biologicamente inertes (Voet e Voet, 1995). Somente em 1995 é que foi seqüenciado o primeiro genoma de um organismo considerado vivo, a bactéria Haemophilus influenzae, com 1.830.140 pares de bases de DNA contendo 1.740 genes. O projeto foi realizado pelo TIGR (The Institute for Genomic Research), que mais tarde se tornou o principal centro de seqüenciamento de genomas microbiais, além da participação no Projeto Genoma Humano ${ }^{1}$.

\footnotetext{
${ }^{1}$ Ver Venter et al. (2001).
} 
O seqüenciamento de uma cadeia de DNA revela a disposição das suas bases. O DNA é uma molécula fita dupla que armazena as informações relativas ao desenvolvimento biológico de uma forma de vida celular e de alguns vírus. As fitas são compostas pelas bases adenina, citosina, guanina e timina, respectivamente representadas pelas letras A, C, G e T. As extremidades livres do DNA são chamadas de 5' e 3'. As fitas do DNA ficam ligadas através de pontes de hidrogênio entre as bases. As bases $\mathrm{A}$ de uma fita se ligam às bases $\mathrm{T}$ da outra fita, enquanto as bases $\mathrm{C}$ se ligam às bases $\mathrm{G}$ e vice-versa. Eventualmente, trechos das fitas de DNA se desligam para dar início ao processo de síntese de proteínas (ver Capítulo 3). A Figura 2.1 ilustra superficialmente como é a estrutura de uma molécula de DNA.

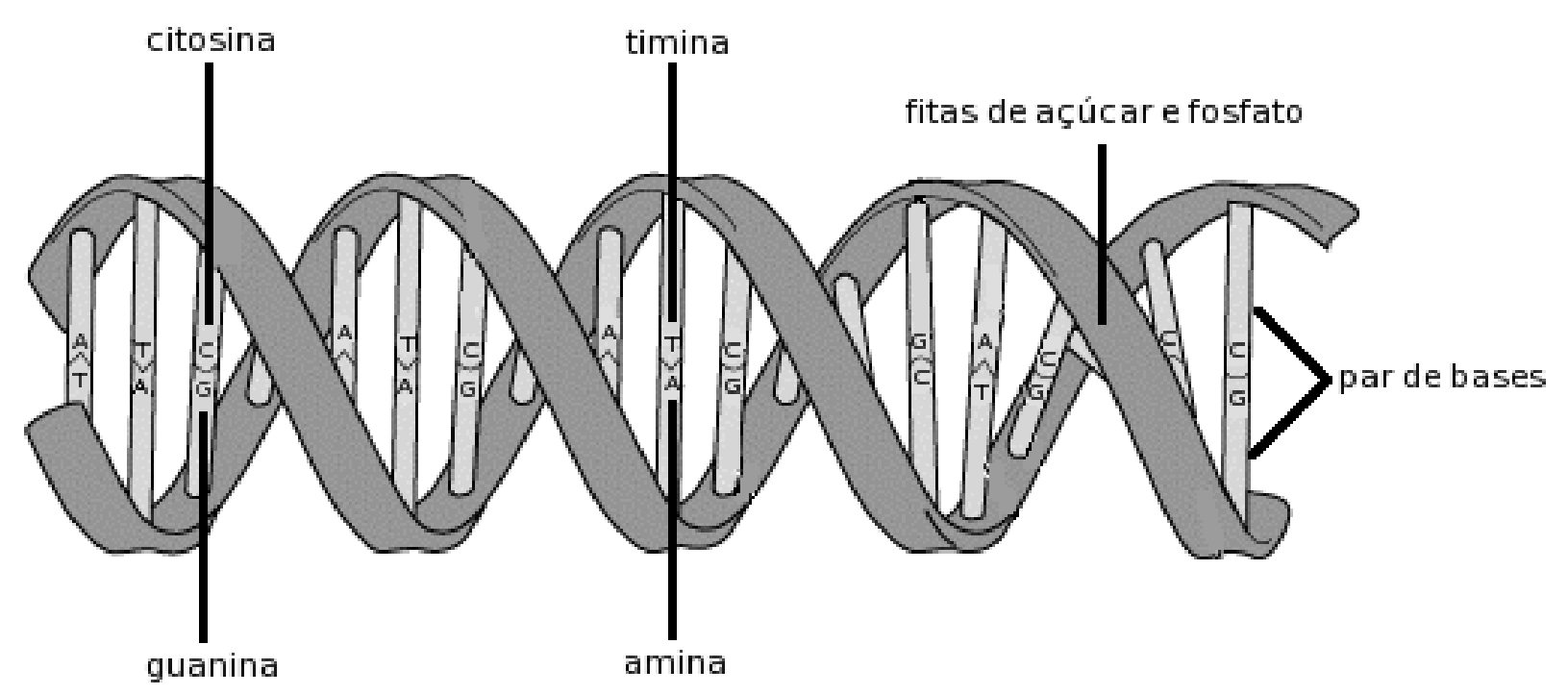

Figura 2.1: Estrutura da seção de um DNA. Retirada de Wikipedia (2006).

O método de seqüenciamento de DNA mais conhecido é o método de terminadores de cadeia, ou método de Sanger (Sanger et al., 1977). Esta técnica trabalha com fragmentos de DNA fita simples como molde. Estes fragmentos podem ser obtidos com a utilização de enzimas de restrição (ver Seção 3.2). Quatro amostras de DNA - uma amostra para cada base possível - a ser seqüenciado são separadas para que tenham suas fitas complementares de DNA sintetizadas. Estas amostras são colocadas juntas com um trecho curto de DNA, chamado primer. O primer é necessário para se ligar ao início do DNA molde e permitir que o DNA polimerase - enzima que cataliza a replicação do DNA - estenda bases complementares do DNA molde a ele. As bases são sintetizadas pelos quatro blocos de construção de DNA (desoxinucleotídeos trifosfato ou dNTPs). Junto a tudo isso, é colocada uma pequena quantidade de um dos quatro tipos de nucleotídeos terminadores de cadeia (didesoxinucleotídeos trifosfato ou ddNTPs), ou seja, cada mistura recebe um tipo de terminador de cadeia. Os didesoxis são marcados por rádio ou fluorocromos para possibilitar a sua leitura posteriormente. Quando um destes didesoxis é incorporado à cadeia complementar crescente no lugar de um nucleotídeo normal, o crescimento se encerra. Desta forma, para cada amostra, uma série de cadeias truncadas é gerada, onde cada uma é terminada por um didesoxi 
correspondente a sua respectiva base. A eletroforese em gel $^{2}$ separa estas cadeias de acordo com o seu tamanho e indica em quais posições as bases ocorrem devido à presença dos didesoxis. As marcas dos didesoxis aparecem com o uso de raios X ou luz UV, dependendo se foram marcados por rádio ou por fluorescência. Isto possibilita que a sequiência de DNA seja lida diretamente, dando origem ao termo read. A Figura 2.2 ilustra todo o processo descrito.

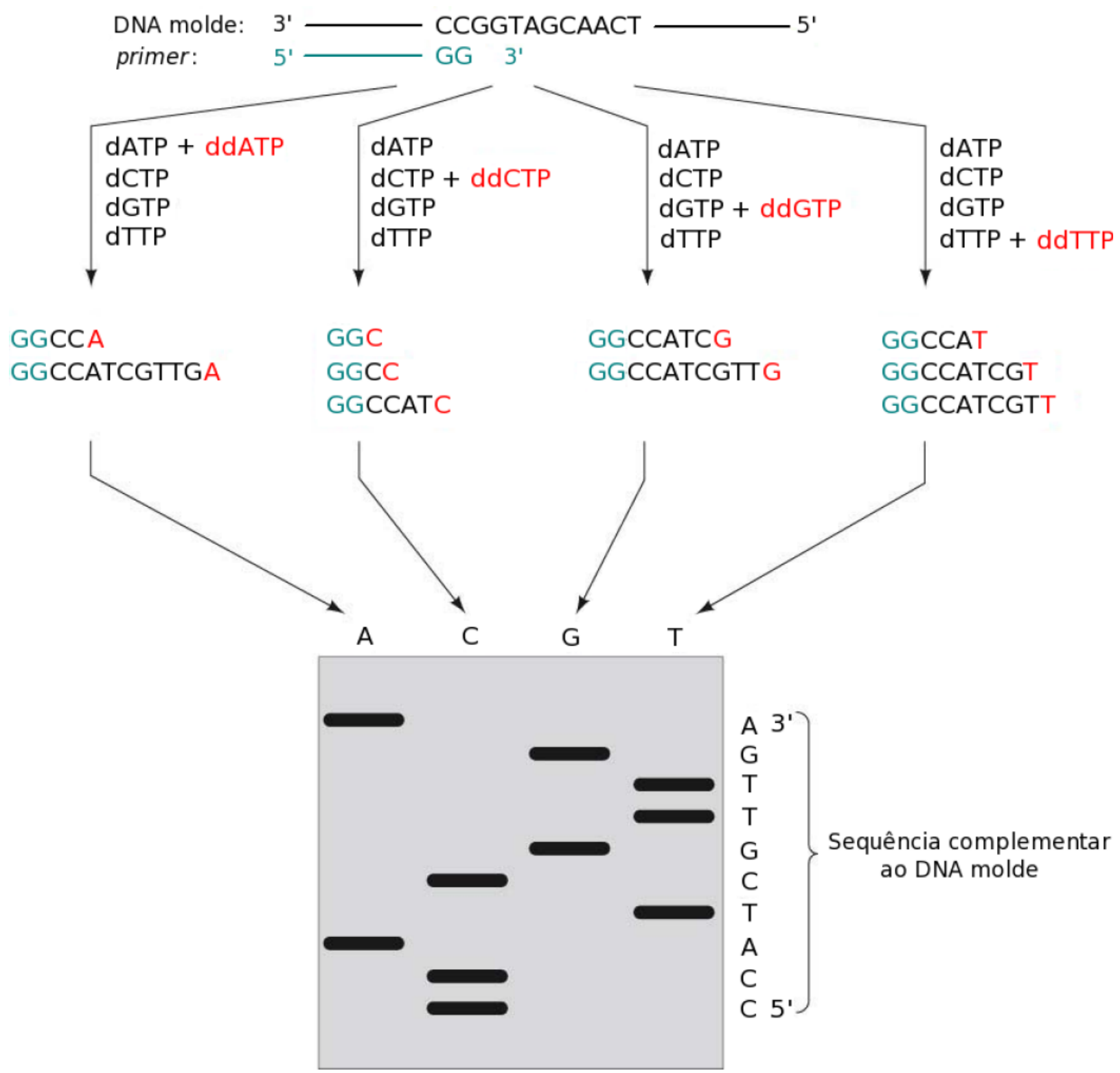

Figura 2.2: Seqüenciamento pelo método de terminadores de cadeia. Os símbolos precedidos por dd, como ddATP, representam os didesoxinucleotídeos. Retirada de Voet e Voet (1995).

Este processo de seqüenciamento é somente um exemplo das técnicas existentes. Mesmo o método de Sanger possui suas variações como, por exemplo, a marcação dos terminadores de

\footnotetext{
${ }^{2}$ Método de separação de moléculas grandes (como o DNA) de uma mistura de moléculas similares. Uma corrente elétrica passa através de um meio contendo a mistura e cada tipo de molécula se move por este meio em uma velocidade diferente, dependendo de sua carga elétrica e tamanho. Géis de agarose e acrilamida são meios comumente utilizados na eletroforese de proteínas e ácidos nucleicos (HGPI, 2006).
} 
cadeia (os didesoxis) por diferentes tons de fluorescência. Por este método é possível realizar o seqüenciamento com apenas uma amostra do DNA molde, ao invés de quatro, como foi descrito anteriormente, pois cada tipo de didesoxi emite sua fluorescência em um diferente comprimento de onda de luz UV. Outros exemplos de técnicas de seqüenciamento são os: seqüenciamento 454 (454 Life Sciences, 2006), seqüenciamento por hibridização (Preparata e Upfal, 2000) e piroseqüenciamento (Biotage, 2006).

A partir das técnicas de seqüenciamento, diversos organismos tiveram e vêm tendo seus genomas decodificados e armazenados em bases de dados. Com isso, tornou-se impraticável analisar as seqüencias de DNA manualmente. Esses dados são analizados para identificar genes e proteínas, assim como para comparar genes dentro de uma espécie ou entre espécies para mostrar funções similares de proteínas e ancestrais em comum - os genes homólogos. Na realização de todos estes processos, a Biologia recebe o auxílio da Matemática e da Computação, dando origem à bioinformática. Este termo, criado por Hwa A. Lim, recebeu definição formal do comitê de definição BISTIC (BISTIC, 2000), que diz que bioinformática é tudo o que se refere a:

"Pesquisa, desenvolvimento ou aplicação de ferramentas computacionais e abordagens para a expansão do uso de dados biológicos, médicos, comportamentais ou da saúde, incluindo aquelas para adquirir, armazenar, organizar, arquivar, analisar ou visualizar tais dados."

O mesmo comitê que fez esta definição reconhece que nenhuma definição sobre bioinformática pode evitar variações de interpretação. Portanto, é comum encontrar muitas outras definições, como esta em Wikipedia (2006):

"Bioinformática se refere ao uso de técnicas da matemática aplicada, informática, estatística e ciência da computação para solucionar problemas de biologia molecular.”

Os maiores esforços dentro da bioinformática se concentram em alinhamento de seqüências, descoberta de genes, montagem de seqüências, predição de proteínas e modelagem da evolução. $\mathrm{O}$ alinhamento e a montagem de sequiências atuam, respectivamente, na descoberta de trechos similares entre seqüências e na construção das seqüências originais. Alinhamento e montagem serão termos comuns neste texto, uma vez que são partes fundamentais para o processamento dos dados utilizados como entrada na ferramenta de visualização desenvolvida.

\subsubsection{Alinhamento de seqüências}

O alinhamento de seqüências promove a tentativa de revelar similaridades entre seqüências de DNA ou proteínas através da sobreposição das suas bases. Um alinhamento pode ser dito global ou local, sendo que cada tipo possui seu respectivo propósito. O alinhamento global realiza o alinhamento entre sequiências inteiras, procurando pelo melhor alinhamento existente entre elas. Já 
o alinhamento local encontra similaridades entre trechos de seqüências, por exemplo, as posições 20 a 40 de uma seqüência A podem ser alinhadas às posições 60 a 80 de uma sequiência B.

Um dos programas heurísticos mais utilizados para a realização do alinhamento local é o BLAST. Ele utiliza uma medida baseada em pontuações (scores) para todas as bases das seqüências, onde casamentos (matches) entre bases recebem valores positivos e divergências (mismatches) recebem valores negativos. Um segmento de seqüência é um trecho contínuo de bases de qualquer tamanho e a pontuação de similaridade para dois segmentos alinhados é a soma dos valores de similaridade de cada par de bases alinhadas (Altschul et al., 1990). As pontuações dos alinhamentos são dadas por uma matriz. Estas matrizes são das famílias PAM ou BLOSUM (Dayhoff et al., 1978; Ng et al., 2000), entre outras. Há outros algoritmos que realizam o alinhamento local de sequiências como o FASTP (Lipman e Pearson, 1985), o Gapped BLAST e o PSI-BLAST (Altschul et al., 1997). Estes dois últimos permitem o alinhamento de seqüências com a possível inserção de buracos (gaps) e são mais rápidos. Utilizaremos, por simplicidade, o nome BLAST para nos referir à versão que permite alinhamentos com buracos.

É natural concluir que, como o BLAST trabalha com seqüências decodificadas em letras, o algoritmo também possa contribuir no estudo de outros campos, como a evolução das linguagens e a busca por similaridades entre textos. Mais detalhes do funcionamento do algoritmo BLAST podem ser encontrados no Capítulo 4.

\subsubsection{Montagem de seqüências}

A montagem de seqüências é o processo de agrupar pequenas sequiências de DNA geradas, por exemplo, por clonagem (ver Seção 3.3), em grupos chamados contigs e montar, para cada grupo, uma representação da seqüência original. Esta representação montada da seqüência original recebe o nome de consenso.

Em Huang e Madan (1999) é apresentada a terceira geração do montador CAP, originalmente em Huang (1992). O CAP3 possui três passos principais: (1) remoção de trechos ruins das seqüências, (2) comparação de seqüências curtas - reads - através de um algoritmo de hashing e agrupamento quando elas possuírem bons alinhamentos entre si e (3) montagem das seqüências de cada grupo em uma única seqüência consenso que as represente. Outros exemplos de montadores são o TIGR Assembler (Sutton et al., 1995) e o PHRAP (Green, 1996). Mais detalhes do montador CAP3 podem ser encontrados no Capítulo 4.

\subsection{Visualização de informação}

A visualização, em sua forma genérica, vem sendo utilizada pelos seres humanos há séculos através de importantes ferramentas de representação, tais como mapas, desenhos científicos, gráficos e etc. Dentro da computação, a visualização herdou diversas idéias dessas representações 
como, por exemplo, as apresentações de previsão do tempo utilizadas em telejornais (ver Figura 2.3), onde com uma única imagem é possível saber o clima e a temperatura de várias regiões de um país, além de outros fenômenos meteorológicos.

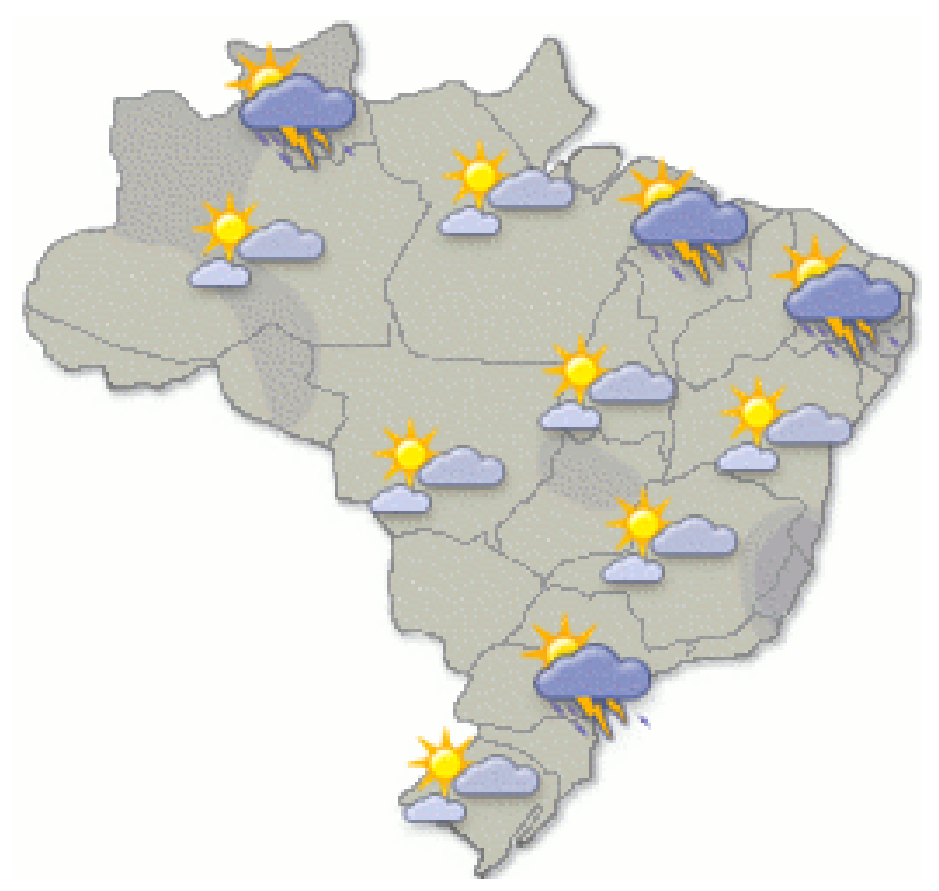

Figura 2.3: Exemplo de apresentação de previsão do tempo utilizada em telejornais. Retirada de clicRBS (2006).

Na década de 80, a visualização de informação surgiu como uma nova área com sua teoria baseada na computação gráfica, na interação humano-computador e na ciência cognitiva. Card et al. (1999) definem a visualização de informação da seguinte forma:

"Visualização de informação é o uso de representações visuais, interativas e suportadas por computador; de dados abstratos para ampliar a cognição."

Dados abstratos são aqueles que não possuem necessariamente uma relação direta com o mundo real, ou seja, podem não descrever fenômenos físicos reais, ao contrário dos dados para a visualização científica. Ainda, dados abstratos podem ser multidimensionais, dificultando seu mapeamento. Um bom exemplo de dado abstrato e multidimensional é uma base de dados contendo o histórico de navegação na Internet por parte de usuários. Cada entrada pode conter o nome do usuário, idade, profissão, sites visitados por ele, quais os temas destes sites, horários de acesso e etc. Esta informação, por si só, é abstrata e cada dimensão é caracterizada por um atributo diferente. A partir destes dados, buscam-se formas de apresentá-los e explorá-los visualmente de maneira que padrões sejam descobertos e hipóteses sejam levantadas, como caracterizar o perfil de usuários de determinados sites. Para uma empresa que possui um site, é possível, por exemplo, personalizar seu site de acordo com o horário que os usuários menores de 18 anos mais o acessam. 
Segundo Oliveira e Levkowitz (2003), técnicas de exploração visual de dados são destinadas a tirar vantagem da poderosa capacidade visual dos seres humanos e podem ajudar usuários em formular hipóteses úteis sobre os dados. Existem muitas técnicas e categorias de visualização disponíveis e, em vista disso, duas taxonomias foram criadas a fim de classificá-las, sendo elas: a taxonomia de Keim (Keim e Kriegel, 1996) e a taxonomia de Card et al. (Card et al., 1999).

A taxonomia de Keim foi feita com base nas técnicas de visualização e inclui seis classes: projeção geométrica, iconográfica, orientada a pixel, hierárquica, baseada em grafos e híbrida. Dentre elas, pode-se destacar aquelas baseadas em grafos, que serão discutidas na Seção 2.2.1, e correspondem ao tipo de visualização utilizada neste estudo.

A taxonomia de Card et al. categoriza os sistemas de visualizações com base no tipo de dados com que eles lidam e propõe quatro níveis: (1) ferramentas que fornecem ao usuário acesso visual a coleções de informações externas ao seu ambiente imediato, tal como a Internet; (2) ferramentas destinadas a ajudar as pessoas a executarem tarefas rapidamente, permitindo representações visuais interativas sobre o espaço de trabalho da informação, tal como a metáfora de desktops para interfaces gráficas (GUI); (3) ferramentas de conhecimento visual, que descrevem representações visuais dos dados e um conjunto de controles para interagir com tais representações de modo que o usuário possa determinar e extrair relacionamentos dos mesmos. Este nível abrange a maioria das ferramentas destinadas a produzir visualizações de tabelas de dados. Aqui estão inseridas as visualizações de árvores e redes, correspondentes à técnica baseada em grafos, de Keim; (4) ferramentas que melhoram visualmente um objeto para revelar mais informação sobre ele de forma visual intrínseca, por exemplo: a visualização de um órgão humano usando visualização volumétrica para descrever estruturas internas.

O foco do presente estudo, no que diz respeito à visualização de informação, está na visualização baseada em grafos - uma vez que a ferramenta desenvolvida aborda este tipo de dado abstrato e na interação (assuntos discutidos, respectivamente, nas Seções 2.2.1 e 2.2.2). Para conhecer mais detalhes sobre a visualização de informação e seus diversos segmentos recomenda-se a leitura dos trabalhos de Keim e Kriegel (1996), Card et al. (1999) e Oliveira e Levkowitz (2003).

\subsubsection{Visualização baseada em grafos}

Um grafo é um modelo matemático muito utilizado para descrever relacionamentos entre entidades (Nascimento, 2003). Sumariamente, pode-se definir que um grafo $G$ é composto por um conjunto finito de vértices $V$ (as entidades) e um conjunto finito de arestas $E$. As arestas têm a função de conectar os vértices que se relacionam. O número de arestas incidentes em um vértice corresponde ao grau do mesmo. O grafo pode ser dirigido, isto é, as arestas podem possuir uma orientação, sendo representadas por setas. Desta forma, cada vértice possui um grau de entrada e um grau de saída, dependendo da orientação das arestas. Há um grande número de conceitos e definições matemáticas sobre grafos que não serão abordados neste texto, restringindo o tema 
apenas aos algoritmos destinados a realizar o desenho de grafos. Para mais informações sobre a teoria dos grafos, recomenda-se a leitura de Bondy e Murty (1976) e West (2001).

Visualmente, o grafo é uma estrutura muito interessante, pois destaca as relações implícitas presentes em dados estruturados, que é o caso daqueles armazenados em bases de dados. Os algoritmos de desenhos de grafos são bastante utilizados em projetos de design de circuitos VLSI ${ }^{3}$, análise de redes sociais e de transporte, bioinformática, telecomunicações, entre outros. A Figura 2.4 ilustra um exemplo da aplicação de desenho de grafo não-dirigido destinado à análise de redes sociais. Nela, pode-se ver a maior parte da rede de relacionamentos sexuais ocorridos entre os alunos da Jefferson High School entre 1993 e 1995. Rapazes são representados por vértices azuis enquanto garotas são representadas por vértices cor-de-rosa. O contato sexual é representado por arestas. O trabalho de Bearman et al. (2004) visa o estudo das redes de relacionamentos sexuais para modelar a dinâmica de transmissão de DSTs.

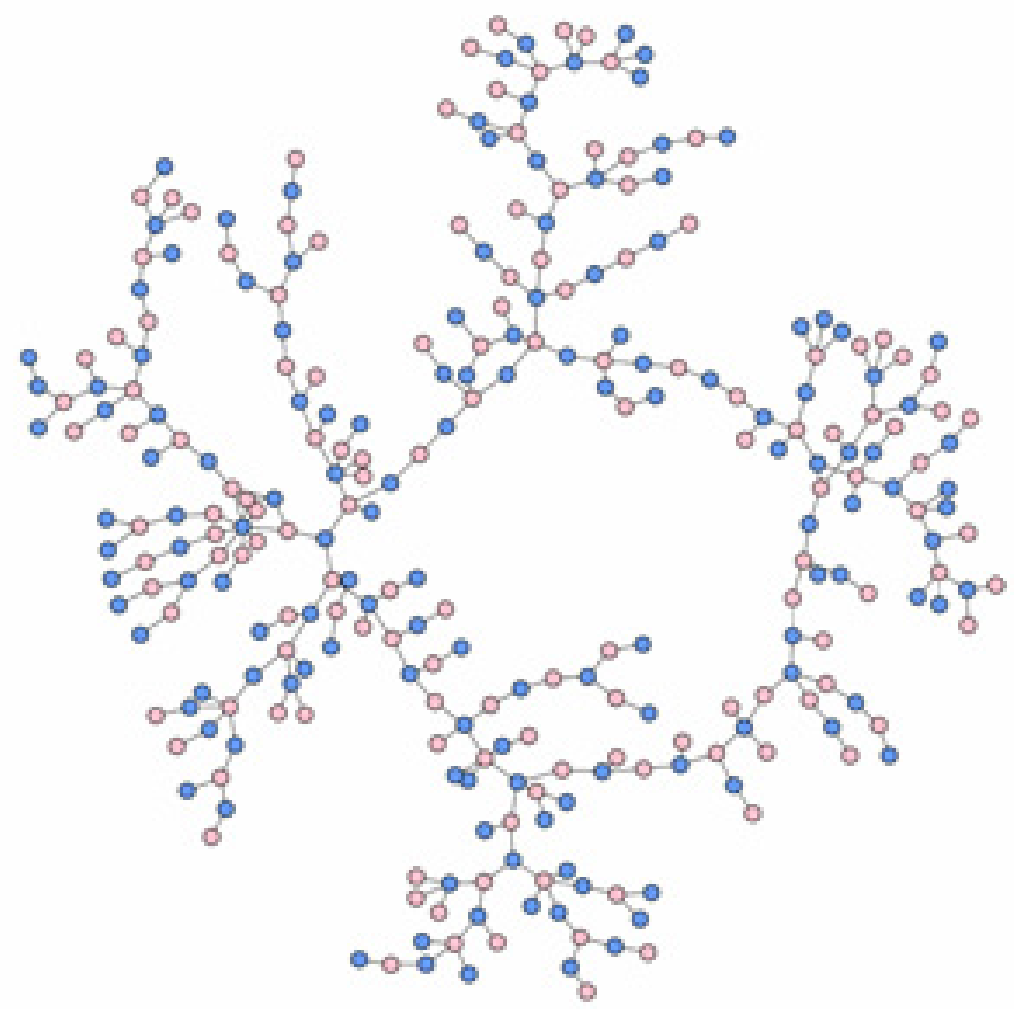

Figura 2.4: Parte da rede de relacionamentos sexuais ocorridos na Jefferson High School no período entre 1993 e 1995. Retirada de Bearman et al. (2004).

Existem diversos algoritmos de desenho de grafos. Isto significa que diferentes desenhos podem representar o mesmo grafo. Entretanto, cada desenho possui um propósito específico como, por exemplo, ressaltar a hierarquia dos dados, revelar grupos formados (clustering) e representar esquemas em 3D. É a disposição dos vértices e das arestas desenhados que influencia diretamente na estética, na compreensão e na utilidade do desenho em relação ao contexto da informação.

\footnotetext{
${ }^{3}$ Circuitos altamente complexos, podendo conter milhares de portas lógicas (Rubin, 1994).
} 
Independentemente do propósito do desenho do grafo, os algoritmos buscam produzir desenhos esteticamente agradáveis. Embora o conceito de estética seja inerentemente subjetivo, critérios estéticos foram criados para avaliar a qualidade dos algoritmos de desenho de grafos e desde então vêm sendo estudados e seguidos. Alguns dos critérios estéticos utilizados para o desenho de grafos são: mostrar um baixo número de cruzamento de arestas, mostrar simetria no desenho, minimizar a área do desenho e minimizar os cotovelos formados ou por arestas curvilíneas ou por desenhos ortogonais. Em geral, é muito difícil otimizar dois critérios simultaneamente, pois ao atender a um critério pode-se prejudicar outro. Por exemplo, durante a tarefa de diminuir o número de cruzamento de arestas pode-se perder um pouco de simetria. Assim, uma maneira de contornar este tipo de problema é fazer algumas concessões para se atingir um meio-termo (Cruz e Tamassia, 2006). Outra maneira é priorizar os critérios mais importantes. Em Purchase (1997) são discutido quais critérios contribuem mais para a compreensão dos desenhos.

Os principais tipos de desenhos para grafos são: baseado em força, orientado a nível, ortogonal e circular, entre outros. A seguir, é dada uma visão geral dos tipos de desenhos de grafos mais relevantes.

\section{Baseado em força}

Os algoritmos baseados em força usam metáforas de fenômenos físicos para dispor desenhos intuitivos ao ser humano. A abordagem mais comumente utilizada é a de fazer com que as arestas simulem o comportamento de molas, se contraindo ou se estendendo devido à força exercida por todo o conjunto, no caso, o grafo. O objetivo disso é ter os vértices separados de maneira mais uniforme e, portanto, disponibilizar um desenho mais "limpo". Com isso, é possível identificar simetrias antes não percebidas. Este tipo de desenho é indicado para grafos complexos e de grande porte, como redes sociais e diagramas de redes de computadores. A Figura 2.5 exemplifica este esquema com molas. No desenho, após algumas iterações, o grafo tende a se auto-ajustar.

Outras alternativas já foram implementadas, como a simulação de um campo magnético entre os vértices, repelindo ou atraindo uns aos outros até que um equilíbrio seja atingido, ou ainda, a simulação de campos gravitacionais. Existem diversos trabalhos relativos aos desenhos baseados em força, sendo que alguns deles são encontrados em Eades (1984), Fruchterman e Reingold (1991), Sugiyama e Misue (1995a,b) e Di Battista et al. (1998). No Capítulo 4 é apresentada a ferramenta TouchGraph, que trabalha com este tipo de algoritmo e foi utilizada como base para a implementação da ferramenta produzida neste estudo.

\section{Orientado a nível}

Este tipo de desenho é geralmente utilizado em grafos dirigidos. Segundo Sugiyama et al. (1981), esta abordagem contém três passos: (1) inicialmente, os vértices são distribuídos em camadas horizontais, onde os vértices com maior grau de saída (número de arestas que saem de um vértice) ficam nos níveis superiores enquanto os vértices com menor grau de saída ficam nos níveis 

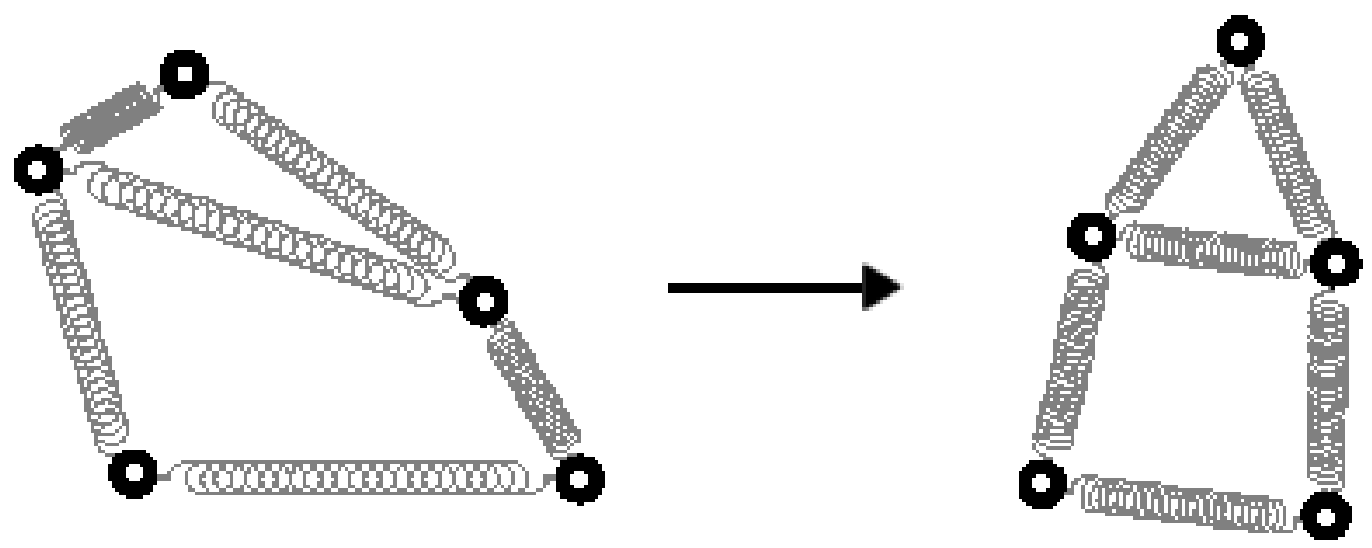

Figura 2.5: Desenho do tipo baseado em força utilizando a metáfora de molas. Retirada de Cruz e Tamassia (2006).

inferiores e deve-se garantir que os vértices no mesmo nível não possuam arestas entre si; (2) o segundo passo é minimizar o cruzamento entre as arestas; (3) por último, cada vértice é ajustado com a coordenada horizontal para minimizar o comprimento das arestas, sem mudar a disposição conseguida anteriormente. A Figura 2.6 ilustra como ficaria um desenho depois da realização dos três passos descritos.

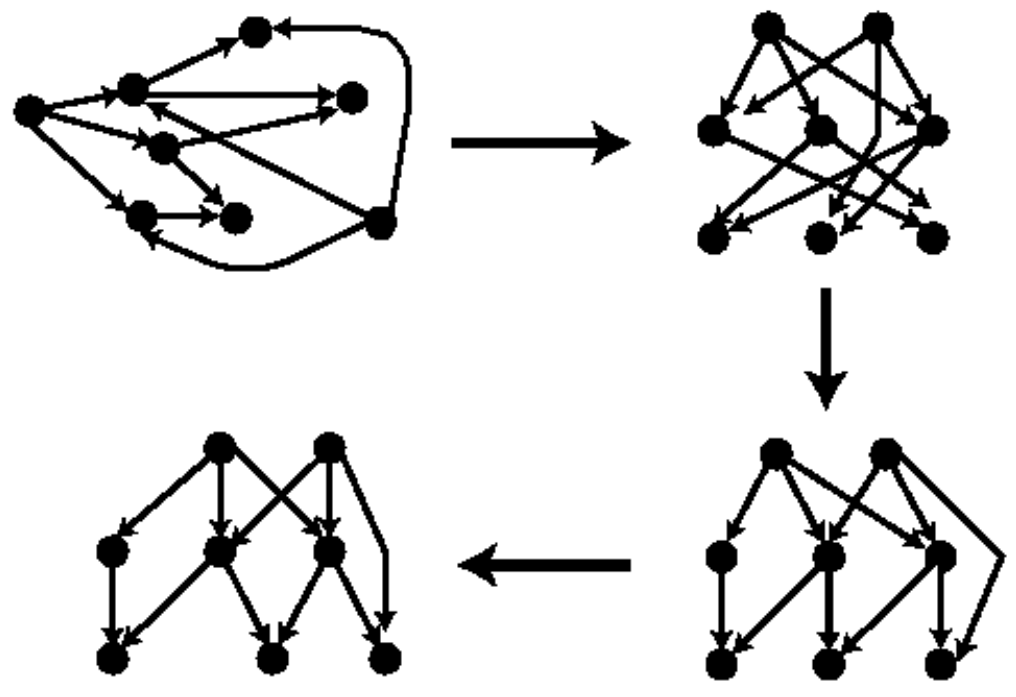

Figura 2.6: Passos utilizados pelos algoritmos de desenho oritentado a nível. Retirada de Niggemann (2002)

As vantagens desta técnica são a visualização intuitiva conseguida para grafos com muitas arestas na mesma direção e a extração natural de alguma hierarquia dos dados. Para grafos nãodirigidos, pode-se atribuir aleatoriamente direções para as arestas, mas isso mudaria a natureza do 
grafo e afetaria em sua visualização. Mais detalhes deste tipo de desenho podem ser encontrados em Sander (1994) e Di Battista et al. (1998).

\section{Ortogonal}

Este tipo de desenho dispõe as arestas sempre paralelas ou perpendiculares em relação aos eixos $x$ e $y$ do plano cartesiano (para 2D), permitindo a existência de cotovelos (bends) nas arestas. Entretanto, é comum que se busque o mínimo possível de cotovelos para deixar o desenho menos complexo. Os desenhos produzidos por esta abordagem para grafos muito densos não são muito intuitivos ao ser humano, porém são amplamente utilizados em projetos de design de circuitos VLSI. A Figura 2.7 ilustra um desenho feito com este tipo de algoritmo. Outros detalhes deste tipo de desenho podem ser encontrados em Tamassia e Tollis (1989) e Papakostas e Tollis (1998).

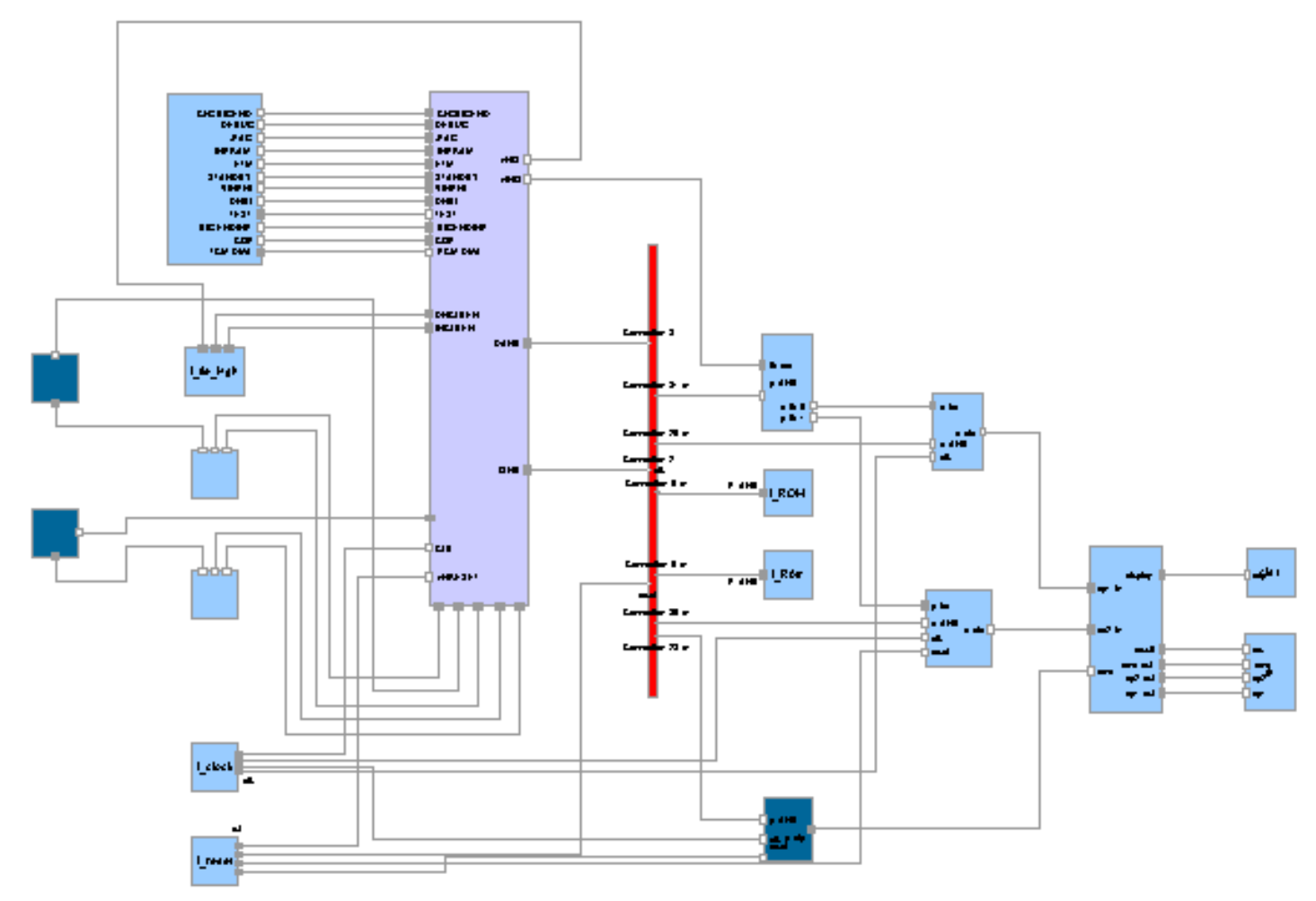

Figura 2.7: Diagrama da arquitetura de um circuito produzido por um algoritmo de desenho ortogonal. Retirada de Tom Sawyer Software (2006).

\section{Circular}

Este tipo de desenho é geralmente utilizado para enfatizar agrupamentos entre os vértices. Tais agrupamentos são úteis, por exemplo, na administração de redes de computadores, na análise de redes sociais e na visualização de um comércio eletrônico. A Figura 2.8 ilustra uma rede de computadores. Outros detalhes deste tipo de desenho, como a redução do número de cruzamentos entre arestas, podem ser encontrados em Six e Tollis (1999) e Baur e Brandes (2004). 


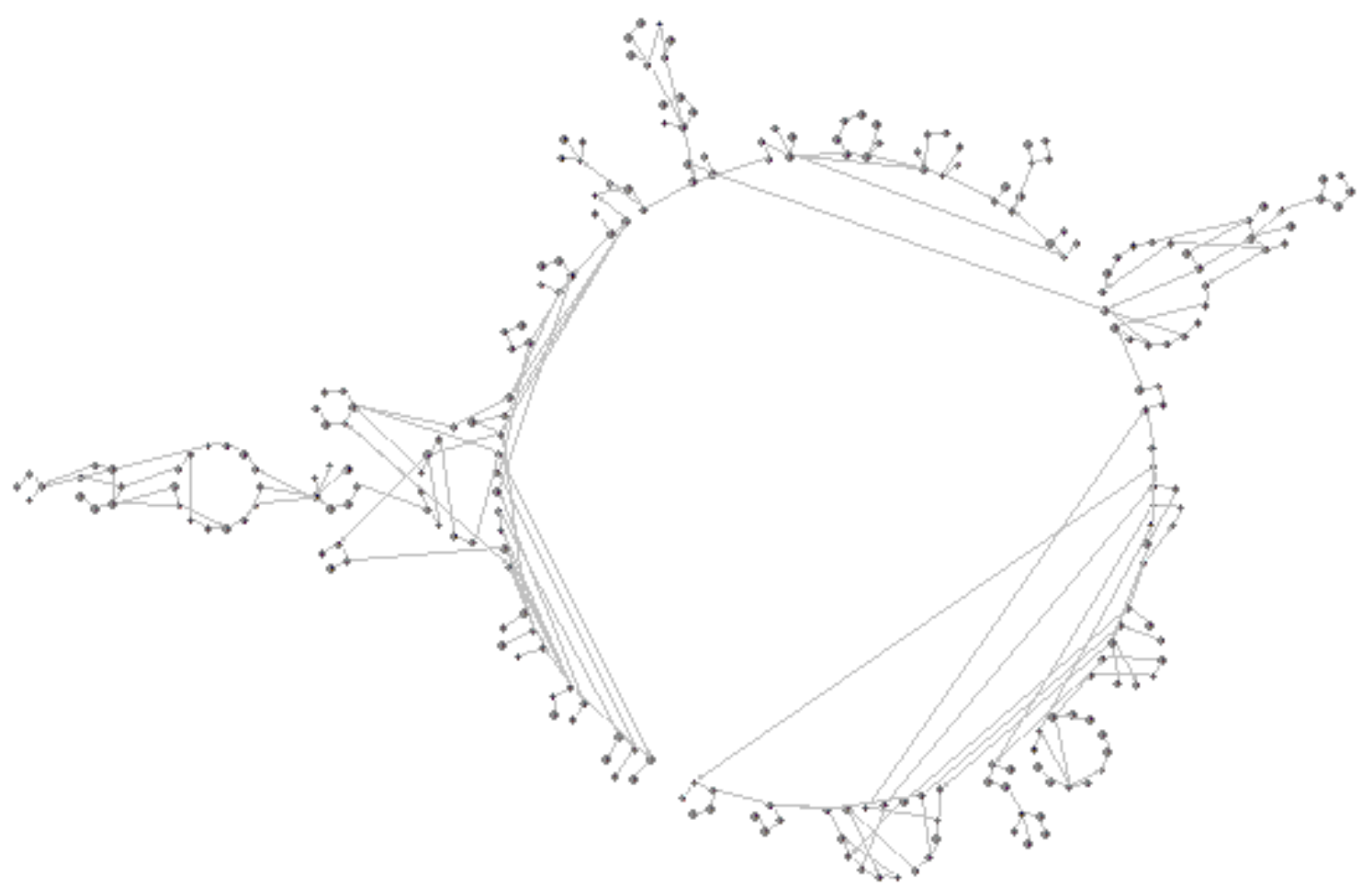

Figura 2.8: Desenho de uma rede de computadores produzido por um algoritmo de desenho circular. Retirada de Tom Sawyer Software (2006).

\section{Outros desenhos}

Além dos tipos de desenhos descritos anteriormente, há ainda outros, tais como: desenhos combinados com clustering e desenhos $3 \mathrm{D}^{4}$. O primeiro é destinado a ressaltar agrupamentos a partir das imagens geradas pelos algoritmos de desenhos citados. Uma boa forma de fazer isso é com a utilização de polígonos que englobem determinados vértices para caracterizar os agrupamentos (Feng et al., 1995; Sander, 1996). Já a teoria em torno dos desenhos em 3D possui duas vertentes: a generalização das técnicas clássicas em $2 \mathrm{D}$ para desenhos em $3 \mathrm{D}$, como acontece com o desenho ortogonal com extensão para 3D (Cohen et al., 1997; Eades et al., 2000); e algoritmos diretamente desenvolvidos para três dimensões, como as conhecidas cone trees de Robertson et al. (1993), que destacam a hierarquia de sistemas de arquivos.

\subsubsection{Interação}

As técnicas de interação desempenham um papel fundamental dentro da área de visualização de informação, aumentando o poder de percepção humana sobre um conjunto de dados durante a exploração visual (Hibbard et al., 1995). Virtualmente, todas as técnicas de visualização são combinadas com a dinâmica e a interatividade. Ainda, a habilidade em interagir com representações

\footnotetext{
${ }^{4}$ Herman et al. (2000) fazem um levantamento abrangente destes e outros tipos de desenhos de grafos.
} 
visuais pode reduzir drasticamente os pontos fracos apresentados pelos tipos de visualização, particularmente aqueles ligados à confusão visual e à sobreposição de objetos na imagem, fornecendo ao usuário mecanismos para lidar com a alta complexidade de grandes conjuntos de dados (Oliveira e Levkowitz, 2003).

Keim $(2001,2002)$ identifica duas categorias de técnicas de interação. A primeira é composta por aquelas que agem nas representações visuais para permitir a visualização de uma quantidade maior de dados, distorcendo a imagem e, por isso, chamadas de técnicas de distorção. A idéia básica destas técnicas é mostrar porções dos dados em um nível maior de detalhes enquanto outras são mostradas com um nível menor de detalhes, mas sempre mantendo uma visão geral sobre o conjunto de dados. Muitas destas técnicas trabalham em domínios específicos e podem ser consideradas como técnicas de visualização, como as árvores hiperbólicas (Lamping e Rao, 1996) e as visões olho-de-peixe (Sarkar e Brown, 1994; Formella e Keller, 1995). As árvores hiperbólicas dispõem uma árvore em um círculo e posiciona em seu centro uma região de interesse para o usuário (ver Figura 2.9). Esta região muda dinamicamente pelo simples clique do mouse. As visões olho-de-peixe aumentam uma área de interesse, ao passo que, simultaneamente, mostram menos detalhes de outras porções da imagem (ver Figura 2.10).

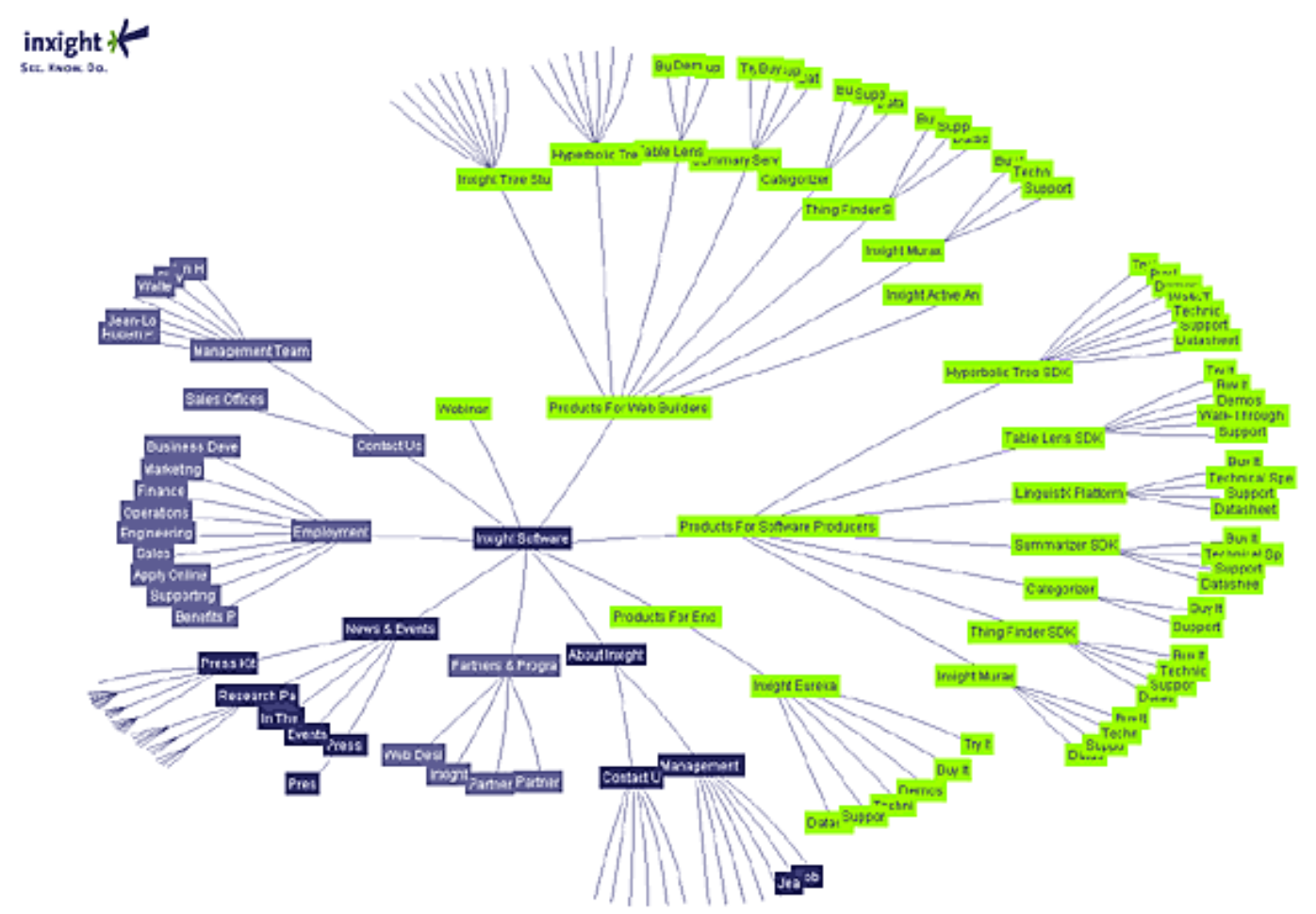

Figura 2.9: Mapeamento de um site através de uma árvore hiperbólica, com temas destacados por cores. Retirada de Inxight (2006).

A segunda categoria é composta por técnicas que auxiliam uma exploração mais efetiva, permitindo que o usuário faça mudanças dinâmicas diretamente com a visualização de acordo com os objetivos da exploração, como zooming, filtragem, detalhes sob demanda e linking-and- 


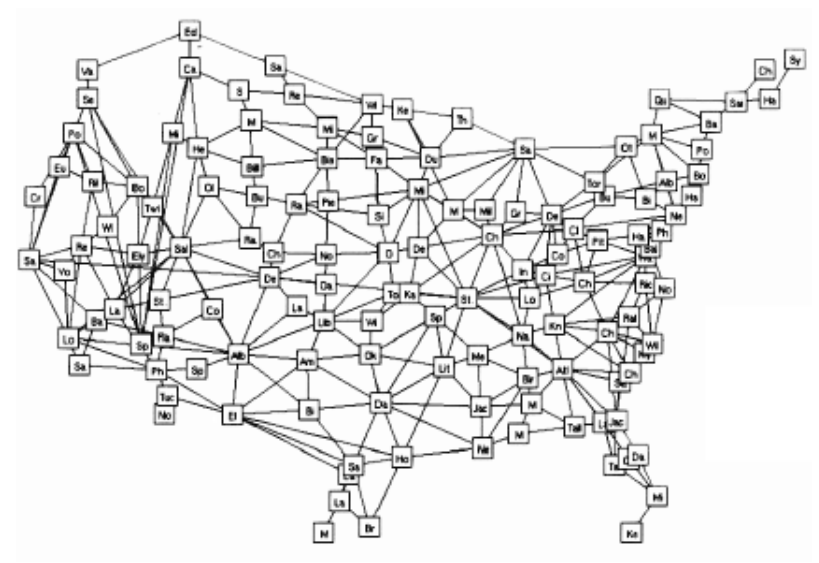

(a)

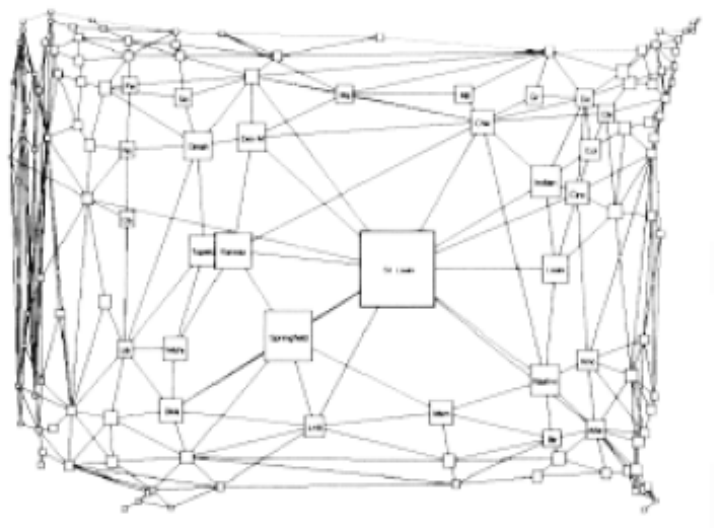

(b)

Figura 2.10: (a) Grafo representando os EUA, onde os vértices representam as suas maiores cidades e as arestas representam estradas entre cidades vizinhas. (b) Mesmo grafo sob efeito das visões olho-de-peixe. A cidade com maior destaque é St. Louis. Retirada de Sarkar e Brown (1994).

brushing. O zooming é uma técnica tradicional de interação que não somente aumenta os objetos da tela, mas também possibilita mudanças automáticas na representação dos dados para apresentar mais detalhes em um nível maior de zoom. A filtragem pode ser feita por meio de consultas dinâmicas a uma base de dados através de uma interface contendo, por exemplo, botões e barras de rolagem, enquanto os resultados são simultaneamente modificados na tela (Shneiderman, 1994). A técnica de detalhes sob demanda trabalha em cima de dados previamente triados e, portanto, fáceis de serem inspecionados individualmente. Um bom exemplo é o simples clique do mouse em um item para abrir um pop-up com informações dos seus atributos (Shneiderman, 1996). O linking-and-brushing propõe múltiplas e diferentes visualizações do mesmo conjunto de dados e modificações feitas em uma delas refletem automaticamente nas outras (Keim, 2002).

As técnicas de visualização aliadas às técnicas de interação produziram vários sistemas de exploração visual de dados, dentre eles pode-se destacar as ferramentas acadêmicas XmdvTool (Ward, 1994), XGobi (Swayne et al., 1998), Polaris (Stolte et al., 2002) e as ferramentas comerciais IVEE/SpotFire (Ahlberg e Wistrand, 1995) e Inxight (Inxight, 2006). Chuah e Roth (1996) estabelecem bases de comparação entre diferentes sistemas, reuso de elementos de arquiteturas anteriores e composição de primitivas de interação para criar novas interfaces. Várias das técnicas de interação descritas nesta seção foram utilizadas no presente estudo e serão assinaladas nos Capítulos 4 e 5 . 


\subsection{Visualização aliada à bioinformática}

Desde o seu início, a bioinformática vem buscando formas de visualizar as informações extraídas da biologia molecular. Inicialmente, os tipos de visualizações permitiam pouca interatividade devido à grande quantidade de dados obtidos e ao pouco poder de processamento dos computadores. Com o avanço da tecnologia empregada nos computadores somada ao desenvolvimento de novos algoritmos foi possível processar tais dados mais rapidamente e, com isso, aumentar a qualidade e a interatividade das ferramentas visuais, permitindo que tarefas antes realizadas em dias fossem realizadas em segundos.

A Figura 2.11 ilustra a forma como este estudo aborda a visualização na bioinformática. $\mathrm{O}$ primeiro passo é a transformação - em laboratório - de dados genéticos brutos em dados que sirvam de entrada para ferramentas de bioinformática (ver Capítulo 3). O segundo passo é o processamento destes dados com as ferramentas de bioinformática para gerar uma entrada para uma ferramenta de visualização. O terceiro passo é a visualização com a utilização de dispositivos dinâmicos de interação para permitir que o usuário explore facilmente o conjunto de dados.

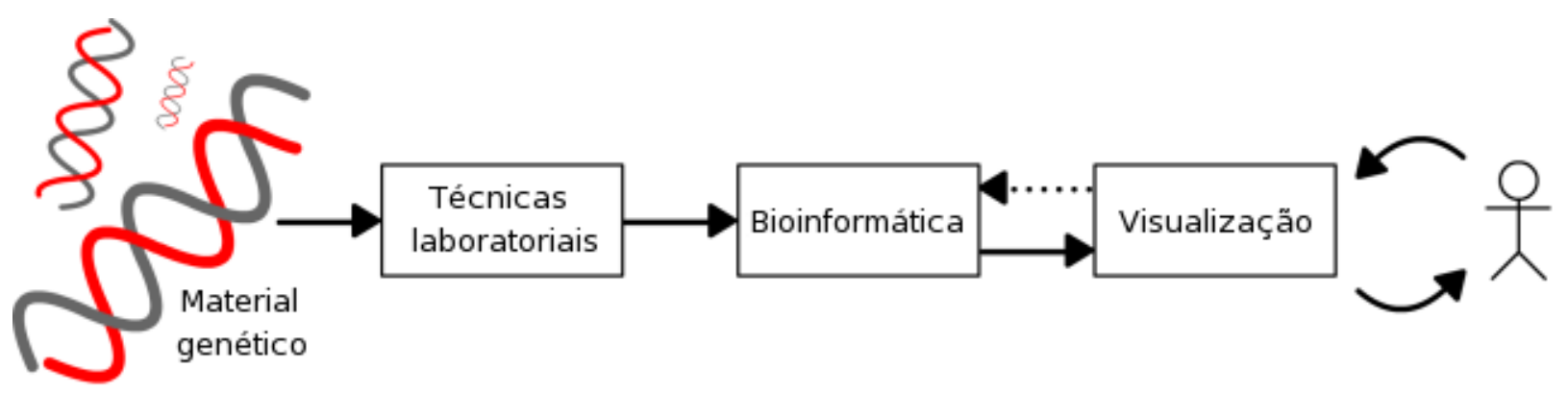

Figura 2.11: Etapas existentes desde a obtenção dos dados até sua apresentação visual. As setas curvas indicam o processo interativo de visualização, enquanto a seta tracejada indica que, mesmo durante a visualização, algumas requisições às ferramentas de bioinformática podem ocorrer.

\subsubsection{Trabalhos relacionados}

Nesta seção são apresentadas algumas ferramentas de visualização destinadas a dados genéticos. Os dois principais tipos de dados tratados por estas ferramentas são seqüências de DNA e de proteínas. Em geral, as ferramenta de visualização são específicas para trabalharem com um destes tipos. Os exemplos são apenas uma pequena amostragem das ferramentas disponíveis.

Schneider e Stephens (1990) descrevem o método sequence logos de apresentar as bases de um conjunto de sequiências alinhadas, determinando sua sequiência consenso (ver Capítulo 3). As letras correspondentes a cada base de uma seqüência possuem uma altura proporcional à freqüência com que elas ocorrem numa determinada posição. Por exemplo, se a base $\mathrm{C}$ (citosina) ocorre dez vezes em uma posição da seqüência enquanto a base $\mathrm{T}$ (timina) ocorre apenas uma na mesma posição, então a letra $\mathrm{C}$ aparecerá mais esticada do que a letra $\mathrm{T}$ nesta posição. As letras com 
maior freqüência ainda aparecem acima das demais. Qualquer conjunto alinhado de seqüências de DNA, RNA ou proteína pode ser representado por esta técnica. A Figura 2.12 ilustra a visualização de uma sequiência consenso através do método descrito.

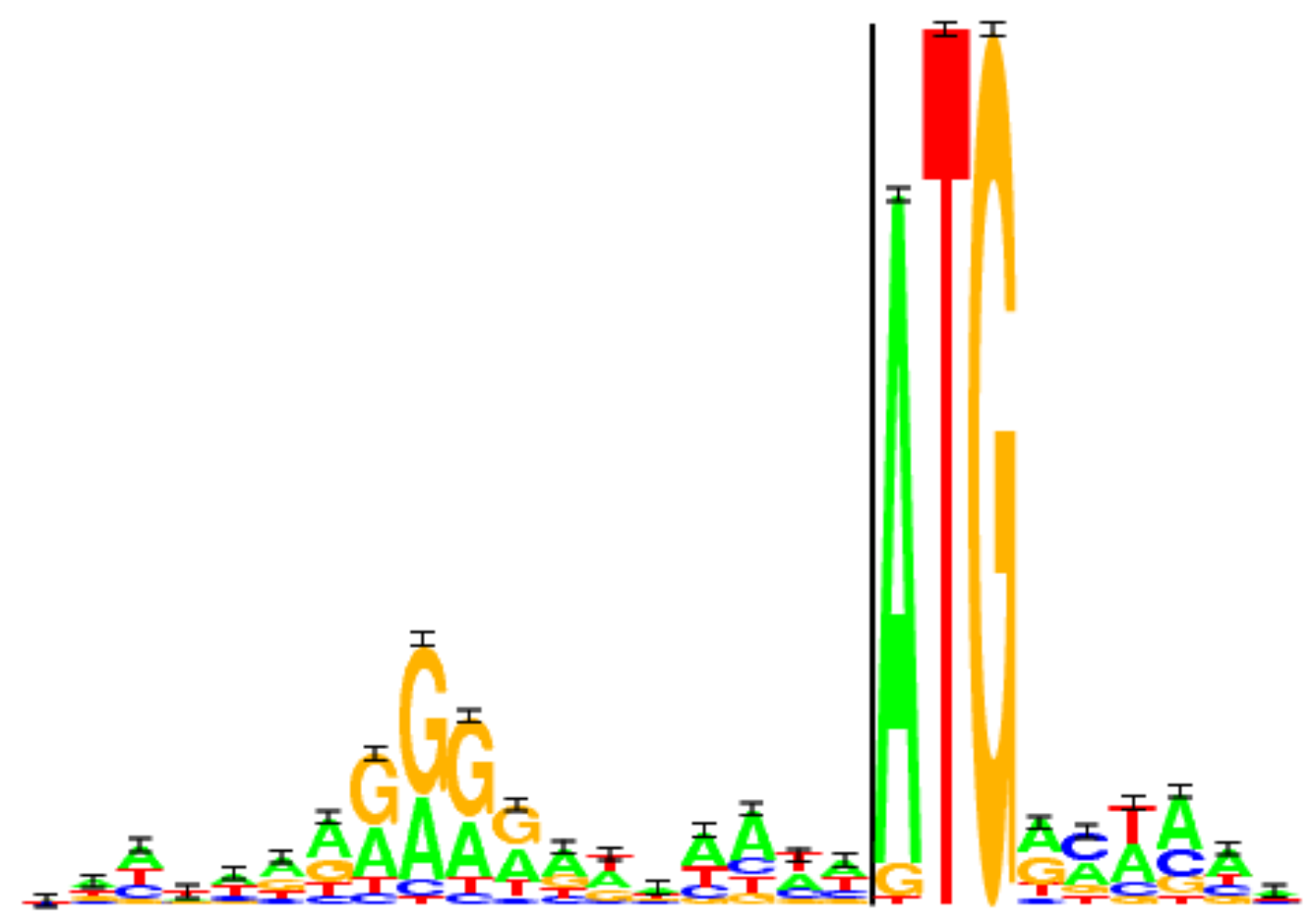

Figura 2.12: Visualização do trecho de uma seqüência consenso pelo método sequence logos. As letras que estão mais acima representam quais são as bases escolhidas para aquelas posições da sequiência. Foram utilizados 149 trechos de sequiências para criar este logo. Retirada de Schneider e Stephens (1990).

O STING ${ }^{5}$ (Neshich et al., 1998) é um programa criado por pesquisadores da Embrapa em conjunto com pesquisadores de universidades nacionais e internacionais para o estudo de interações entre proteínas. Disponibilizado na Web, ele atingiu grande aceitação sendo que, em 2001, pouco mais de dois anos depois do seu lançamento, já havia sido acessado por mais de 5 milhões de usuários (Gerhardt, 2001). A principal característica do programa é relacionar uma seqüência de proteína em forma de texto com sua estrutura em 3D, dispostas em suas duas janelas principais. Além disso, várias ferramentas de interação estão à disposição do usuário. A Figura 2.13 demonstra a ferramenta STING, onde a janela superior traz a seqüência enquanto a janela inferior traz sua estrutura em 3D.

Becker e Rojas (2001) descrevem uma ferramenta para a visualização de caminhos metabólicos, que são uma série de reações químicas que ocorrem dentro de uma célula, catalizadas por enzimas, resultando em produto útil para a célula. É comum que caminhos metabólicos sejam modelados como sistemas complexos, onde vértices significam compostos químicos e arestas são as reações entre os compostos. O algoritmo de desenho de grafo utilizado por eles combina os

${ }^{5}$ Disponível em http://www.cbi.cnptia.embrapa.br/SMS/index_s.html. 


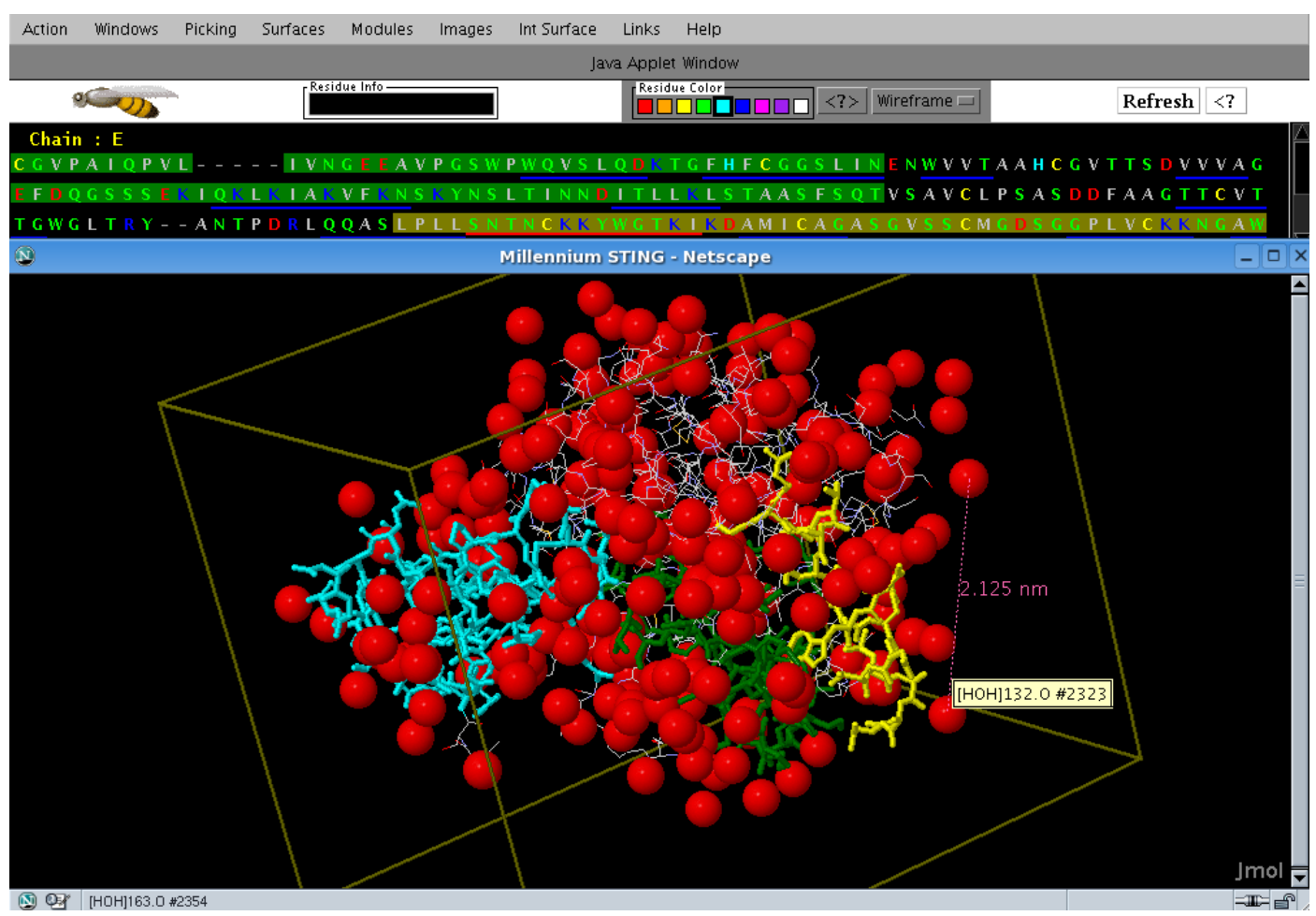

Figura 2.13: Visualização da seqüência e da estrutura de uma molécula com a ferramenta STING.

desenhos dos tipos circular, hierárquico e baseado em força (ver Seção 2.2.1) para destacar as posições dos elementos do grafo representando os principais compostos e reações.

Heber et al. (2002) descrevem uma técnica para a visualização de combinações variantes de ESTs, pois um gene pode dar origem a diferentes ESTs (ver Capítulo 3). A visualização é feita através de um grafo dirigido contendo vários caminhos, sendo que cada caminho representa um diferente transcrito. Os vértices deste grafo representam as bases comuns entre os transcritos. Esta técnica propõe uma alternativa em relação às abordagens tradicionais, que investigavam, caso-acaso, as combinações dos ESTs originados de um único gene. A Figura 2.14 ilustra a técnica de visualização de combinações variantes de ESTs.

Há diversos outros trabalhos de visualização aliada à bioinformática para os mais diferentes propósitos. Alguns deles podem ser encontrados no Instituto para Pesquisa Genômica ou no Centro Nacional para Informação em Biotecnologia, respectivamente $\mathrm{TIGR}^{6} \mathrm{e} \mathrm{NCBI}^{7}$, nas siglas em inglês. O objetivo da amostra apresentada aqui é ilustrar as variedades de ferramentas disponíveis.

\footnotetext{
${ }^{6}$ http: //www.tigr.org/

${ }^{7}$ http://www.ncbi.nlm.nih.gov/
} 


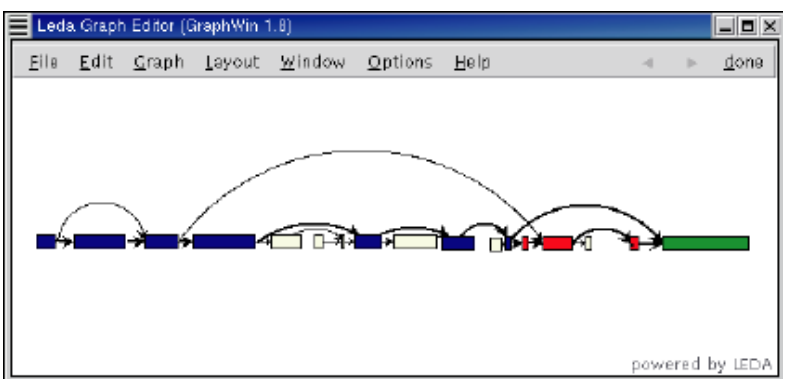

(a)

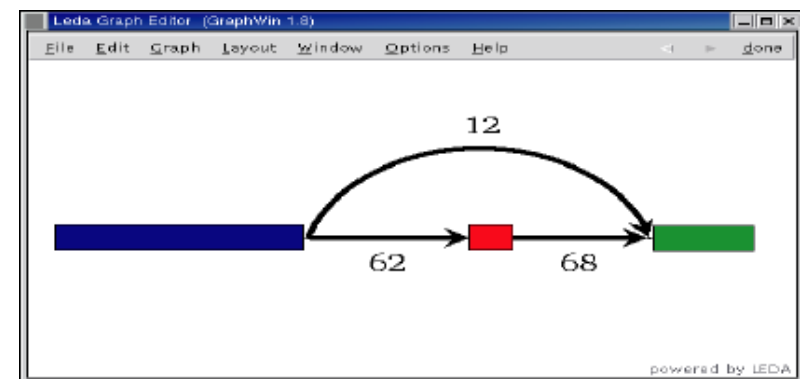

(b)

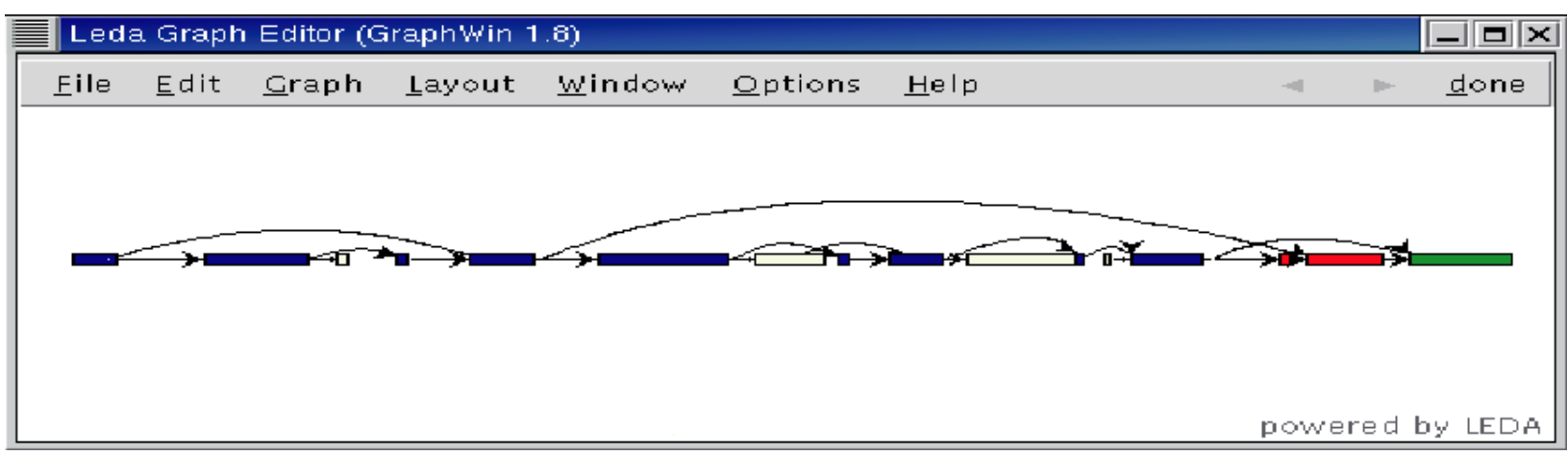

(c)

Figura 2.14: (a) Grafo do cluster Hs.75527 da base UniGene. (b) O mesmo grafo reduzido a apenas 3 partes devido à remoção das bifurcações que só acontecem para um pequeno número de ESTs. Os números sobre as arestas indicam a quantidade de ESTs que cada caminho possui. (c) O mesmo grafo especificado e com erros corrigidos. Retirada de Heber et al. (2002).

\subsection{Considerações finais}

Este capítulo fez um levantamento das áreas fundamentais para o desenvolvimento deste trabalho: bioinformática, visualização de informação e a união delas. Com isso, é possível estender este estudo a partir do que foi descrito e, junto com conceitos da biologia molecular (ver Capítulo 3), mostrar a metodologia adotada para a construção da ferramenta de visualização.

Dentro da metodologia deste estudo, aplicam-se algumas ferramentas de bioinformática, tais como o algoritmo de alinhamento BLAST e o montador CAP3, além de scripts escritos na linguagem Perl, amplamente utilizada na bioinformática por se tratar de uma linguagem que possibilita a fácil manipulação de cadeias de caracteres. No âmbito da visualização, buscou-se uma ferramenta de código aberto que já disponibilizasse uma interface agradável com alguns recursos de interação. A ferramenta TG WikiBrowser atendia a esses pré-requisitos e, portanto, serviu de base para a nova ferramenta desenvolvida. Algumas funcionalidades não desejadas foram retiradas e outras foram incorporadas para servir aos propósitos deste estudo.

Em relação aos dados, sabe-se que muitos deles podem ser facilmente transformados em grafos. O mesmo se verifica para dados genéticos. Desta forma, é possível visualizar tais dados e alguns de seus relacionamentos através das ferramentas de visualização em grafos. No próximo capítulo é 
descrito como os ESTs - trechos de genes - são obtidos através de técnicas laboratoriais. Para isso, é feita uma pequena introdução à biologia molecular. Os ESTs são então pré-processados para que sejam mapeados como um grafo antes dele servir de entrada para a ferramenta de visualização concebida. 


\section{Expressed Sequence Tags}

Este capítulo traz conceitos de biologia molecular para explicar a origem dos dados trabalhados neste estudo: os ESTs. ESTs ou rótulos de seqüências expressas (Expressed Sequence Tags, em inglês) são amostras de moléculas geradoras de proteínas extraídas das células de um organismo (Adams et al., 1991). Antes de mostrar como os ESTs são obtidos em laboratório, é necessária uma pequena introdução à biologia molecular, descrevendo conceitos básicos e processos intracelulares, como a estrutura de um gene, o processo de transcrição e algumas funções do RNA. A Seção 3.1 descreve alguns conceitos sobre processos intracelulares que ocorrem com o DNA. A Seção 3.2 apresenta algumas definições importantes antes de abordar a técnica de obtenção dos ESTs. A Seção 3.3 mostra, passo-a-passo, como é feito o seqüenciamento de ESTs em laboratório.

\subsection{Visão geral}

As células são unidades vitais e nelas está contido o material genético (DNA). As células de eucariotos, foco de nosso estudo, são caracterizadas por duas regiões: o citoplasma e o núcleo, onde reside o DNA (ver definição no Capítulo 2). Representativamente, o DNA pode ser descrito por duas cadeias longas contendo seqüências das letras A, C, G e T, com suas pontas representadas pelos símbolos 3' e 5'. A letra A de uma cadeia é complementar à letra T da outra, enquanto a letra $\mathrm{C}$ de uma cadeia é complementar à letra $\mathrm{G}$ da outra e vice-versa. Do mesmo modo, uma ponta 3' de uma cadeia é complementar à ponta 5' da outra. Assim, para um DNA fita dupla, a quantidade de $\mathrm{A}$ é sempre igual à quantidade de $\mathrm{T}(\mathrm{A}=\mathrm{T})$ e a quantidade de $\mathrm{C}$ é sempre igual à quantidade de $\mathrm{G}(\mathrm{C}=\mathrm{G})$. $\mathrm{O}$ exemplo a seguir exemplifica esta representação: 


\section{5' ...ACCGTTGGCAACGT... 3' \\ 3' ...TGGCAACCGTTGCA... 5'.}

O genoma de um ser vivo compreende toda a informação genética do organismo, codificada no seu DNA. Dentro do DNA, existem pequenos trechos chamados genes que são responsáveis pela determinação dos traços hereditários dos organismos vivos. Os genes correspondem a cerca de $5 \%$ de todo o código do DNA, sendo que o restante ( $95 \%)$ é a parte não codificadora, útil para a análise de filogenia mas que tem sua função ainda sob investigação. Os genes dão origem às proteínas, servindo como moldes em um processo chamado transcrição. Isto acontece quando as fitas do DNA que compreendem um gene se desligam, permitindo que uma fita de RNA copie o código de uma fita do DNA. As três regiões constituintes de um gene são: o promotor, a região codificadora (formada por íntrons e éxons) e o terminador (ver Figura 3.1).

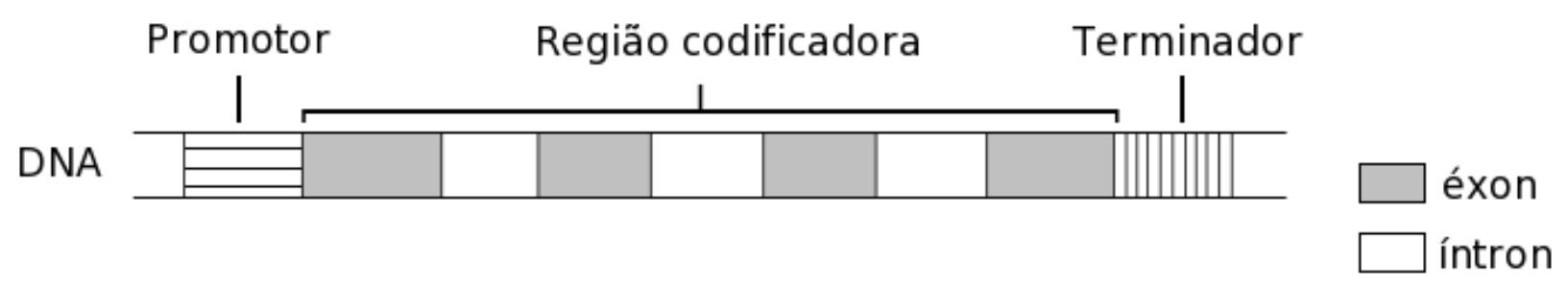

Figura 3.1: Regiões de um gene.

A transcrição é o processo de decodificação da mensagem contida em um gene para uma fita de RNA, que por sua vez leva este código para ser traduzido em proteínas. As proteínas são moléculas que têm várias funções e estão envolvidas em quase todos os processos dentro de uma célula como, por exemplo: reprodução, respiração, defesa e movimentação. No início do processo de transcrição, uma enzima RNA polimerase reconhece a sequiência do promotor do gene e se liga a ela, dando início à síntese da molécula de mRNA (RNA mensageiro), como pode ser visto na Figura 3.2. Desta forma, o promotor é responsável pela ativação do gene, a região codificadora contém a informação usada para sintetizar proteínas e o terminador sinaliza o final da síntese da molécula de mRNA. O RNA é uma molécula fita simples que, assim como uma fita do DNA, pode ser visto como uma seqüência de bases. No entanto, o RNA não possui a base timina (T) e sim a base uracila (U) complementando a base A. Assim, no processo de transcrição, as bases U do RNA se ligam às bases A da fita do DNA.

Após o processo de transcrição, o mRNA sofre transformações (ver Figura 3.3) antes de ser transportado do núcleo para o citoplasma da célula, onde ocorre o processo de tradução. Dentre as transformações, há a adição de 100 a 250 bases do tipo A no final de um ou mais éxons. Esta região é chamada de poli-A. Além disso, todos os íntrons e alguns éxons são removidos do mRNA, ou seja, os íntrons são partes não codificadoras de proteínas dentro do gene. A remoção de alguns éxons permite que um gene dê origem a diferentes proteínas, pois os éxons removidos em um processo podem ser mantidos em outros, assim como éxons mantidos neste podem ser 


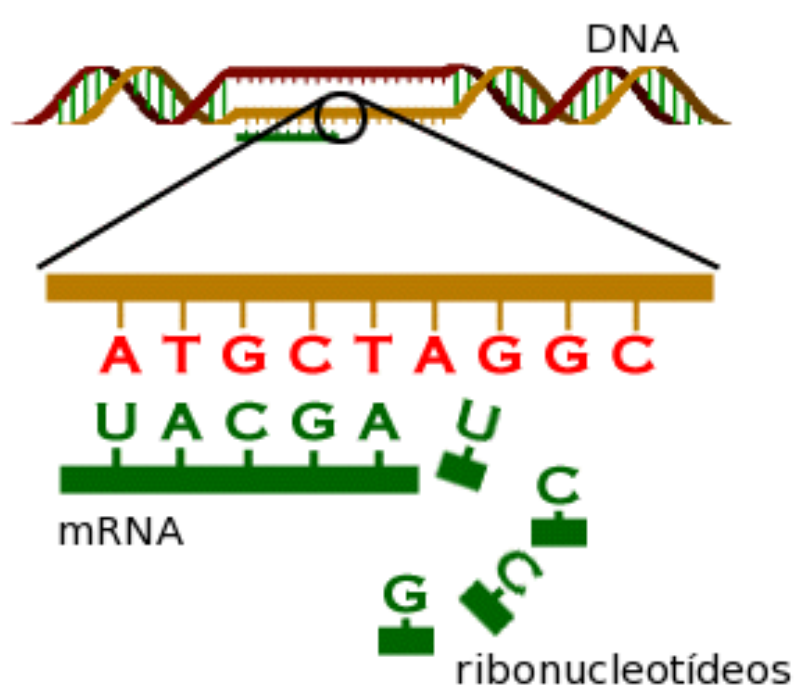

Figura 3.2: Processo de transcrição. Retirada de Brooklyn College (2006).

removidos em outros. Normalmente, o primeiro éxon seguido por uma região poli-A é o último que permanece no mRNA. Após as transformações, os mRNAs são ditos transcritos.

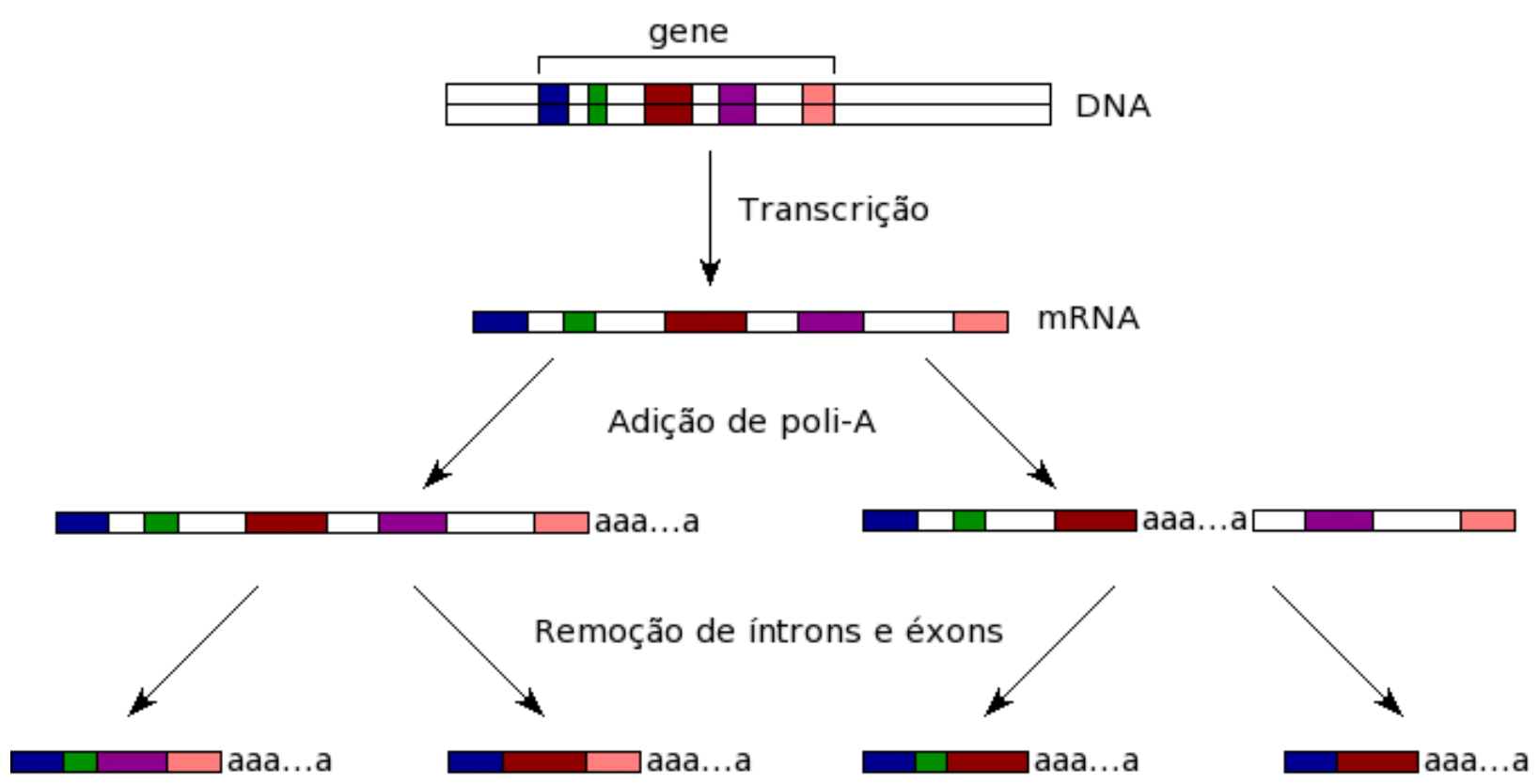

Figura 3.3: Sequiência de transformações na célula para a construção de transcritos a partir de um gene. Retirada de Telles (2002).

Os transcritos são então transportados até o citoplasma para realizar a tradução. A tradução é o processo que traduz o código contido nos transcritos em proteínas. A cada três bases - ou códon - do transcrito é associado um aminoácido para formar uma cadeia de aminoácidos, que constitui uma proteína. O processo continua até que um códon de parada do transcrito seja atingido. Os ESTs são obtidos antes que os transcritos sofram a tradução. 
Os processos intracelulares descritos até este momento são necessários para a obtenção de transcritos como matéria-prima para a produção de ESTs. Estes processos não sofrem interferência humana. Agora, para aumentar a amostra dos transcritos e consequientemente dos ESTs, aplicamse uma série de técnicas laboratoriais. Antes disso, precisamos definir alguns termos relativos a estruturas utilizadas por estas técnicas. Estes termos são apresentados na seção seguinte.

\subsection{Definições importantes}

Esta seção apresenta algumas definições relativas a estruturas utilizadas no processo laboratorial de replicação dos transcritos produzidos no interior da célula.

Sítio de restrição é uma região onde o DNA pode ser cortado por uma enzima de restrição. Uma enzima de restrição reconhece trechos de seqüências de DNA fita dupla com tamanho variando entre 4 a 8 bases e os corta em um lugar específico. Por exemplo, a enzima EcoRI reconhece o trecho GAATTC e faz um corte entre as bases $\mathrm{G}$ e A, deixando duas pontas livres, como pode ser visto no exemplo a seguir:

Antes da enzima de restrição.

Após a enzima de restrição.

$$
\begin{aligned}
& \text { 5' ...GAATTC... 3' } \\
& 5 \text { '...G } \\
& \text { AATTC... 3' } \\
& \text { 3' ...CTTAAG... 5' } \\
& \text { 3' ...CTTAA } \\
& \text { G... 5'. }
\end{aligned}
$$

Sequiência adaptadora é uma seqüência curta de DNA que possui um sítio de restrição.

Vetor de clonagem é uma molécula de DNA em forma de anel na qual um DNA estrangeiro pode ser inserido, tal que este novo DNA possa ser replicado como se fizesse parte do DNA do próprio vetor. Ele ainda possui, entre outras coisas, sítios de restrição (normalmente os mesmos das seqüências adaptadoras) e um gene que confere resistência a antibióticos.

Inserto é o nome dado à inserção de um trecho de DNA em um vetor de clonagem. Quando mais de um inserto ocorre dentro de um mesmo vetor chamamos de inserto quimérico.

Estas e outras definições podem ser encontradas em Voet e Voet (1995) e Stansfield et al. (1996). A próxima seção descreve os passos para a produção e o seqüenciamento de ESTs utilizando as estruturas descritas nesta seção.

\subsection{Seqüenciamento de ESTs}

Esta seção apresenta uma série de técnicas laboratoriais utilizadas até a obtenção dos ESTs. As técnicas são descritas nos seguintes passos:

- As células são preparadas em cultura, rompidas e o material resultante passa por filtragem e lavagem. Boa parte dos RNAs que possuem regiões poli-A são separados, pois correspondem aos trancritos mostrados na Seção 3.1; 
- Os RNAs são processados por enzimas e reagentes para se transformarem em moléculas híbridas que possuem, cada uma, uma fita de RNA e outra correspondente de DNA. O RNA é então degradado, restando apenas DNA fita simples para depois produzir o DNA fita dupla. Este DNA tem sequiência equivalente a do RNA e é chamado de DNA complementar (cDNA), como pode ser visto na Figura 3.4;

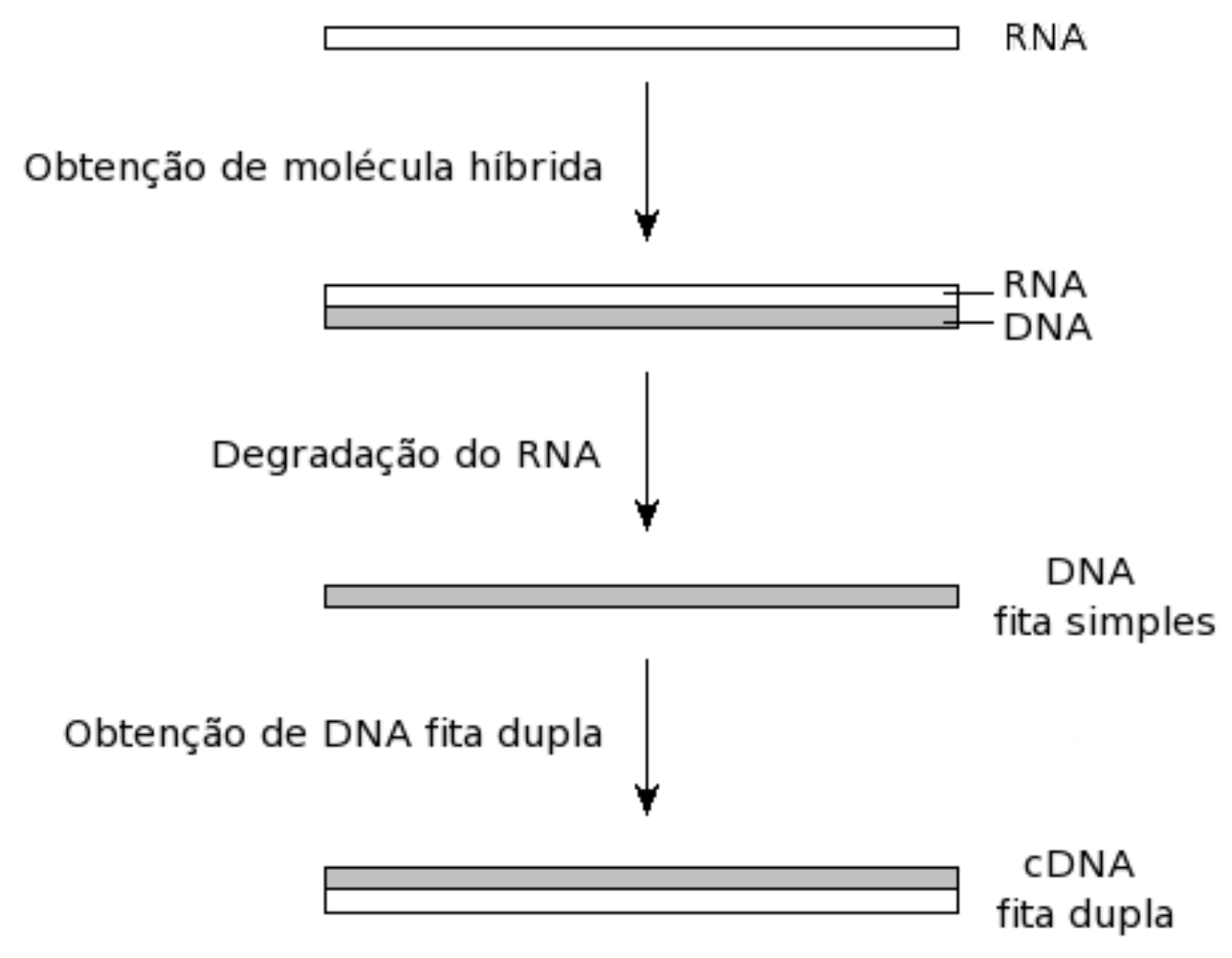

Figura 3.4: Obtenção do DNA fita dupla a partir do RNA.

- Uma reação adiciona seqüências adaptadoras às duas pontas do cDNA (ver Figura 3.5);

- As moléculas de DNA com seqüências adaptadoras são colocadas em solução juntamente com vetores de clonagem;

- Duas enzimas de restrição são adicionadas à solução para cortarem os vetores e os DNAs nos sítios de restrição;

- Uma reação faz com que as pontas livres dos DNAs se unam às pontas livres dos vetores, gerando um inserto;

- Os vetores são inseridos em bactérias. Ao se reproduzirem, elas copiam seus vetores de clonagem como se fizessem parte de seus próprios materiais genéticos e geram, cada uma, sua própria colônia. Tem-se então várias colônias de bactérias, onde todos os milhões de indivíduos de cada colônia têm uma cópia do mesmo vetor de clonagem; 


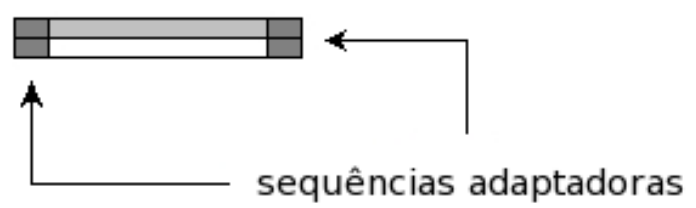

DNA com sequências adaptadoras

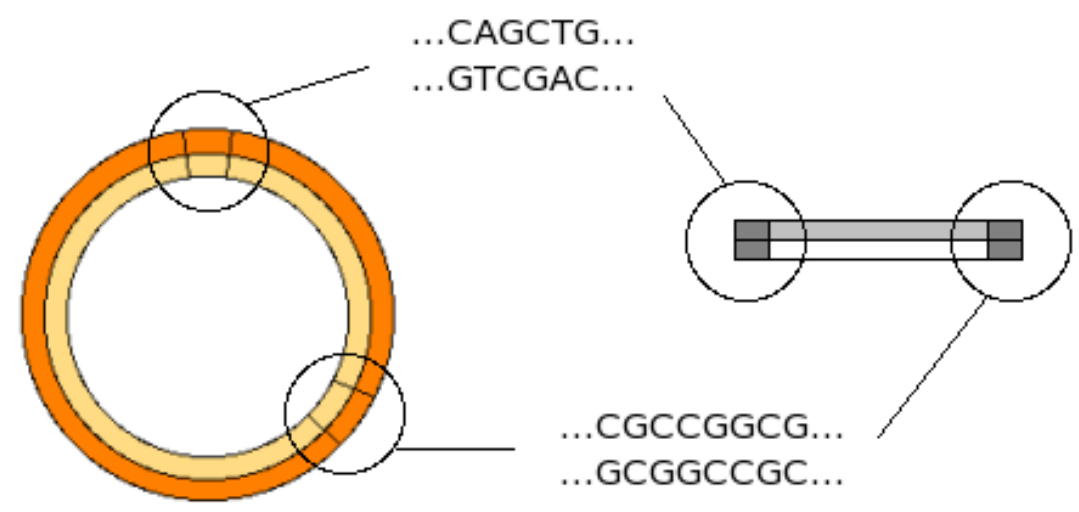

DNA e vetor de clonagem

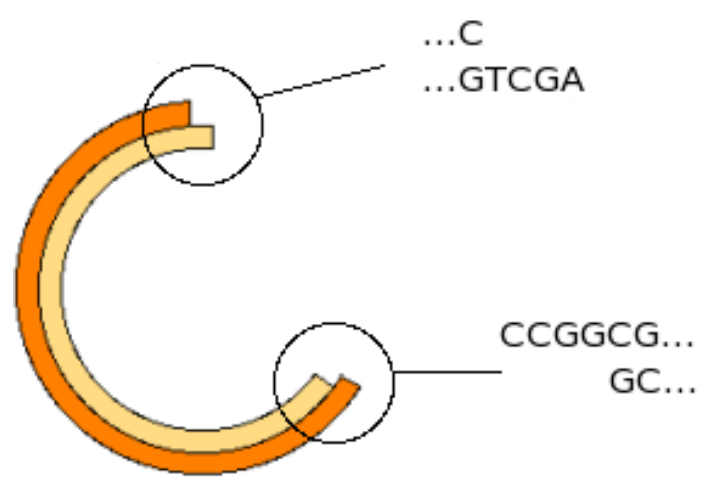

AGCTG..

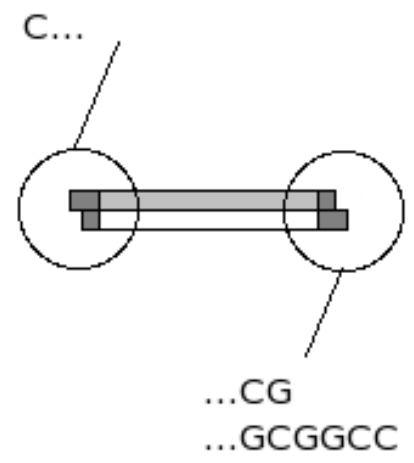

DNA e vetor de clonagem após reação com enzimas de restrição

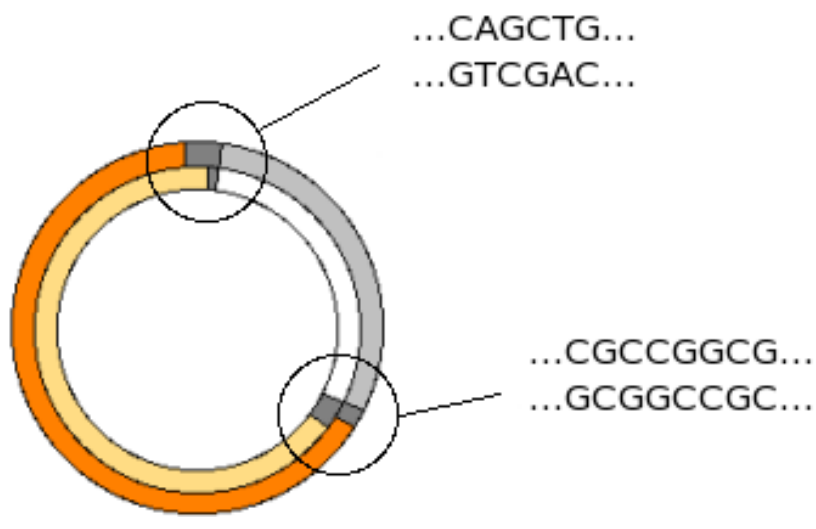

Vetor com inserto

Figura 3.5: Clonagem dos cDNAs através de bactérias. Adaptada a partir de Telles (2002). 
- As bactérias são rompidas, lavadas e filtradas para a obtenção dos vetores de clonagem;

- Cada conjunto de milhões de cópias de um inserto é preparado e seqüenciado uma única vez dando origem aos ESTs. O tamanho de cada EST varia entre 300 e 700 bases.

Para cada base seqüenciada é possível que seja associada uma medida de precisão com que ela foi lida, chamada qualidade da base ou qualidade phred (Ewing et al., 1998). Phred é um programa que interpreta um eletroforograma, que é um arquivo gráfico resultante do seqüenciamento, e produz as seqüências de bases e suas qualidades. A qualidade phred $q$ de uma base é definida como:

$$
q=-10 \times \log _{10}(p)
$$

onde $p$ é a probabilidade de erro estimada para a base. Assim, uma base com probabilidade $10^{-3}$ ( $p=0,001)$ de estar errada recebe o valor de qualidade 30. Os arquivos de qualidades das bases são usados pelo montador CAP3, apresentado no Capítulo 4, para produzir agrupamentos e gerar seqüências consenso destes agrupamentos.

Os ESTs deste trabalho são advindos do projeto SUCEST (Souza, 2006). Neste projeto, que produziu aproximadamente 300.000 ESTs de cana-de-açúcar, buscava-se a formação de grupos de ESTs semelhantes para avaliar a redundância do conjunto de dados e para obter seqüências mais longas através de sobreposições entre elas.

\subsection{Considerações finais}

Este capítulo introduziu conceitos sobre a biologia molecular para a compreensão de estruturas e de processos intracelulares. Com estes conceitos bem definidos, pudemos mostrar do que se tratam os ESTs e como eles são produzidos em laboratório. Os ESTs são os dados brutos na realização deste trabalho e precisam ser adequados a uma forma que possam ser visualizados para contribuir na descoberta de conhecimento por parte dos biólogos.

O estudo sobre biologia molecular é necessário para ressaltar a importância dos genes contidos em um DNA. Além de carregarem a herança genética entre gerações de uma espécie, eles ainda originam as proteínas, que têm diversas funções dentro da célula. Ao estudarmos os ESTs, estamos também estudando aqueles que o originaram, os genes, e os produtos dos genes, as proteínas. As técnicas para a produção dos ESTs são relativamente simples, entretanto, podem produzir dados que carreguem algumas dificuldades para serem trabalhados, desde o não mapeamento direto entre ESTs e genes até a possível contaminação de sequiências no laboratório. Várias ferramentas de bioinformática têm sido desenvolvidas a fim de atenuar estas dificuldades e permitir um melhor aproveitamento dos ESTs no estudo da genética.

O próximo capítulo aborda a metodologia adotada para trabalhar com os ESTs obtidos. Primeiramente, é mostrado como os dados são processados por ferramentas de bioinformática para a adequação aos moldes de dados a serem visualizados e, em seguida, como são visualizados. 


$\frac{7}{4}$

\section{Metodologia para a transformação dos} dados

Nos capítulos anteriores foram descritas as áreas de pesquisa deste trabalho, assim como foram introduzidos conceitos importantes a respeito da biologia molecular a fim de mostrar a técnica de obtenção dos ESTs. De posse destes dados, foi preciso que eles fossem transformados por ferramentas de bioinformática para produzir uma representação visual para apoio à exploração dos dados. Este capítulo aborda os passos necessários para a produção dos vértices e das arestas de um grafo representante dos dados, além de organizá-los em arquivos e preparar a base de dados. A manipulação de dados demonstrada neste capítulo utiliza, como exemplo, amostras dos dados do projeto SUCEST.

A Seção 4.1 traz uma visão geral da metodologia, descrevendo brevemente os passos percorridos até a visualização do grafo. A Seção 4.2 mostra o passo de montagem de seqüências através do programa CAP3 em grupos de seqüências a fim de mapeá-los como vértices. A Seção 4.3 mostra o passo de alinhamento entre os grupos de sequiências através do algoritmo BLAST para que arestas possam ser incorporadas ao grafo. A Seção 4.4 mostra como construir o arquivo do grafo de entrada a partir das informações geradas nos passos anteriores. Além disso, é descrita a preparação da base de dados, que possibilita consultas dinâmicas sobre as seqüências. A Seção 4.5 mostra como é feita a visualização do grafo, apontando as características da ferramenta TG WikiBrowser V1.02 (TGWB), escolhida como base para a implementação da ferramenta apresentada neste trabalho (ver Capítulo 5). 


\subsection{Visão geral}

Com o conceito de EST definido, é possível desenvolver uma forma de visualizar os ESTs de modo a ajudar biólogos na exploração e na descoberta de conhecimento sobre estas seqüências. Estabelecemos uma seqüência bem definida de passos para o tratamento dos dados genéticos, estabelecemos uma seqüência de passos bem definida. Para realizar estes passos, utilizam-se algumas ferramentas já existentes, outras com nossas modificações e programas implementados de acordo com as necessidades da aplicação. Na Figura 4.1 pode-se observar os passos necessários até a visualização de um grafo, onde um vértice representa um agrupamento de ESTs (contig) ou um agrupamento unitário de EST (singlet), que trataremos por contig unitário. Um agrupamento unitário é produzido quando um EST não se encaixa em nenhum grupo. As arestas do grafo são obtidas pela similaridade entre os contigs produzidos.

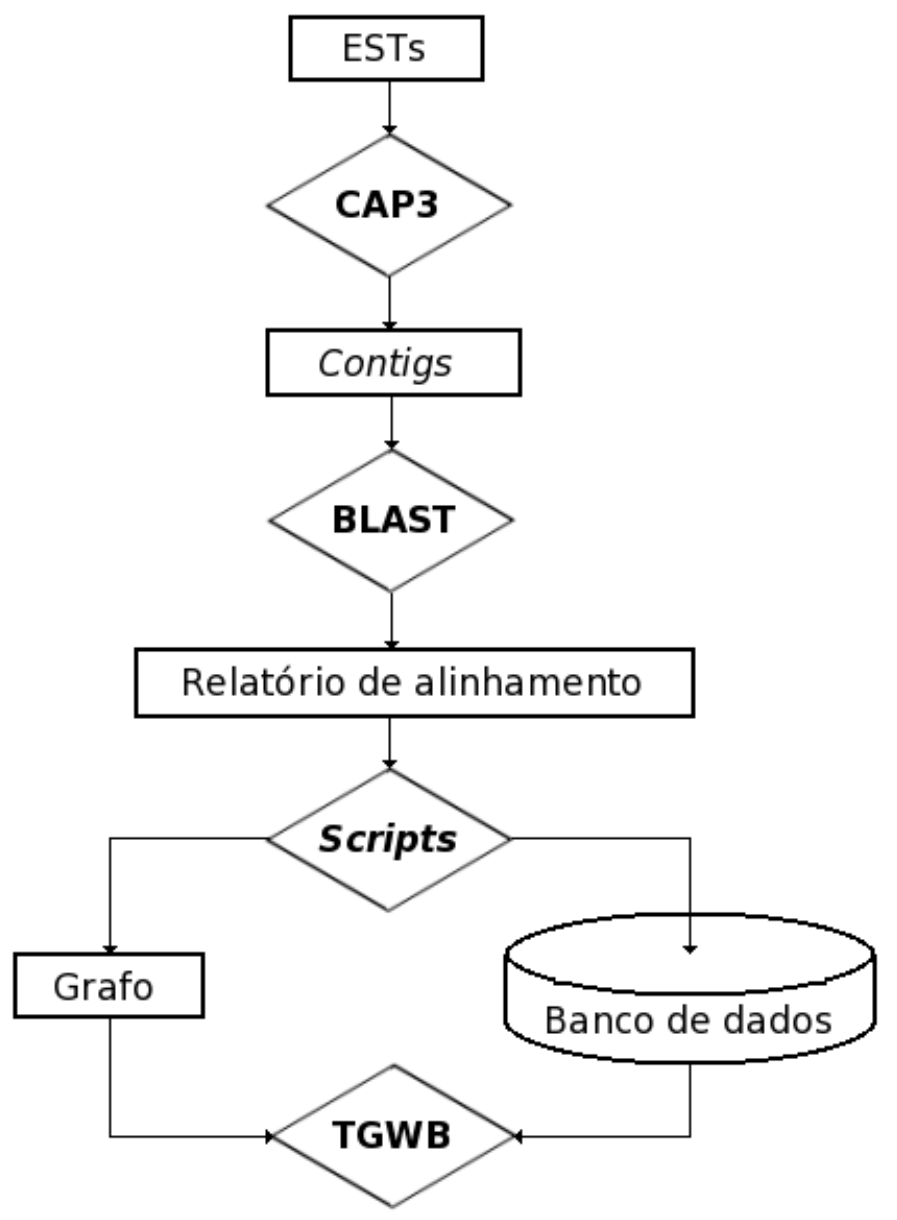

Figura 4.1: Metodologia adotada até a visualização do grafo.

Os passos apresentados na Figura 4.1 envolvem diferentes algoritmos e arquivos que precisam ser conectados até atingir a etapa final, a visualização. Primeiramente, os ESTs originais são submetidos ao programa CAP3 (ver Seção 4.2), que é um montador de seqüências, ou seja, agrupa as seqüências mais parecidas em grupos chamados contigs e, para elas, monta uma seqüência que 
as represente. Esta sequiência representante recebe o nome de consenso. Como saída, o programa CAP3 gera arquivos contendo os consensos, os contigs unitários e um arquivo que informa a qual consenso pertence um EST. Desta forma, os vértices que serão visualizados já estão definidos: ou eles são representantes de um conjunto de seqüências ou são seqüências que não forma atribuídas a nenhum grupo.

O próximo passo é a atribuição de arestas a estes vértices. A maneira encontrada para isso foi utilizar a saída do programa CAP3 como entrada para o algoritmo BLAST, que faz o alinhamento local de seqüências. O BLAST toma as seqüências de consensos e as seqüências de contigs unitários duas a duas e tenta alinhá-las, buscando alinhamentos que possuam pontuações acima de um limiar preestabelecido. Ao final do algoritmo, é emitido um relatório contendo as sequiências que obtiveram alinhamentos, os locais dos alinhamentos e a pontuação atingida, entre outras informações. Na formação do grafo, as seqüências com os alinhamentos mais significativos recebem uma aresta interligando os vértices representantes destas sequiências. Para gerar os arquivos que contenham os vértices e as arestas é necessário que o relatório gerado pelo BLAST passe por um parser escrito em Perl (desenvolvido pelo prof. Guilherme P. Telles). Este parser pode identificar as seqüências alinhadas e assim construir um arquivo contendo os vértices, de forma que a maneira com que os vértices são escritos no arquivo indica a existência das arestas. Adicionalmente, uma base de dados é construída para possibilitar consultas durante a visualização. Para isso, utilizou-se o banco de dados PostgreSQL ${ }^{1}$. Finalmente, após a construção do arquivo do grafo e da base de dados, aplica-se o programa TG WikiBrowser (TGWB), já adaptado durante este trabalho para a visualização das seqüências.

As próximas seções apresentam com mais detalhes os passos da metodologia descrita nesta seção. Algumas destas etapas tiveram seus algoritmos originais modificados para que os resultados fossem adequados aos propósitos deste trabalho. Estas modificações também são descritas nas seções que se seguem.

\subsection{CAP3}

Depois do processo descrito no Capítulo 3, um arquivo de ESTs é gerado. O arquivo segue o formato FASTA (NCBI, 2006), onde uma linha representa o rótulo de uma sequiência (sempre começando pelo símbolo '>’) e as linhas subseqüentes descrevem as bases desta seqüência propriamente dita, até que esta seqüência termine e outra comece (ver Figura 4.2).

O CAP3 (Contig Assembly Program 3) é um programa do tipo montador. Ele recebe um conjunto de seqüências de DNA como entrada e, em função de sobreposições entre elas, produz contigs e, para cada contig, produz uma seqüência consenso, que é uma super-sequiência de todas as que fazem parte do contig (Huang e Madan, 1999). Normalmente, os programas de montagem permitem definir parâmetros para o seu funcionamento, como o número mínimo aceitável de bases

\footnotetext{
${ }^{1}$ Banco de dados Disponível em http: / / www . postgresql . org/.
} 


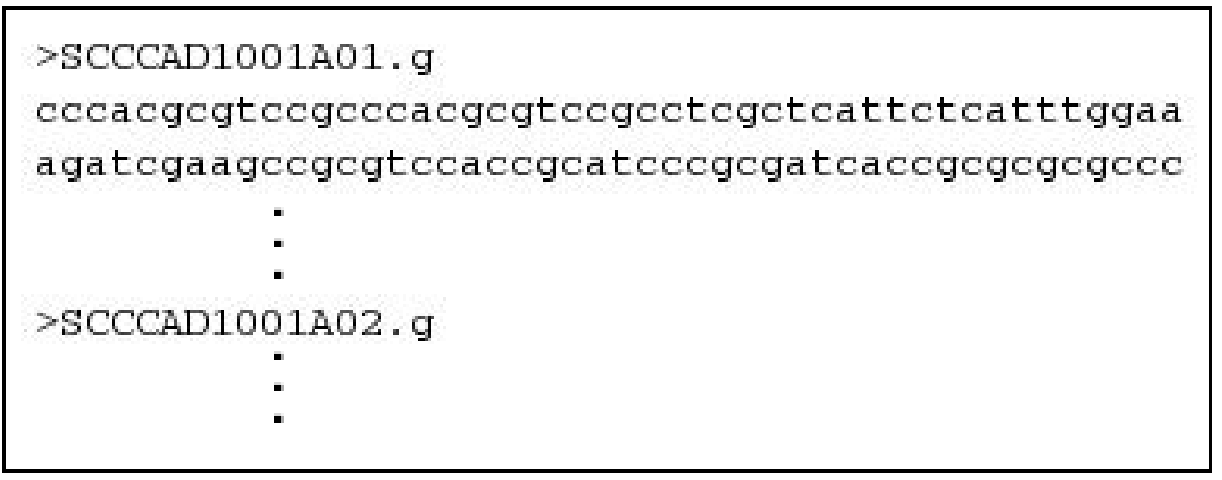

Figura 4.2: Formato FASTA do arquivo de ESTs.

em uma sobreposição de duas seqüências e a quantidade máxima de bases divergentes em uma sobreposição. Neste trabalho, o CAP3 recebe somente ESTs como entrada.

O programa possui três passos, conforme ilustra a Figura 4.3. Primeiramente, as regiões de baixa qualidade 3' e 5' (ver Capítulo 3) de cada sequiência são identificadas e removidas. Além disso, as sobreposições são computadas e falsas sobreposições entre sequiências também são identificadas e removidas. Na segunda fase, as seqüências são agrupadas para formar contigs em ordem decrescente de pontuação das sobreposições. Por último, alinhamentos múltiplos de sequiências são construídos e um valor de qualidade para cada base de um contig é computado. Estes valores são usados na construção dos consensos (Huang e Madan, 1999).

As pontuações para sobreposições corretas (matches), sobreposições incorretas (mismatches) e penalidade para buracos dependem da qualidade das bases envolvidas. Isso quer dizer que um match entre bases com qualidade alta resulta em uma pontuação positiva grande e um mismatch entre bases com qualidade alta resulta em uma pontuação negativa grande. Analogamente, matches e mismatches entre bases de baixa qualidade resultam em valores positivos e negativos pequenos, respectivamente. Os valores de qualidade das bases são levados em consideração durante a construção das seqüências consenso. Para cada coluna de um alinhamento múltiplo de seqüências, uma soma dos valores de qualidade é calculada para cada tipo de base existente e o tipo de base que possuir a maior soma é colocada como a base consenso para a coluna.

A montagem de amostras de dados obtidos do projeto SUCEST pelo CAP3 permitiu produzir diversos exemplos de grafos. Em um destes exemplos, que chamaremos de EXEMPLO_SUCEST, contamos com uma amostra de 5.000 ESTs obtidos aleatoriamente de um conjunto que continha aproximadamente 300.000 ESTs de cana-de-açúcar, emitindo como resultado um arquivo de contigs, com pouco mais de 400 consensos, e um arquivo de singlets, com mais de 3.500 contigs unitários. Estes arquivos seguem o formato FASTA e as sequiências - cerca de 4.000 entre consensos e contigs unitários - são tratadas como os vértices do grafo a ser construído, ou seja, cada seqüência, seja ela um consenso ou um contig unitário, possui um vértice que a representa no grafo. Além destes arquivos, foi gerado também um arquivo de relacionamento entre ESTs e contigs. Este arquivo possui, além de outras informações, os rótulos dos contigs e os rótulos dos 


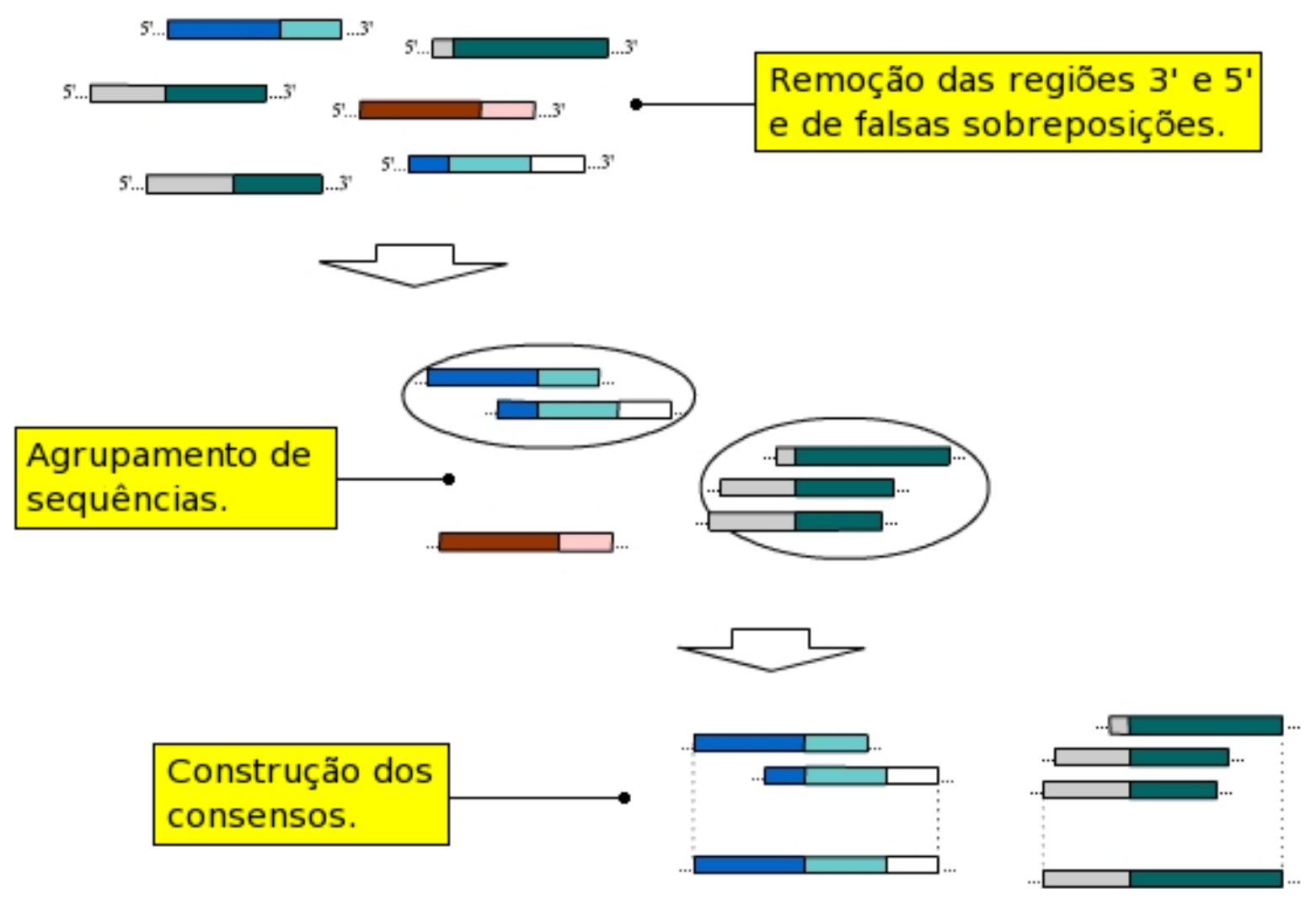

Figura 4.3: Funcionamento do montador CAP3.

ESTs que fazem parte de cada contig. No próximo passo, com a utilização do algoritmo BLAST, é mostrado como foram criadas as arestas para os vértices deste exemplo.

\subsection{BLAST}

O BLAST (Basic Local Alignment Search Tool) é um dos algoritmos mais utilizados para alinhamento local de sequiências de proteínas e DNAs. Um alinhamento local entre duas sequiências é formado por trechos sobrepostos destas seqüências que, após receberem a inserção de zero ou mais buracos em posições arbitrárias, possuem o mesmo tamanho e com bastante similaridade. Isto faz com que não seja necessário um alinhamento de toda a sequiência para que o mesmo seja reportado. O algoritmo é baseado em uma pontuação chamada HSP (high-scoring segment pair) e, segundo Altschul et al. (1997), é bem mais veloz do que outros algoritmos ótimos que utilizam programação dinâmica, caros por possuírem complexidade $O(r \cdot s)$ para cada duas sequiências de tamanhos $r$ e $s$ alinhadas.

Na busca por alinhamentos dentro de uma base de dados de milhares de sequiências, geralmente apenas algumas terão trechos similares à seqüência pesquisada (query). Portanto, é interessante identificar somente as seqüências que formam um HSP com a query. Um HSP é conseguido quando a pontuação de um alinhamento entre duas seqüências, acima de um limiar $S$, não pode 
ser aumentada estendendo ou encurtando este alinhamento. A procura por um HSP só acontece quando uma palavra da query é alinhada com um trecho de outra sequiência atingindo uma pontuação de pelo menos $T$. Este alinhamento entre uma palavra e um trecho de outra seqüência recebe o nome de hit. Uma palavra $w$ é um pequeno trecho da sequiência query (em geral, $w=12$, para seqüências de DNA). Assim, uma seqüência de tamanho $n$ e uma palavra de tamanho $m$ produzem $n-m+1$ palavras. Apenas aquelas sequiências que conseguem os hits têm seus alinhamentos estendidos, poupando custo computacional com as seqüências que não conseguem hits. $\mathrm{O}$ alinhamento com inserção de buracos permite ainda que o algoritmo reporte um alinhamento maior ao invés de vários entre duas seqüências, uma vez que, com a presença de buracos, pode-se estender o alinhamento. $\mathrm{O}$ algoritmo pode ser descrito nos três seguintes passos (ver Figura 4.4):

1. Lista todas as palavras de uma sequiência query;

2. Procura alinhamentos entre as palavras listadas e os trechos de outras sequiências com pontuação de pelo menos $T$. Tais alinhamentos são chamados hits;

3. Estende o alinhamento para ambos os lados dos hits encontrados, reportando apenas aqueles que superam a pontuação mínima $S$.

O algoritmo BLAST disponibiliza filtros automáticos para substituir trechos de sequiências de baixa complexidade. Estes trechos são facilmente identificados em inspeções visuais tamanha sua simplicidade (por exemplo, 'AAATAAAAAAAATAAAAAAT'). Eles podem causar hits não verdadeiros, desbalanceando a pontuação. Os filtros agem substituindo estes trechos por cadeias da letra ' $N$ '.

Para cada alinhamento encontrado, o algoritmo BLAST fornece também o seu valor esperado ou a medida de confiança da pontuação $S$ (e-value). O e-value descreve o número de hits que uma pessoa pode esperar conseguir ao acaso quando estiver realizando uma busca em uma base de dados. Por exemplo, um e-value $E$ tal que $E=0.001$ em uma base de dados com 1 milhão de entradas ainda deixaria 1.000 entradas sem confiança. Já um $E=e^{-6}$ na mesma base deixaria apenas uma entrada sem confiança, ou seja, o alinhamento é provavelmente único e não devido a um erro. $\mathrm{O}$ valor do $e$-value se aproxima exponencialmente de 0 com o aumento da pontuação $S$. Essencialmente, o e-value descreve o ruído aleatório que existe para matches entre seqüências. Isto significa que quanto mais próximo de 0 o e-value esteja, mais "significante" é o match. Como os alinhamentos são representados pelas arestas do grafo e os e-values seus valores de significância, estes valores são atribuídos como pesos das arestas com o propósito de possibilitar a filtragem dos dados (ver Capítulo 5).

Ao longo do tempo, algumas melhorias foram incorporadas ao algoritmo original (Altschul et al., 1990) visando poupar processamento e diminuir o percentual de perda de alinhamentos. Entre elas, Altschul et al. (1997) sugerem o alinhamento a partir de um hit duplo. Este refinamento baseia-se no fato de que um alinhamento de interesse é muito maior que um simples par de palavras 
(a)

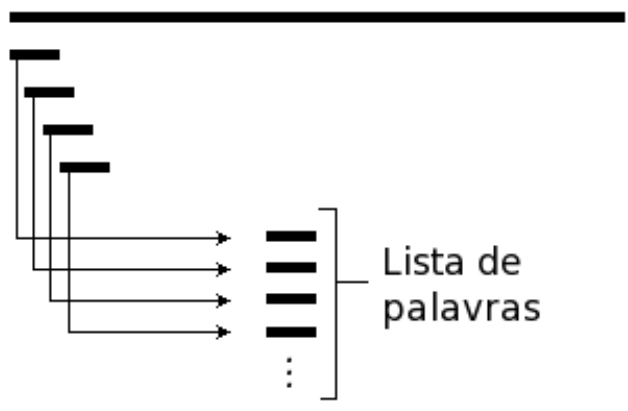

(b)

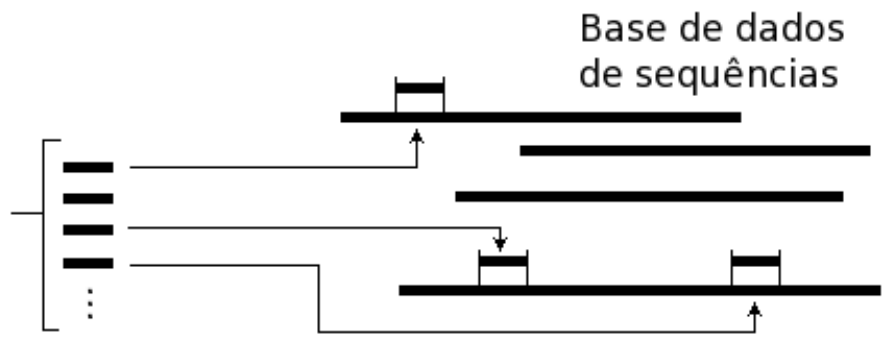

(c)

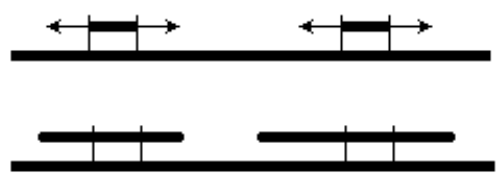

Extensão de alinhamentos

Figura 4.4: Funcionamento do algoritmo BLAST para seqüências de DNA ou proteínas. (a) Mostra a lista de palavras da query. (b) Procura por hits em uma base de seqüências. (c) Estende o alinhamento para os hits.

alinhadas. Logo, é provável que ocorra mais de um hit na mesma diagonal (ver Figura 4.5). Assim, só serão estendidos os alinhamentos que possuírem duas palavras alinhadas, não sobrepostas e com uma distância entre elas menor que um valor $A$ (em geral, $A=40$ posições entre o começo das palavras).

Os arquivos de contigs e de contigs unitários do EXEMPLO_SUCEST obtidos através do processamento do CAP3 serviram de entrada para o algoritmo BLAST encontrar alinhamentos entre as seqüências dos dois arquivos. Quando os alinhamentos encontrados são significativos eles são representados por arestas na visualização do grafo. O BLAST reporta os alinhamentos entre as próprias seqüências do arquivo Contigs (contigs $\mathrm{x}$ contigs), entre as sequiências do arquivo Contigs e as sequiências do arquivo Singlets (contigs x contigs unitários) e entre as próprias sequiências do arquivo Singlets (contigs unitários x contigs unitários). A saída emitida pelo BLAST é em forma de relatório, contendo dados como: o rótulo das sequiências alinhadas, a pontuação obtida, a porcentagem de acerto, o $e$-value, o trecho alinhado e outras informações (ver Figura 4.6). A próxima seção mostra como o arquivo do grafo do exemplo é construído, ao mesmo tempo em que é criada sua base de dados. 


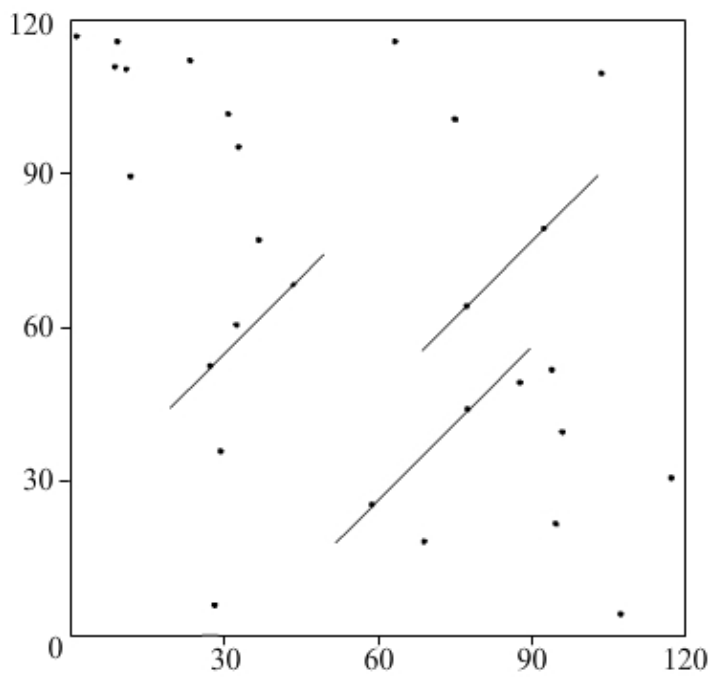

Figura 4.5: Exemplo de hits duplos. Os eixos dos gráficos representam as bases de duas sequiências hipotéticas. Na figura, pode-se ver todos os hits, marcados por pontos, entre as duas seqüências. Entretanto, os únicos alinhamentos a serem estendidos possuem dois hits na mesma diagonal.

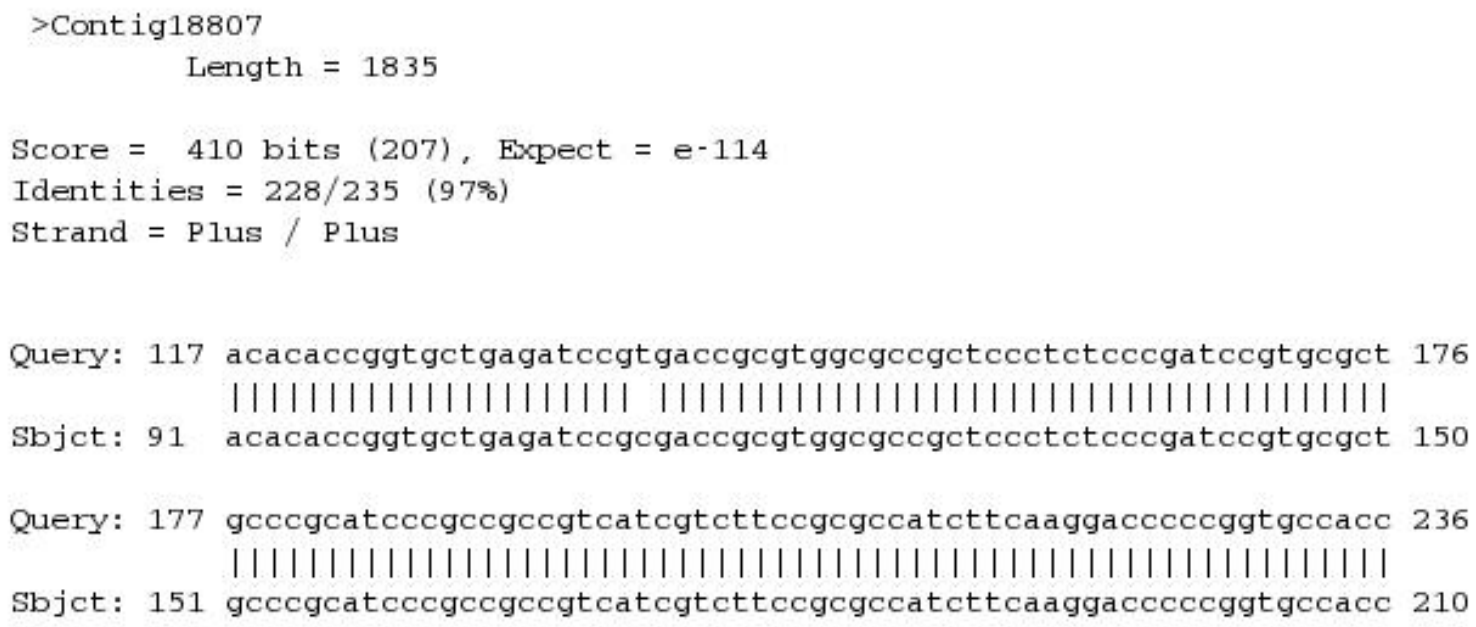

Figura 4.6: Relatório de alinhamento gerado pelo BLAST. Acima na figura é mostrado o rótulo da seqüência com a qual a query fez alinhamento. No centro, diversas informações, entre elas a pontuação e o $e$-value. Mais abaixo é mostrado onde começa e termina o alinhamento entre as sequiências query e subject com as bases alinhadas por barras verticais.

\subsection{Construção do grafo e preparação da base de dados}

Depois da utilização do algoritmo BLAST, é gerado um relatório indicando os alinhamentos obtidos. No caso do EXEMPLO_SUCEST são gerados três relatórios. Cada relatório segue o esquema apresentado na Figura 4.6. O próximo passo foi aplicar o parser escrito em Perl nestes arquivos para descobrir onde havia arestas conectando os vértices. Todos os resultados foram 
unidos em um único arquivo, evitando as redundâncias. Ao mesmo tempo, foi construído um arquivo seguindo o mesmo formato do arquivo do grafo somente para armazenar os $e$-values das arestas. Além disso, foi criada uma base de dados contendo alguns dados úteis a respeito das seqüências para permitir consultas durante a visualização.

O parser para os relatórios do BLAST foi escrito em Perl principalmente para aproveitar as facilidades oferecidas pela linguagem no que diz respeito à manipulação de cadeias de caracteres e expressões regulares. Seu objetivo é varrer os arquivos extraídos do BLAST, classificando e armazenando os tokens encontrados em uma estrutura. Com estas informações pode-se construir o arquivo do grafo. A idéia é percorrer a estrutura e a cada célula escrever o nome da seqüência no arquivo de grafo. Depois disso, basta investigar os subníveis da estrutura para escrever no arquivo os nomes das seqüências que têm alinhamento com a primeira. Ao final de uma célula, insere-se uma quebra de linha no arquivo, indicando que outro vértice será escrito. Desta forma, o arquivo fica similar a uma lista de adjacências dirigida, onde as arestas apontam de uma seqüência query para uma seqüência subject.

Após a utilização do parser para transformar os relatórios de alinhamentos em arquivos de grafos de entrada para a ferramenta de visualização, foi necessário unir estes arquivos em apenas um. Esta tarefa é simples, mas deve ser feita com cuidado para evitar redundâncias, como criar um mesmo vértice mais de uma vez. Os arquivos de grafos estão na forma de listas de adjacências, ou seja, o primeiro rótulo de cada nova linha é um vértice a ser criado, enquanto que todos os outros rótulos subseqüentes a este são vértices que possuem arestas ligando-os ao primeiro vértice. Como podemos ter um mesmo rótulo em dois arquivos distintos devemos checar linha-a-linha dos arquivos para anexar um ao outro sem repetições de vértices, verificando se o primeiro rótulo de uma linha lida de um arquivo A é igual ao primeiro rótulo de uma linha lida de um arquivo B. Caso sejam iguais, copiamos todos os símbolos subseqüientes ao rótulo do arquivo $\mathbf{B}$ e escrevemos esta cópia no final da linha do rótulo do arquivo A (ver Figura 4.7).

A montagem do arquivo de e-values seguiu a mesma forma apresentada na montagem dos arquivos de grafos. Entretanto, não há marcações para identificar a qual aresta um $e$-value pertence. Por isso, é necessário que a montagem deste arquivo seja simultânea ao do grafo para que os $e$ values sejam atribuídos às arestas corretamente.

Para possibilitar consultas sobre os vértices do grafo e, conseqüentemente, sobre os contigs, é necessária a construção de um banco de dados contendo informações sobre os ESTs originais e os consensos obtidos do CAP3. Como pode ser visto pelo diagrama apresentado na Figura 4.8, o banco de dados é simples, contendo apenas três tabelas: Seqüências originais, Contigs e Novos relacionamentos. A tabela Seqüências originais é a maior tabela, pois contém os nomes e as sequiências de todos os ESTs originais. Ela também relaciona os ESTs com os contigs pelo campo 'número do contig' aproveitando o arquivo gerado pelo CAP3 que disponibiliza estas informações. Se este valor for nulo significa que o EST não pertence a nenhum grupo e portanto é um contig unitário. O campo de qualidade da seqüência é utilizado em uma possível remontagem de vértices (ver Capítulo 5). A tabela Contigs contém os números dos contigs e as seqüências de seus 
contigs $\mathrm{x}$ singlets

\begin{tabular}{|l}
\hline singlet1 contigi ... \\
$\vdots$ \\
singlet2 ..... \\
$\vdots$ \\
$\vdots$ \\
singletm .....
\end{tabular}

\section{singlets $\mathrm{x}$ singlets}

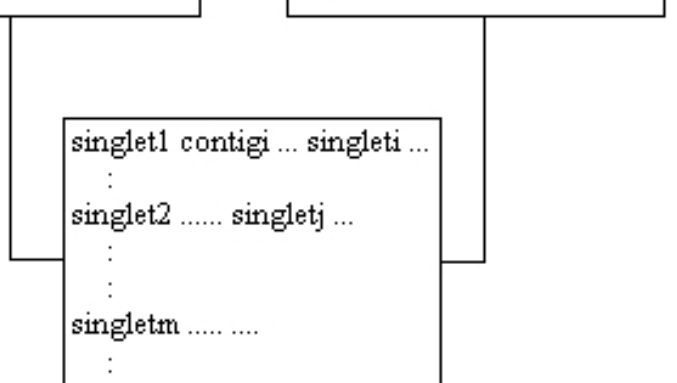

contigs $\mathrm{x}$ contigs

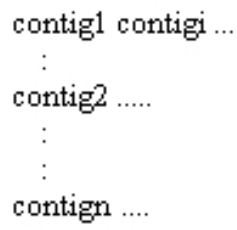

\section{grafo completo}

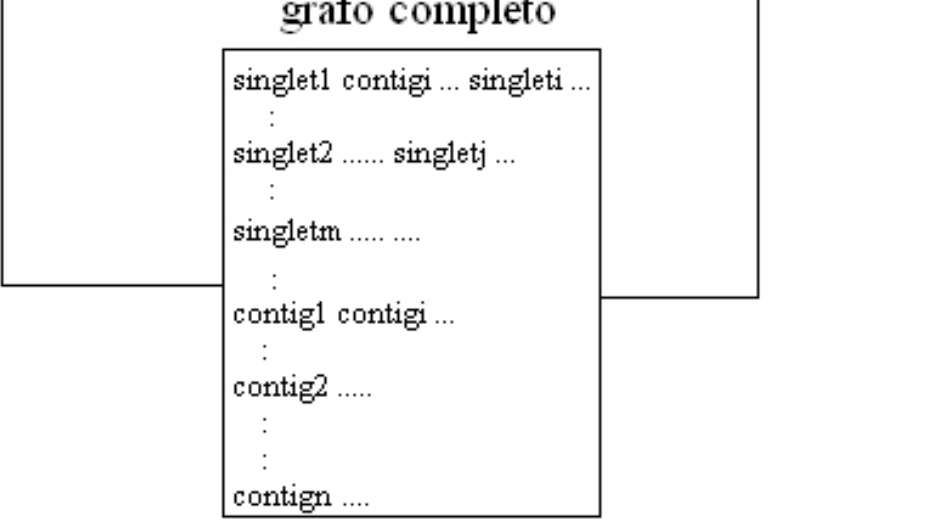

Figura 4.7: União dos arquivos em um único arquivo de grafo. Os nomes separados pelo símbolo ' $\mathrm{x}$ ' que aparecem acima dos arquivos indicam a ordem que foi realizada a busca de alinhamentos pelo BLAST. À esquerda de ' $\mathrm{x}$ ' são as seqüências subjects e à direita as queries. Esta ordem é indicada durante a visualização pelo desenho das arestas.

consensos. A tabela Novos relacionamentos é destinada a armazenar informações dos vértices remontados durante o processo interativo de visualização. Ela guarda apenas as chaves das seqüiências remontadas junto com o número do novo contig ao qual elas pertencem. O novo contig tem seu número e seqüência inseridos na tabela Contigs.

Ao final desta etapa, há dois arquivos que geram o grafo com o peso das arestas e um banco de dados das sequiências. Os arquivos são passados como parâmetros de entrada ao programa de visualização de grafos e a conexão do banco de dados com este programa é estabelecida na sua execução. A próxima seção traz uma visão geral da ferramenta utilizada para a visualização dos ESTs transformados em grafos. 


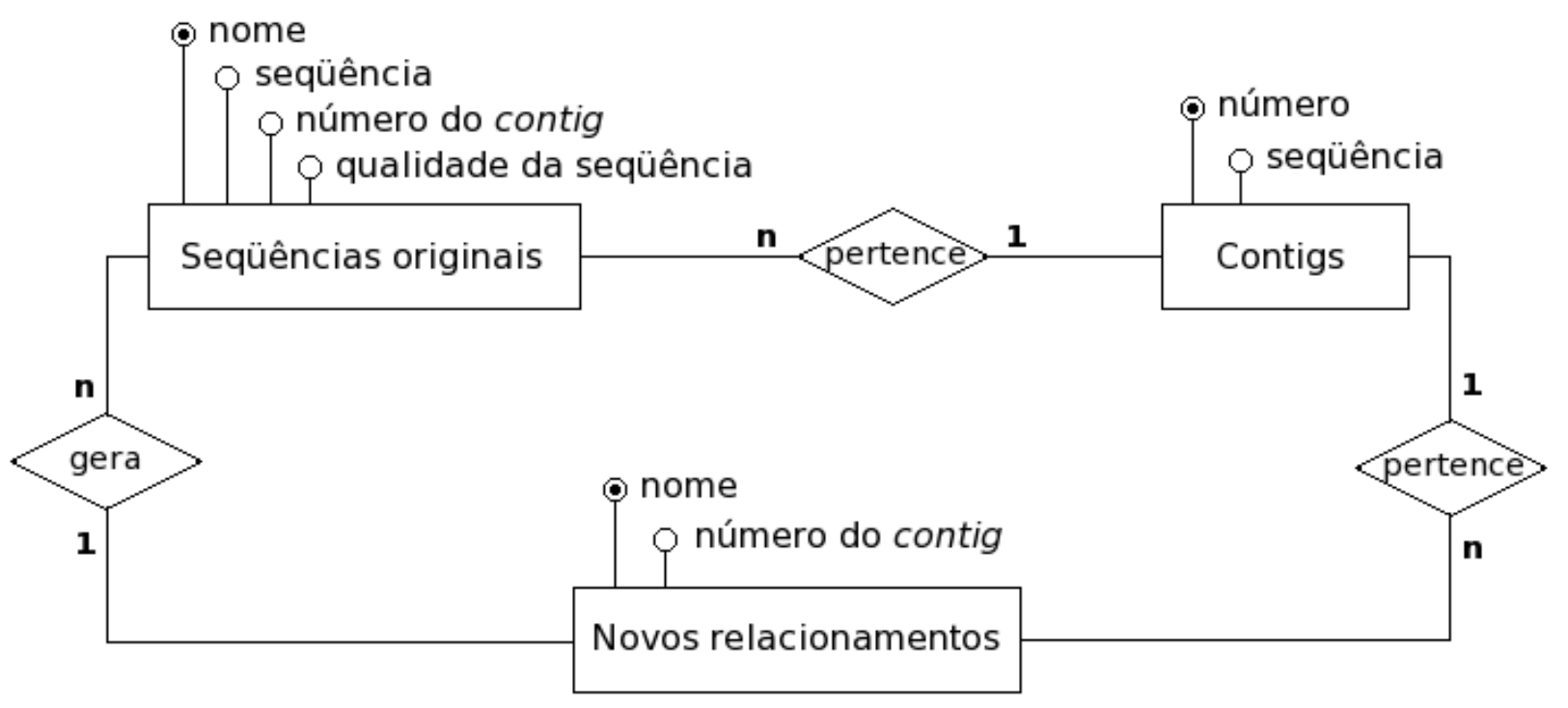

Figura 4.8: A base de dados é composta por três tabelas: a primeira armazena todas as seqüências originais, a segunda armazena somente os contigs e a terceira armazena informações de vértices remontados.

\subsection{Visualização dos ESTs}

As seções anteriores mostraram a construção dos arquivos de grafo e da base de dados. Para a visualização dessa representação, buscou-se uma ferramenta com código fonte aberto que já dispusesse algumas possibilidades de interações com uma visualização útil. A ferramenta escolhida foi a TG WikiBrowser V1.02, que é uma versão aprimorada do seu sistema original, o TouchGraph.

A navegação visual sobre uma rede é um processo inerentemente dinâmico e certos passos precisam ser seguidos para manter o usuário orientado e sentindo-se no controle. O TouchGraph consegue isso mantendo o grafo tão estático quanto possível e se certificando que as mudanças sejam previsíveis, repetitivas e possíveis de serem desfeitas (Shapiro, 2006). O TouchGraph é um programa escrito em Java que permite a visualização de redes de informações inter-relacionadas (grafos ou redes complexas). O usuário tem à sua disposição várias ferramentas de interação que agem sobre a visualização, tais como: expandir e colapsar vértices, esconder vértices e arestas, arrastar o grafo ou a imagem, filtros para controlar o número de vértices e arestas visíveis e zoomming. As interações possibilitam uma navegação simples e intuitiva sobre o grafo. Além disso, o TouchGraph utiliza um algoritmo de desenho baseado em força com a metáfora de um conjunto de molas, mostrando uma disposição equilibrada entre os vértices (ver Seção 2.2.1).

Há diversas aplicações que utilizam o TouchGraph para dar origem aos seus próprios programas de visualização de redes, tais como: o AmozonBrowser (Amazon, 2006), o GoogleBrowser (TouchGraph LLC, 2006a), o LiveJournal Browser (TouchGraph LLC, 2006b) e o próprio WikiBrowser (Shapiro, 2006). Isto mostra que o programa é bem aceito e utilizado em vários segmen- 
tos, fato que ainda contribui para o aprimoramento do código fonte. A Figura 4.9 mostra algumas ferramentas que utilizam o TouchGraph.

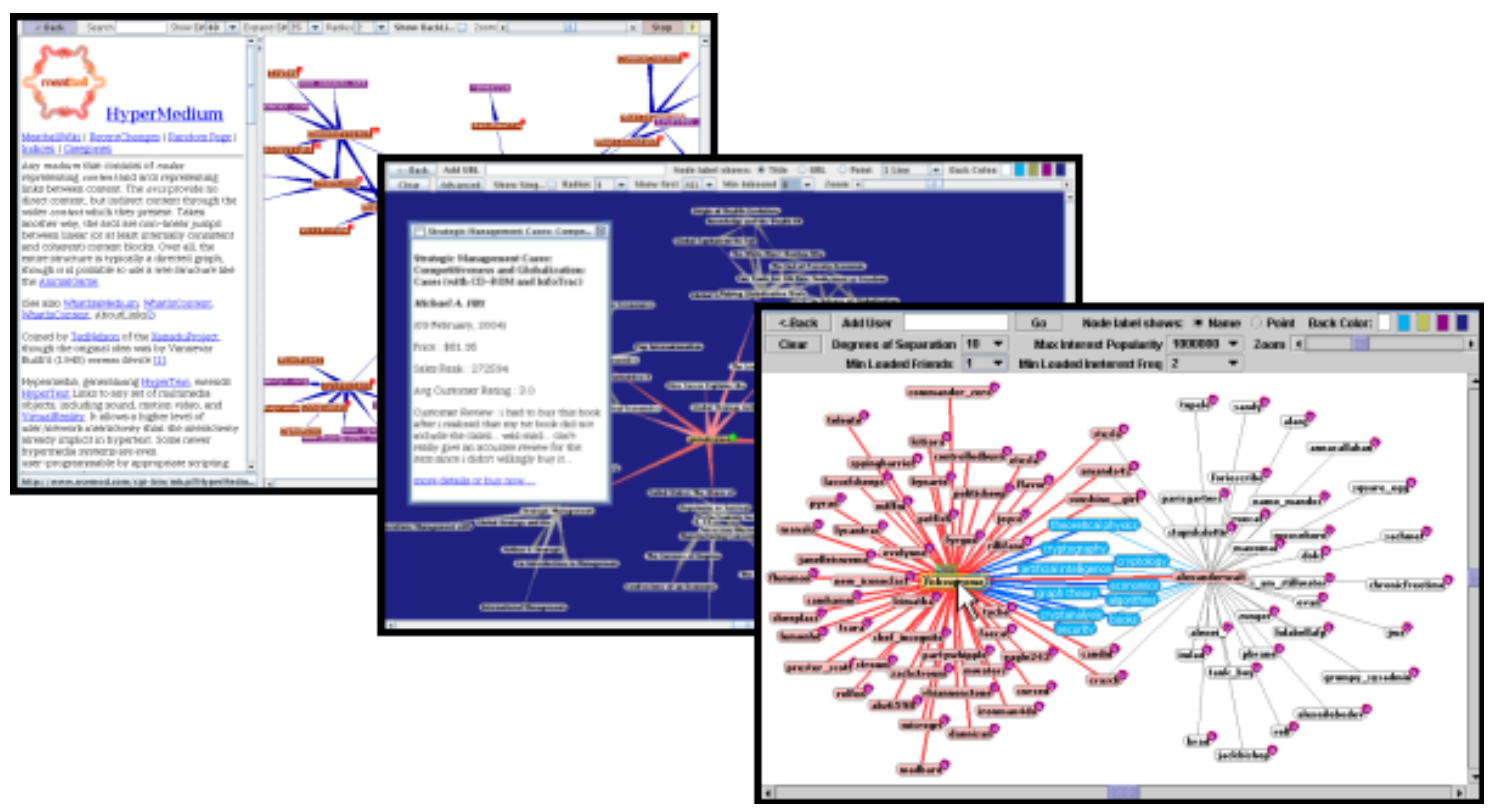

Figura 4.9: Exemplos de aplicações feitas a partir do TouchGraph.

Basicamente, o programa necessita de um arquivo de vértices como parâmetro para sua execução. A disposição destes vértices no arquivo remete a uma lista de adjacências (ver Seção 4.4). Em nossa abordagem, além do arquivo de vértices, criamos um arquivo adicional que guarda os dados dos e-values dos alinhamentos extraídos pelo algoritmo BLAST. Assim, nossa ferramenta necessita de dois arquivos de entrada, o que pode causar um tempo adicional para sua inicialização. Durante a utilização da ferramenta TG WikiBrowser, observaram-se várias melhorias e adaptações que poderiam ser feitas para que ela servisse aos propósitos deste estudo. Dentre as melhorias realizadas, pode-se destacar:

- A conexão com o banco de dados, possibilitando consultas dinâmicas sobre as seqüências;

- O novo sistema de busca, que disponibiliza uma lista de resultados para cada busca, podendo ser pelos rótulos dos vértices ou por trechos das seqüências;

- O destaque em negrito para respostas de consultas;

- A abertura de novas janelas para a inspeção minuciosa das seqüências e dos grupos de seqüências;

- A remontagem de vértices através da seleção múltipla de vértices e chamada ao programa CAP3;

- A filtragem de arestas através dos e-values; 
- A possibilidade de visualizar simultaneamente várias componentes do grafo na tela;

- O histórico da navegação nos vértices, permitindo voltar e avançar nos vértices percorridos;

- O destaque aos vértices vizinhos de um que esteja sendo inspecionado.

Houve também a necessidade de se corrigir alguns problemas encontrados no código, como algumas inconsistências e um problema que causava travamento com a versão 1.5 do Java. Estas e outras melhorias e adaptações podem ser vistas com mais detalhes no Capítulo 5, que ainda traz um estudo do desempenho da nova ferramenta. A ferramenta está disponível em http: //infoserver.lcad.icmc.usp.br/infovis2.

\subsection{Considerações finais}

Este capítulo descreveu toda a metodologia adotada por este estudo, desde o pré-processamento dos dados até a forma com que eles são visualizados. Com estes passos é possível trabalhar com os ESTs na forma de um grafo. Na questão da visualização, o programa TouchGraph teve significativa contribuição por se tratar de uma ferramenta livre, amplamente utilizada, codificada em uma linguagem portável e, a exemplo do banco de dados, com alto grau de robustez.

Neste estudo, a visualização de informação em conjunto com as ferramentas de bioinformática deram origem a uma ferramenta de exploração visual simples e de fácil aprendizado. Com o aumento do número de ferramentas disponíveis para a exploração visual de sequiências, há grandes chances de que ocorram avanços significativos tanto na visualização quanto na biologia. Esperamos que esta nova ferramenta contribua para a investigação desse tipo de dado.

O próximo capítulo mostra os resultados alcançados até o presente momento, sejam eles em termos de melhorias e novas funcionalidades e em termos de desempenho da ferramenta. Também são apontados os pontos fracos da ferramenta, como a visualização de muitos vértices simultaneamente, que pode comprometer a animação, e o tempo de inicialização, que pode ser considerado longo. 


\section{CAPÍTULO}

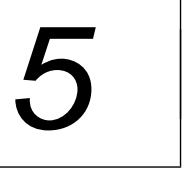

Resultados

Este capítulo descreve os principais resultados deste trabalho, tanto em termos de funcionalidades da ferramenta visual quanto em termos de desempenho da mesma. A Seção 5.1 trata das funcionalidades, abordando as tarefas interativas permitidas. A Seção 5.2 faz um breve estudo sobre o consumo de memória, o tempo de inicialização e a taxa de atualização das animações para diferentes interações. Além disso, a seção reporta alguns problemas encontrados que ainda não foram solucionados.

\subsection{Funcionalidades}

A ferramenta desenvolvida herdou diversas funcionalidades da ferramenta TG WikiBrowser. A disposição das funcionalidades segue a mesma linha e, portanto, pode ser dividida em três partes: (1) barra de funcionalidades, (2) janela de busca e (3) janela de apresentação do grafo. A Figura 5.1 ilustra estas partes. A barra de funcionalidades fica disposta na parte de cima da imagem, contendo operações como a volta e o avanço de vértices, busca, filtro para não mostrar ou não expandir vértices contendo um número de arestas acima do permitido, filtro de profundidade (número de arestas visíveis a partir do vértice selecionado), filtro pelo valor implícito $e$-value das arestas, zooming, congelamento da imagem e ajuda. À esquerda, fica posicionada a janela que retorna valores de consultas ativadas pelo campo de busca contido na barra de funcionalidades. As consultas podem ocorrer tanto no banco de dados quanto nos objetos do próprio programa, entretanto, isso fica invisível ao usuário. Os valores retornados de uma consulta para esta janela são sempre em forma de rótulos das seqüências. A terceira parte da ferramenta se refere à apresentação do grafo. A maior janela fica responsável por isso, permitindo liberdade quase que total ao usuário, 
como clicar uma ou duas vezes sobre os vértices, clicar e arrastar a imagem ou o grafo e clicar com o botão direito sobre vértices, arestas ou o plano de fundo para abrir um menu diferente para cada um destes objetos. Além disso, esta janela sofre os efeitos das ações realizadas nas outras partes da ferramenta. Nas próximas seções serão discutidos os detalhes de cada uma das três partes da ferramenta.

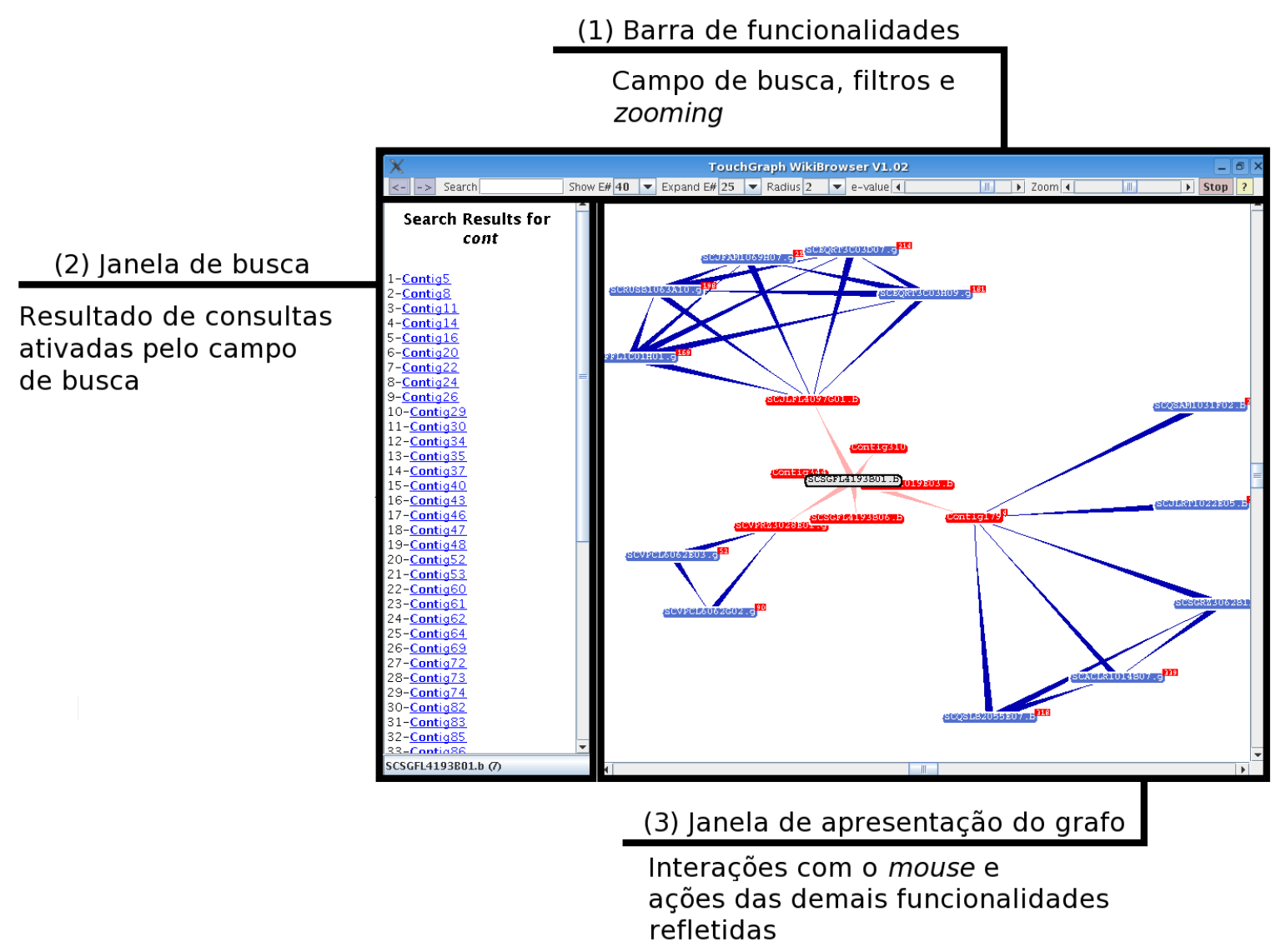

Figura 5.1: As três partes da ferramenta: (1) barra de funcionalidades, (2) janela de busca e (3) janela de apresentação do grafo.

\subsubsection{Barra de funcionalidades}

A barra de funcionalidades disponibiliza uma série de ferramentas de interação. Sua manipulação reflete na mudança de estado das janelas de busca e de apresentação do grafo. As filtragens de objetos na janela principal por número máximo de arestas permitidas e por raio do vértice selecionado são herdadas da ferramenta TG WikiBrowser (ver Capítulo 4), assim como as opções de zooming e congelamento da imagem.

Nesta parte da ferramenta, as novas funcionalidades implementadas são: volta e avanço de vértices, busca e filtragem pelos e-values das arestas. Os botões de voltar e avançar, representados por setas, funcionam de forma semelhante àqueles da maioria dos navegadores utilizados no acesso à Internet, mas aqui servem para guardar o histórico da navegação nos vértices do grafo. No campo 
de busca, o usuário pode estar à procura de rótulos de vértices ou do conteúdo dos vértices, ou seja, rótulos ou trechos de sequiências, respectivamente. Caso o usuário procure por rótulos, os resultados mostrados automaticamente na janela de busca já são a resposta da consulta. Caso ele procure por trechos de sequiências, os resultados mostrados na janela de busca indicam que estes vértices contêm o trecho procurado e, portanto, o usuário deve inspecionar a janela de detalhes dos vértices para obter o resultado desejado (ver Seção 5.1.3). A filtragem pelos e-values das arestas é realizada por uma barra de rolagem. À medida que o usuário move esta barra para a esquerda, ele diminui o valor do maior $e$-value permitido para as arestas continuarem visíveis. Se uma aresta tiver um e-value maior do que o estabelecido pelo usuário ela será escondida imediatamente (ver Figura 5.2). Sempre que um vértice é expandido, o valor do filtro é recalculado, verificando todas as arestas visíveis e atualizando a barra de rolagem com o maior $e$-value dentre aqueles das arestas presentes na tela.

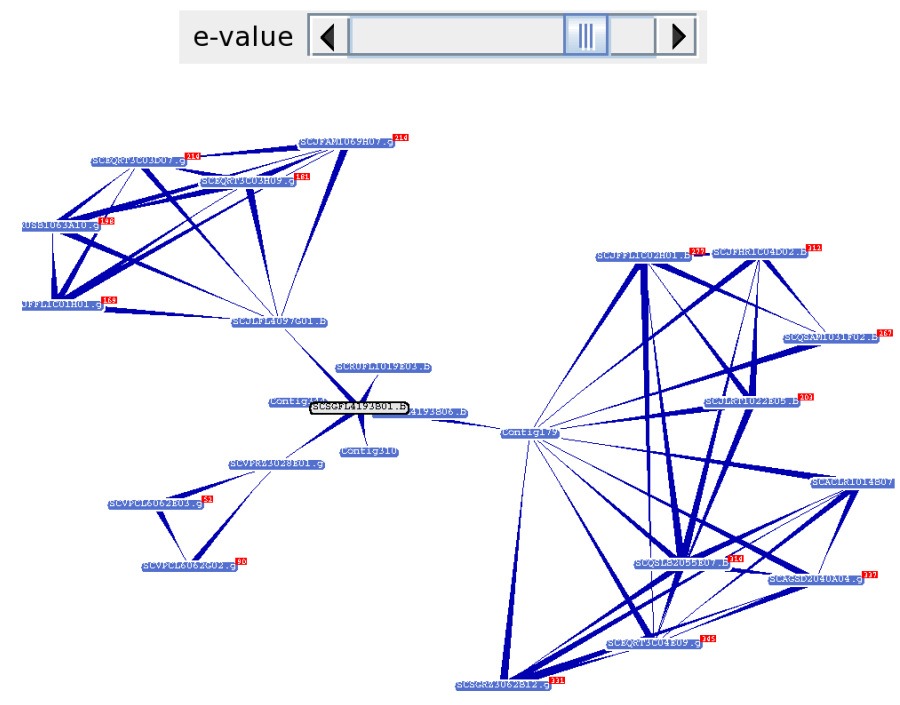

(a)
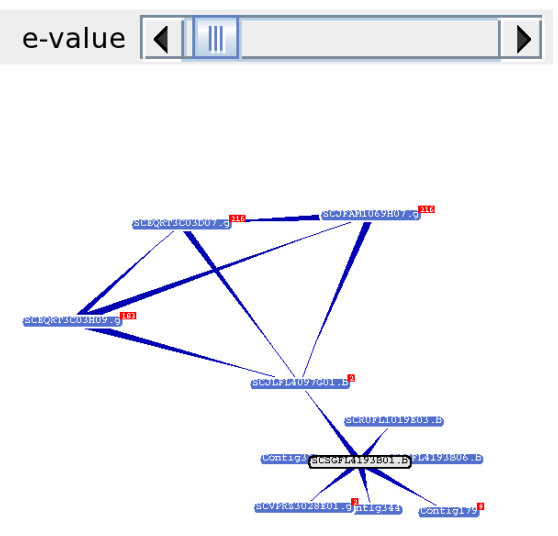

(b)

Figura 5.2: (a) Filtro de $e$-value antes de ter seu valor reduzido e grafo correspondente. (b) Filtro com valor mais próximo de zero e grafo resultante.

$\mathrm{O} e$-value de cada aresta é carregado na inicializaçao do programa juntamente com o arquivo do grafo. Por se tratarem de valores muito baixos (na ordem de $10^{-50}$, por exemplo) e ainda serem muito próximos uns dos outros, houve a necessidade de se trabalhar com uma função não-linear no filtro, pois o mapeamento para os valores inteiros da barra de rolagem fazia com que a maioria das arestas desaparecesse somente quando a barra de rolagem estava bem próxima a zero ou até mesmo em zero. A solução adotada foi utilizar uma função raiz quadrada, permitindo que os valores reais fossem mais uniformemente mapeados sobre os valores inteiros da barra de rolagem. 


\subsubsection{Janela de busca}

A janela de busca apresenta os resultados de uma busca efetuada pelo usuário. Inicialmente, o sistema de busca verifica se a busca é por rótulos de vértices ou por trechos de seqüências. Uma sequiência só pode conter as letras A, T, C, G e N. Logo, caso alguma outra letra ou dígito esteja presente na string para consulta, então a busca é feita entre os rótulos dos vértices que estão armazenados em estruturas do próprio programa, não havendo a necessidade de fazer acesso ao banco de dados. Caso contrário, a busca é feita por trechos de seqüências e, agora sim, ocorre uma consulta ao banco de dados.

Os resultados de uma busca são listados em um arquivo no formato HTML para serem exibidos. O número de entradas desta lista está limitado a 50, mesmo que sejam retornados mais resultados, pois uma busca extremamente simples (por exemplo, se o usuário digitar 'A') resulta em milhões de dados retornados como resposta. Caso isso ocorra, o usuário é informado a ser mais específico em sua busca. Todos os rótulos retornados aparecem em forma de links e, quando clicados, alteram a disposição do grafo na tela. Ainda, se a busca é feita por rótulos, os trechos dos rótulos da lista de resultados que são iguais à string da consulta aparecem em negrito, semelhante ao que acontece em grandes sites de busca como Google ${ }^{1}$ e Yahoo! ${ }^{2}$ (ver Figura 5.3). Quando a busca é feita por trechos de sequiência, este efeito só poderá ser visto se o usuário abrir a janela de detalhes do vértice (ver Seção 5.1.3).

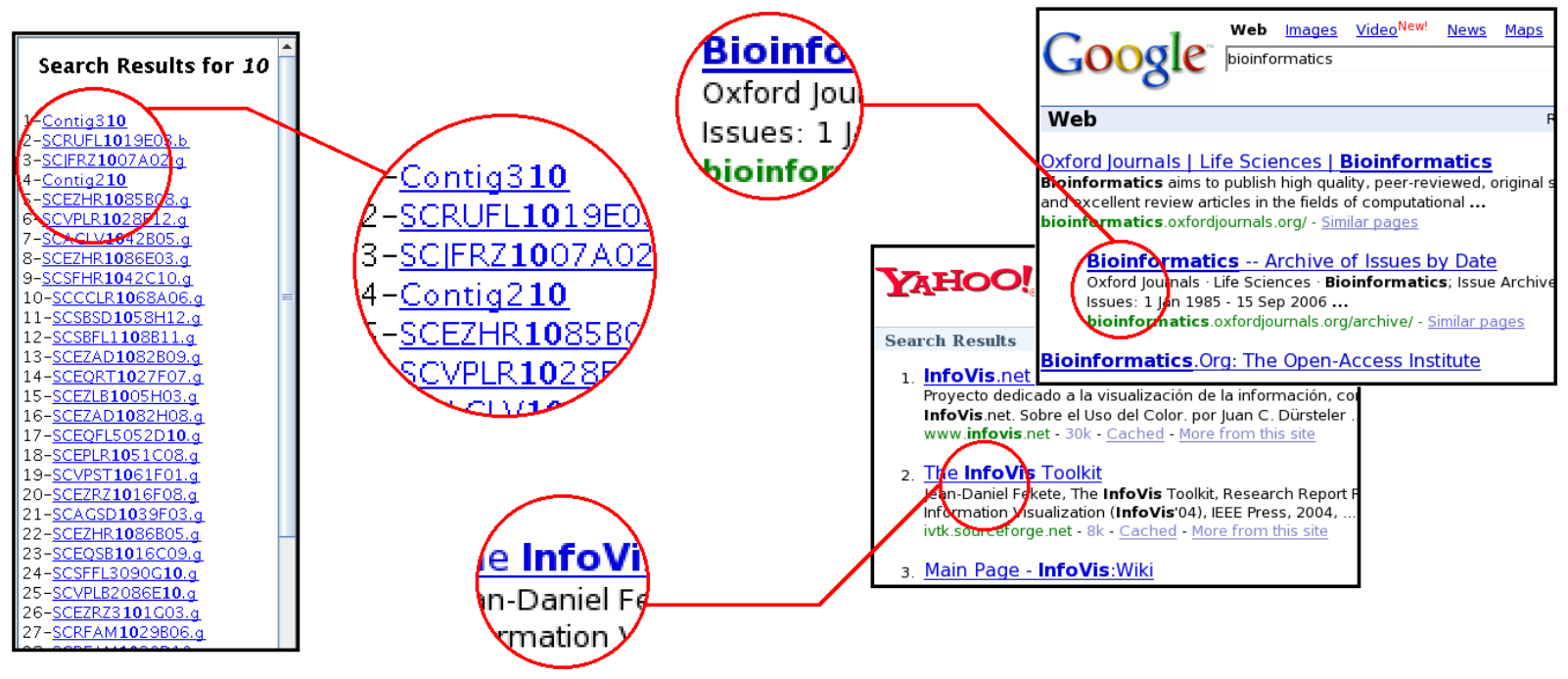

Figura 5.3: À esquerda, a janela de busca e à direita, os sites: Google e Yahoo!. Nos círculos vermelhos, detalhes do negrito sobre o resultado.

\footnotetext{
${ }^{1}$ http: //www.google.com/.

${ }^{2}$ http: //www . yahoo.com/.
} 


\subsubsection{Janela de apresentação do grafo}

A janela de apresentação do grafo é a janela principal do programa. Nela, o usuário tem liberdade para interagir diretamente nos vértices e nas arestas. Aqui estão implementadas as interações que possuem um aprendizado mais rápido, pois se resumem aos efeitos causados pela manipulação do mouse.

Ao passar o ponteiro do mouse sobre um vértice, os vértices vizinhos a ele são imediatamente destacados em vermelho (ver Figura 5.4), com exceção daqueles que ou estão selecionados (em cinza) ou não tem arestas direcionadas para eles, mas sim que vêm deles. Para selecionar um vértice basta que o usuário clique em cima dele com o botão esquerdo do mouse, tornando sua cor cinza. É possível selecionar vários vértices na tela (ver Figura 5.4). O duplo-clique do botão esquerdo do mouse sobre um vértice, além de selecioná-lo, pode mudar o foco para ele, pois são aplicados os filtros de raio e do número máximo de arestas permitidas para que os vértices possam ser mostrados ou expandidos. Com isso, é possível que sejam escondidos alguns vértices e arestas e outros mais próximos do novo vértice em foco apareçam.

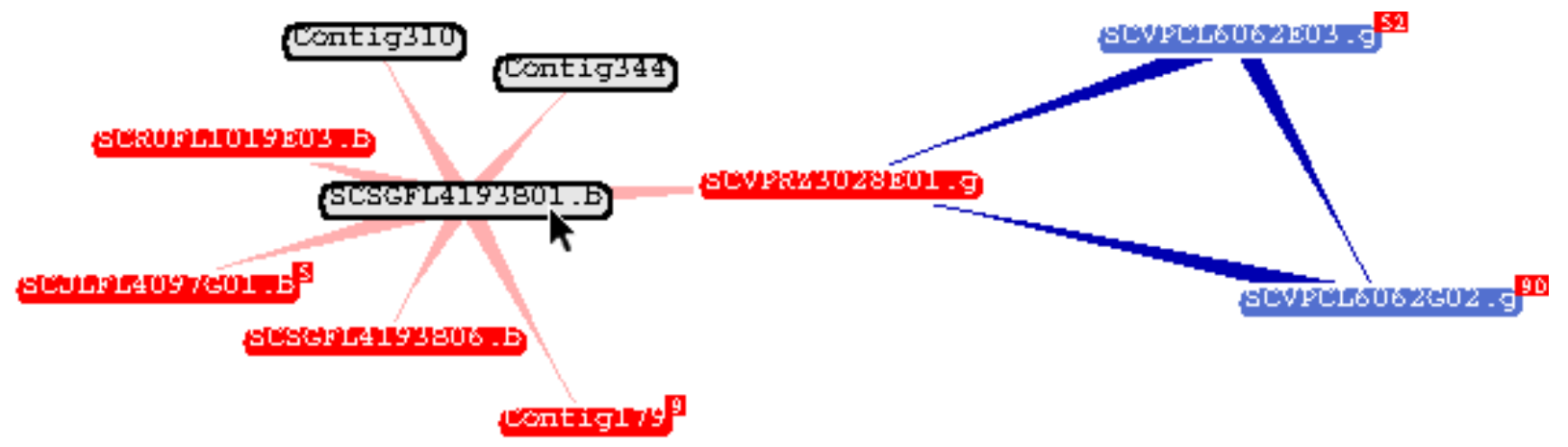

Figura 5.4: Destaque dos vértices vizinhos ao vértice com rótulo 'SCSGFL4193B01.b'. Os vértices rotulados com 'Contig310' e 'Contig344' não são destacados pois estão selecionados.

É possível realizar mais interações com um clique do botão direito do mouse. Um menu diferente para cada tipo de objeto na tela (vértices, arestas ou o plano de fundo) aparece quando o usuário clica com o botão direito sobre ele (ver Figura 5.5). O menu que aparece sobre uma aresta possibilita apenas a ação de escondê-la. О menu de um vértice permite escondê-lo, colapsá-lo, expandi-lo ou mostrar os detalhes de sua sequiência, como o agrupamento e a sequiência consenso, caso eles existam. Ao selecionar a opção de mostrar detalhes das seqüências, é feito um acesso ao banco de dados para selecionar a seqüência consenso e o rótulo de todas as sequiências que fazem parte de um agrupamento não unitário ou somente a sequiência do agrupamento que for unitário (ver Figura 5.6). As opções de esconder vértices e arestas são formas de filtragem, enquanto mostrar os detalhes das seqüências é uma forma de apresentar detalhes sob demanda (ver discussão sobre formas de interação no Capítulo 2). O menu que aparece sobre o plano de fundo permite esconder ou apresentar a barra de funcionalidades, tirar a seleção de todos os vértices até 
então selecionados ou fazer uma chamada ao montador CAP3 (ver Capítulo 4) para os vértices selecionados. Esta última tarefa pode interromper a execução da ferramenta de visualização por alguns segundos até que o CAP3 emita a sua saída. Na volta da execução da ferramenta, os vértices que tiverem sido remontados desaparecem, dando origem a novos vértices, apresentados em uma cor diferente indicando sua remontagem, enquanto aqueles que não são remontados permanecem com a cor cinza (ver Figura 5.7).

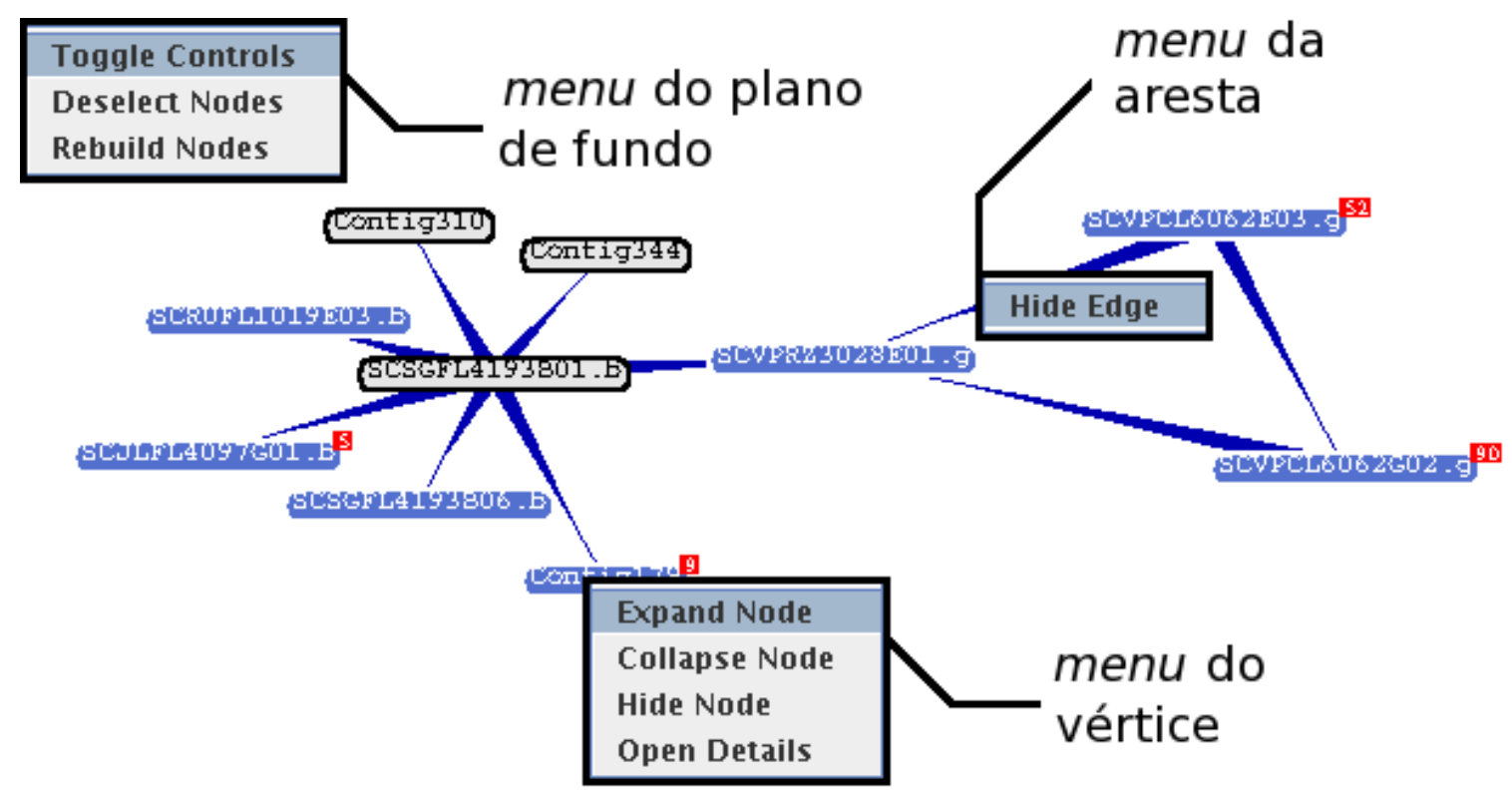

Figura 5.5: Os menus para vértices, arestas e plano de fundo.

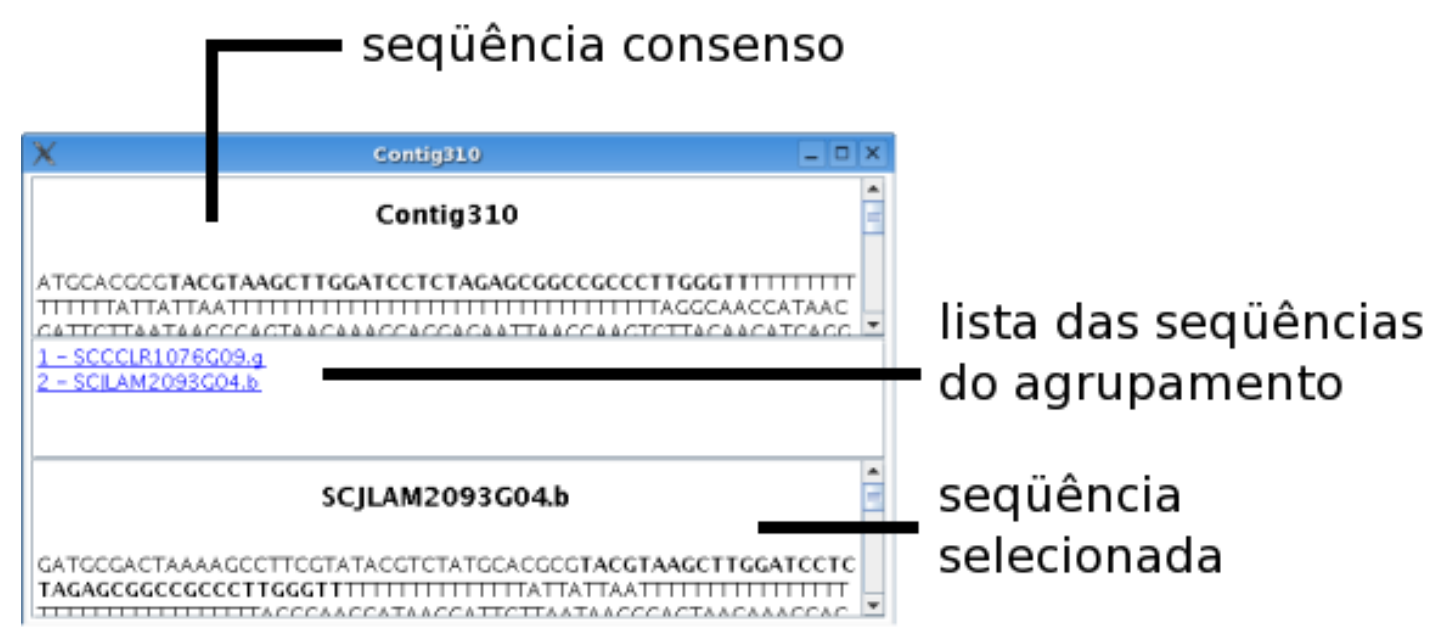

Figura 5.6: Detalhes do agrupamento 'Contig310'. Trechos das sequiências que aparecem em negrito são resultados de uma busca efetuada pelo usuário. 


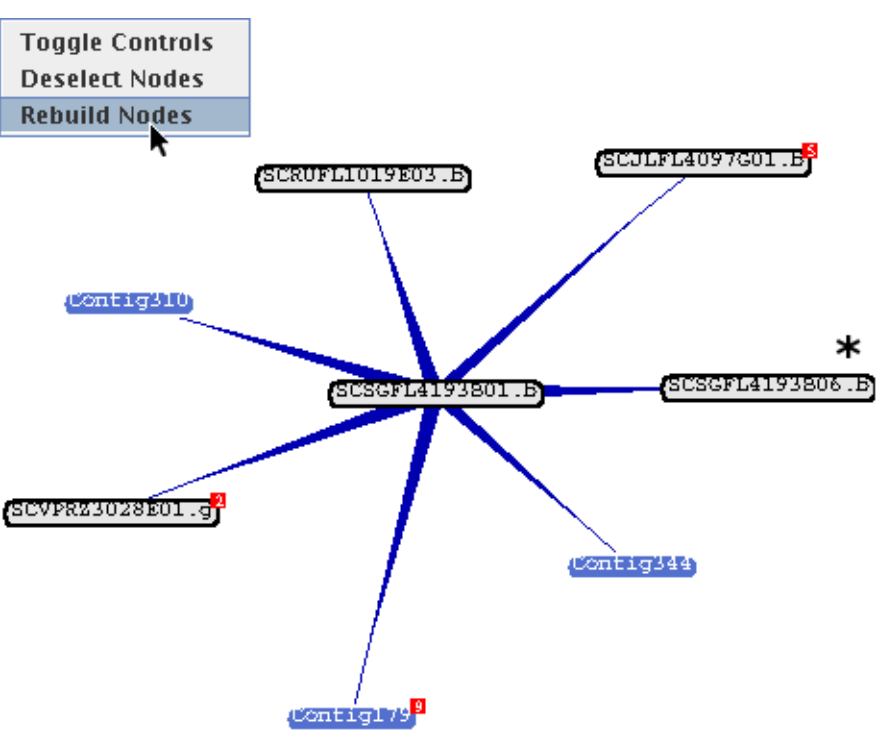

(a)

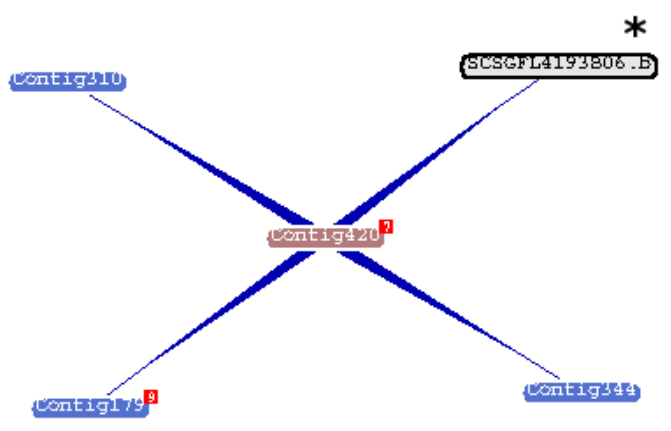

(b)

Figura 5.7: (a) Selecionando opção de remontagem dos vértices selecionados. (b) Após a remontagem, o agrupamento 'Contig420' é gerado. O único vértice não montado permanece cinza, indicado pelo asterisco.

\subsection{Desempenho}

Devido ao acréscimo no número de funcionalidades implementadas para a ferramenta, sendo a maioria delas com efeito em tempo real, surgiu também a preocupação com o seu desempenho. Alguns estudos foram realizados sobre o consumo de memória e sobre restrições impostas pela própria natureza do algoritmo de desenho do grafo. Os dados utilizados para os testes foram obtidos do projeto SUCEST e de bancos de dados públicos. Além disso, foram realizadas melhorias no código com a intenção de obter melhores resultados na animação. Os testes foram realizados em um computador com a seguinte configuração: processador Intel Pentium 4, CPU de $2.0 \mathrm{GHz}$ e 1 GB de memória RAM em um sistema operacional Linux Slackware 10.1 com kernel versão 2.6.14.

Em todos os testes realizados não foi constatado um consumo excessivo de memória por parte da nova ferramenta, não havendo acréscimo de consumo em relação à ferramenta original. Em geral, quanto maior é o arquivo de entrada mais memória é utilizada. Por exemplo, para arquivos contendo cerca de $100 \mathrm{~KB}$ de dados, registrou-se um consumo médio de $5 \mathrm{MB}$ de memória do sistema, enquanto que para arquivos contendo mais de $2 \mathrm{MB}$ de dados, registrou-se um consumo em torno de $15 \mathrm{MB}$ de memória. Entretanto, não é recomendável que o arquivo de entrada seja muito extenso, uma vez que o carregamento de arquivos com números relativamente altos de vértices e arestas resulta em um dos maiores problemas da nossa abordagem: a quantidade de tempo necessária para a inicialização do programa. A Tabela 5.1 mostra o tempo consumido para que se carregue a ferramenta com diferentes tamanhos de conjuntos de dados. A partir da tabela, é 
possível perceber que à medida em que um arquivo é maior, o tempo de inicialização sofre um sensível acréscimo. Além disso, os tempos de inicialização aumentam drasticamente quando o grafo contido em um arquivo é muito denso, ou seja, quando o grau médio dos vértices é grande.

\begin{tabular}{|c|c|c|c|c|}
\hline \multicolumn{4}{|c|}{ Arquivo } & \\
\hline Tamanho (MB) & Vértices (V) & Arestas (A) & Grau médio (A/V) & Tempo (s) \\
\hline 0.4 & 1.961 & 16.049 & 8,18 & 4 \\
\hline 1.5 & 3.065 & 77.755 & 25,37 & 80 \\
\hline 2.4 & 4.105 & 126.179 & 30,74 & 210 \\
\hline 2.0 & 13.691 & 95.069 & 6,94 & 118 \\
\hline
\end{tabular}

Tabela 5.1: Tempos de inicialização para conjuntos de dados de dados de diferentes tamanhos. As três primeiras linhas são relativas aos ESTs do projeto SUCEST. A última linha é relativa a um arquivo contendo ESTs coletados do DNA do mosquito Aedes aegypti, disponível para download no site Ensembl.

Outro ponto que pode ser considerado como fraco do algoritmo TouchGraph diz respeito à movimentação do grafo. Quando o usuário deseja mover um vértice para poder enxergar o que há por trás dele, todo o grafo se movimenta, obstruindo a visualização de alguma informação. Para contornar este problema, o programa permite esconder vértices e arestas, facilitando este tipo de exploração. O que mais pesa contra o algoritmo de desenho é sua complexidade, $O\left(n^{2}\right)$, onde $n$ representa o número de vértices visíveis. Cada vértice presente na imagem tem influência na movimentação de todos os outros vértices visíveis. Desta forma, à medida que o usuário expande o grafo, a animação tende a ficar cada vez mais comprometida. Portanto, não é recomendável que se tente visualizar centenas de vértices ao mesmo tempo. Esta deficiência pode ser confirmada por uma análise da Tabela 5.2.

Por se tratar de uma ferramenta interativa e que depende muito da qualidade da animação, realizaram-se alguns testes para descobrir a quantidade de quadros desenhados a cada segundo (fps). A Tabela 5.2 mostra quantos quadros por segundo são atingidos para as animações sob o efeito das diversas interações descritas e com quantidades diferentes de vértices e arestas visíveis. Os valores apresentados dos fps na tabela são os valores de pior caso verificados para os processos. Portanto, os valores médios são superiores àqueles apresentados. É importante ressaltar que os valores apresentados para as interações de expansão e filtragem por $e$-value não correspondem exatamente à quantidade de vértices e arestas apresentadas na tabela, pois ao final destes processos o número de objetos visíveis é maior e menor, respectivamente. Por exemplo, a expansão realizada no grafo com 114 vértices e 242 arestas resulta em quase 300 vértices e mais de 1000 arestas visíveis. Já a expansão apresentada com 182 vértices e 808 arestas resulta em 350 vértices e quase 1400 arestas visíveis. Podemos concluir que, para grafos com pouco mais de 100 vértices visíveis, todos as interações, com exceção feita à expansão de vértices, ainda causam uma animação aceitável.

Foram realizados alguns testes para mostrar que diferentes conjuntos de dados podem ocasionar diferentes percepções de visualização. Utilizando os mesmos filtros, pôde-se perceber que 


\begin{tabular}{|c|c|c|c|c|c|}
\cline { 2 - 6 } \multicolumn{1}{c|}{} & \multicolumn{5}{c|}{ fps } \\
\hline N. de Vértices/Arestas & Ocioso & Zooming & Dragging & E-value & Expansão \\
\hline $8 / 7$ & 41 & 40 & 40 & 40 & 36 \\
\hline $24 / 53$ & 41 & 40 & 40 & 40 & 17 \\
\hline $76 / 203$ & 34 & 22 & 18 & 23 & 4 \\
\hline $114 / 242$ & 25 & 13 & 13 & 15 & 3 \\
\hline $182 / 808$ & 6 & 3 & 4 & 5 & 1 \\
\hline
\end{tabular}

Tabela 5.2: Quadros por segundo atingidos durante a animação com diferentes interações e números de objetos visíveis. As interações de expansão e do filtro $e$-value aumentam e diminuem, respectivamente, o número de objetos visíveis na tela e, portanto, suas taxas de animações não correspondem exatamente ao número de objetos informados na tabela.

o resultado da visualização para ESTs do projeto SUCEST (de cana-de-açúcar) é bastante diferente daquele para ESTs obtidos do site Emsembl (de mosquito Aedes aegypti). A Figura 5.8 ilustra um exemplo de diferenças percebidas na visualização dos conjuntos de dados onde, após a aplicação do filtro de $e$-values, muitos ESTs do projeto SUCEST permanecem ligados, enquanto o mesmo evento com os ESTs do mosquito Aedes aegypti faz com que eles se desconectem bastante, mostrando várias componentes desconexas na tela. Pode-se concluir que os $e$-values dos ESTs de cana-de-açúcar são menores do que aqueles dos ESTs do mosquito Aedes aegypti, indicando que as ligações entre os primeiros ESTs são mais "confiáveis" do que as ligações entre os últimos.

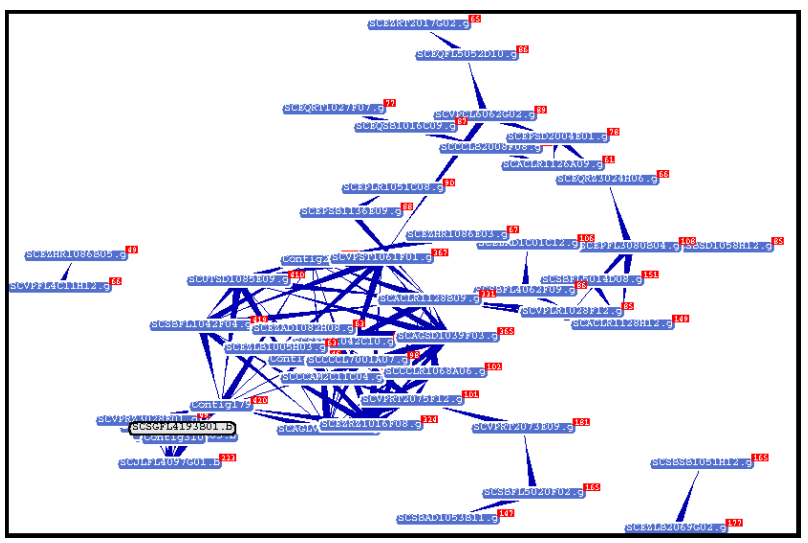

(a)

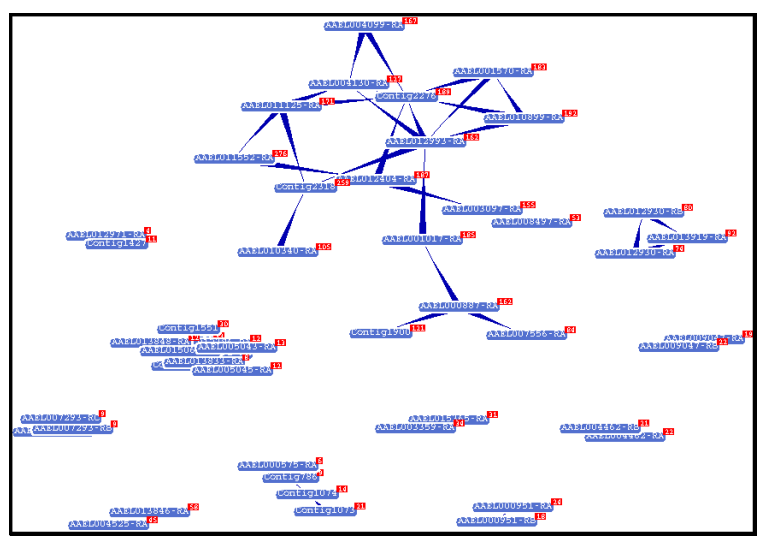

(b)

Figura 5.8: Diferenças de visualização em diferentes conjuntos de dados. (a) ESTs do projeto SUCEST após a aplicação do filtro de e-values. (b) ESTs do mosquito Aedes aegypti após a aplicação do mesmo filtro.

\subsection{Considerações finais}

Este capítulo reuniu alguns dos resultados alcançados neste trabalho. A ferramenta produzida disponibiliza várias ações interativas, de fácil aprendizado e com efeito instantâneo para a visuali- 
zação de ESTs. Além disso, a visualização é intuitiva e a animação, na maioria das vezes, possui uma taxa de atualização agradável ao ser humano.

Como todos os filtros trabalham concorrentemente com a apresentação do grafo e as arestas se comportam como molas, as animações produzidas são de boa qualidade para grafos de pequeno e médio porte. Para explorar um grafo de grande porte, a estratégia é esconder um trecho antes de expandir outro. Se houver o desejo de explorar um grafo de grande porte por completo na tela, recomenda-se a utilização de outros algoritmos de desenho com menor complexidade ou animação de qualidade inferior.

Em termos de funcionalidades, os filtros, as interações por cliques e as consultas proporcionam uma abordagem exploratória simples e fácil para o usuário. Enquanto isso, em termos de desempenho, deve-se avançar no estudo para buscar maneiras de reduzir o tempo de inicialização da ferramenta. A necessidade de carregar dois grandes arquivos de dados, sendo um para os vértices e outro para os pesos das arestas, trouxe um acréscimo significativo para a inicialização da ferramenta. Este e outros assuntos são discutidos dentro dos trabalhos futuros (ver Capítulo 6).

O próximo capítulo traz as conclusões deste estudo, apontando algumas melhorias que podem ser realizadas futuramente. 


\section{CAPítulo \\ 6}

Conclusões

Este trabalho apresentou uma metodologia e uma ferramenta baseada no desenho de grafos para visualizar ESTs e seus relacionamentos. Estes dados são muito importantes para a genética, tanto no estudo dos genes quanto das proteínas, pois são formas intermediárias entre genes e proteínas. Unindo as áreas de bioinformática e visualização de informação, foi possível ajustar os dados genéticos para serem visualizados por uma ferramenta de visualização de grafos. A ferramenta em questão foi desenvolvida com base na ferramenta TG WikiBrowser, utilizando o módulo TouchGraph, que possui grande aceitação em diversas áreas. A escolha pelo formato de grafos foi devida à necessidade do grupo de explorar esta área. A ferramenta implementada possui diversos recursos interativos, proporcionando uma navegação exploratória fácil e agradável sobre o conjunto de dados.

A forma encontrada para mapear os dados genéticos em um grafo foi a seguinte: com a utilização do programa CAP3 foi possível associar os ESTs aos vértices de um grafo, montando grupos de seqüências; com o algoritmo BLAST foram determinadas as arestas entre os vértices, alinhando trechos das seqüências. Alguns scripts escritos em Perl foram utilizados para coletar os dados úteis produzidos por estas ferramentas. Esta foi a contribuição da bioinformática neste estudo. Sobre a visualização, após a avaliação de algumas ferramentas de visualização de grafos, buscou-se uma que fosse livre e já disponibilizasse boa visualização, bem como ferramentas interativas de exploração. A ferramenta escolhida foi a TG WikiBrowser. Aliado a isso, foi criado um banco de dados para auxiliar em consultas dinâmicas sobre as seqüências e, assim, agregar mais informação aos dados explorados.

A ferramenta produzida neste trabalho apresenta diversas funcionalidades para a manipulação dos dados, como aquelas apresentadas no Capítulo 5. As interações foram desenvolvidas baseadas 
nas classificações de interação, apresentadas no Capítulo 2, e em observações pessoais sobre outras aplicações. Entre as principais características da ferramenta, pode-se destacar:

- Animação e exploração agradáveis;

- A portabilidade da ferramenta, desenvolvida em linguagem interpretada para ambientes Windows e Linux;

- A filtragem de arestas através dos e-values produzidos por alinhamentos;

- A remontagem de vértices selecionados pelo usuário através do programa CAP3;

- A conexão com o banco de dados, possibilitando consultas dinâmicas sobre as seqüências;

- O sistema de busca por rótulos ou trechos de seqüências sem precisar de indicação do usuário para isso;

- A inspeção de detalhes em demanda de seqüências e grupos de seqüências;

- O histórico da navegação nos vértices, permitindo voltar e avançar nos vértices percorridos.

Alguns testes foram realizados para medir o desempenho da ferramenta envolvendo o consumo de memória, o tempo de inicialização e a taxa de atualização de quadros durante a animação ( $f p s)$. Os resultados apontam que o tempo de inicialização é o ponto mais fraco da nossa abordagem. Devido à natureza do algoritmo TouchGraph de desenho de grafo, a taxa de atualização da animação mostrou-se bastante aceitável para a visualização de pouco mais de uma centena de vértices simultaneamente. Porém, a visualização simultânea de várias centenas de vértices compromete a animação. Para a exploração de um grafo de grande porte a ferramenta possui dispositivos para filtrar e esconder vértices e arestas.

Esperamos que este trabalho traga mais uma opção aos biólogos na exploração de sequiências gênicas, em especial, ESTs. A visualização, associada com dispositivos interativos, pode sugerir novas interpretações e gerar novas hipóteses sobre os dados trabalhados.

\subsection{Trabalhos futuros}

O que está disponível até o presente momento é uma ferramenta interativa de visualização e exploração de ESTs que possui algumas funcionalidades interessantes como a fácil exploração e a consulta dinâmica às seqüências. No entanto, algumas melhorias podem ser incorporadas para aumentar a interatividade e facilitar ainda mais a investigação dos dados. Ainda, deve-se trabalhar em formas de melhorar o desempenho da ferramenta no que diz respeito ao seu tempo de inicialização. Algumas melhorias sugeridas são:

- A separação real de vértices, produzindo novos vértices entre os dados originais; 
- O carregamento dos vértices do arquivo em partes e não em sua totalidade;

- Fornecer área para anotações e serviços remotos, como cruzar dados da base local com bases de dados on-line e utilizar outras ferramentas disponíveis na web;

- A utilização de cores e formas sobre os vértices e sequiências para aumentar ou diminuir a representatividade dos mesmos;

- A seleção e gravação de partes dos grafos.

Pode-se propor ainda que o método de geração das arestas mais significativas seja melhorado e que ocorra a visualização dos dados de maneiras diferentes e em outras ferramentas para permitir futuras comparações de resultados. 
454 LifE ScIEnCES Measuring life - one genome at a time. http://www. 454 .com/. Novembro, 2006.

Adams, M. D.; Kelley, J. M.; Gocayne, J. D.; Dubnick, M.; Polymeropoulos, M. H.; Xiao, H.; Merril, C. R.; Wu, A.; Olde, B.; Moreno, R. F.; et al. Complementary DNA sequencing: expressed sequence tags and human genome project. Science, v. 252, n. 5013, p. 1651-1656, 1991.

Ahlberg, C.; Wistrand, E. IVEE: An information visualization \& exploration environment. In: Proceedings of Information Visualization '95, 1995, p. 66-73.

Altschul, S. F.; Gish, W.; Miller, W.; Myers, E. W.; Lipman, D. J. Basic local alignment search tool. J. Mol. Biol., v. 215, p. 403-410, 1990.

Altschul, S. F.; Madden, T. L.; Schäffer, A. A.; Zhang, J.; Zhang, Z.; Miller, W.; LIPMAN, D. J. Gapped BLAST and PSI-BLAST: a new generation of protein database search programs. Nucleic Acids Research, v. 25, n. 17, p. 3389-3402, 1997.

AMAZON A tool for browsing the mass of literature, music and film contained in the amazon database, by exploring links between related items. http://www.pmbrowser.info/ amazon. html. Dezembro, 2006.

BAUR, M.; BRANDES, U. Graph-theoretic concepts in computer science, cáp. Crossing Reduction in Circular Layouts. Springer Berlin / Heidelberg, p. 332-343, 2004.

Bearman, P. S.; Moody, J.; Stovel, K. Chains of affection: The structure of adolescent romantic and sexual networks. American Journal of Sociology, v. 110, n. 1, p. 44-91, 2004.

Becker, M. Y.; RojAs, I. A graph layout algorithm for drawing metabolic pathways. Bioinformatics, v. 17, n. 5, p. 461-467, 2001. 
Biotage Pyrosequencing - one hour to explicit sequence data. http://www. pyrosequencing.com/. Novembro, 2006.

BISTIC National institutes of health working definition of bioinformatics and computational biology. Biological Information Science and Technology Consortium Definition Committee, 2000.

Bondy, J. A.; Murty, U. R. Graph theory with applications. MacMillan/Elsevier, 1976.

BROOKLYN COLLEGE Biological information. http://www.brooklyn.cuny.edu/. Abril, 2006.

CARD, S. K.; Mackinlay, J.; ShNeIderman, B. Readings in information visualization: Using vision to think. San Francisco, USA: Morgan Kaufmann Publishers, 1999.

Chuah, M. C.; Roth, S. F. On the semantics of interactive visualization. In: Proceedings of IEEE Visualization '96, 1996, p. 29-36.

CLICRBS Tempo. http://www.clicrbs.com.br/clictempo/jsp/index.jsp. Agosto, 2006.

Cohen, R. F.; EAdes, P.; Lin, T.; Ruskey, F. Three-dimensional graph drawing. Algorithmica, v. 17, n. 2, p. 199-208, 1997.

CRUZ, I. F.; TAMASsiA, R. Graph drawing tutorial. http://www.cs.brown.edu/ people/rt/papers/gd-tutorial/gd-constraints.pdf. Agosto, 2006.

Dayhoff, M. O.; Schwartz, R. M.; Orcutt, B. C. A model of evolutionary change in proteins. Atlas of protein sequence and structure, v. 5, n. 3, p. 345-352, 1978.

Di Battista, G.; EAdes, P.; TAmassia, R.; Tollis, I. G. Graph drawing: Algorithms for the visualization of graphs. Upper Saddle River, NJ, USA: Prentice Hall PTR, 1998.

EAdES, P. A heuristic for graph-drawing. In Congressus Numerantium, v. 42, n. 1, p. 146-160, 1984.

EAdes, P.; Symvonis, A.; Whitesides, S. Three-dimensional orthogonal graph drawing algorithms. Discrete Apllied Mathematics, v. 103, p. 55-87, 2000.

Ewing, B.; Hillier, L.; Wendl, M. C.; Green, P. Base-calling of automated sequencer traces using Phred. I. Accuracy assessement. Genome Research, v. 8, p. 175-185, 1998.

Feng, Q.; EAdes, P.; Cohen, R. F. Planar drawing of clustered graphs. Relatório Técnico, University of Newcastle, 1995. 
Formella, A.; Keller, J. Generalized fisheye views of graphs. In: Proc. 3rd Int. Symp. Graph Drawing, GD, n. 1027, Berlim, Alemanha: Springer-Verlag, 1995, p. 242-253.

Fruchterman, T. M. J.; Reingold, E. M. Graph-drawing by force-directed placement. Software-Practice an Experience, v. 21, n. 11, p. 1129-1164, 1991.

GERHARDT, I. Programa criado por pesquisador da embrapa já foi acessado mais de 5 milhões de vezes em todo o mundo. Folha de São Paulo, 2001.

GreEN, P. Documentation for phrap and cross-match, http://bozeman.mbt. washington.edu/phrap.docs/, 1996.

Heber, S.; Alekseyev, M.; Sze, S.; Tang, H.; Pevzner, P. A. Splicing graphs and EST assembly problem. Bioinformatics, v. 18, n. 1, p. 181-188, 2002.

Herman, I.; Melançon, G.; Marshall, M. S. Graph visualization and navigation in information visualization: A survey. IEEE Transactions on Visualization and Computer Graphics, v. 6 , n. 1 , p. $24-43,2000$.

HGPI Genome glossary. http://www.ornl.gov/sci/techresources/Human_ Genome/glossary/. Julho, 2006.

Hibbard, W.; Levkowitz, H.; Haswell, J.; Rheingans, P.; Schroeder, F. Interaction in perceptually-based visualization. Perceptual Issues in Visualization, p. 23-32, 1995.

HUANG, X. A contig assembly program based on sensitive detection of fragment overlaps. Genomics, v. 18, n. 1, p. 18-25, 1992.

HUANG, X.; MADAN, A. CAP3: A DNA sequence assembly program. Genome Research, v. 9, p. $868-877,1999$.

INXIGHT Transforming text into actionable information. http://www. inxight.com/. Setembro, 2006.

KEIM, D. A. Visual exploration of large data sets. Communications of the ACM, v. 44, n. 8, p. 39-44, 2001.

KEIM, D. A. Information visualization and visual data mining. IEEE Transactions on Visualization and Computer Graphics, v. 8, n. 1, p. 1-8, 2002.

KeIM, D. A.; KRIEgEL, H. Visualization techniques for mining large databases: A comparison. Transactions on Knowledge and Data Engineering, v. 8, n. 6, p. 923-938, 1996.

LAMPING, J.; RAO, R. The hyperbolic browser: A focus context technique for visualizing large hierarchies. Journal of Visual Languages and Computing, v. 7, p. 33-55, 1996. 
Lipman, D. J.; Pearson, W. R. Rapid and sensitive protein similarity searches. Science, v. 227, p. 1435-1441, 1985.

Nascimento, H. A. D. User hints for optimization processes. Tese de Doutoramento, The School of Information Technologies, The University of Sydney, Australia, 2003.

NCBI Fasta format description. http://www.ncbi.nlm.nih.gov/blast/fasta . shtml. Dezembro, 2006.

Neshich, G.; Togawa, R. C.; Vilella, W.; Honig, B. Sequence To and withIN Graphics PDB Viewer (STING -PDB viewer). PDB Quarterly NewsLetter, p. 6-7, 1998.

NG, P. C.; Henikoff, J. G.; Henikoff, S. PHAT: A transmembrane-specific substitution matrix. Bioinformatics, v. 16, n. 9, p. 760-766, 2000.

Niggemann, O. Visual data mining of graph-based data. Tese de Doutoramento, Department of Mathematics and Computer Science of the University of Paderborn, Germany, 2002.

Oliveira, M. C. F.; Levkowitz, H. From visual data exploration to visual data mining: A survey. IEEE Transactions on Visualization amd Computer Graphics, v. 9, n. 3, p. 378-394, 2003.

Papakostas, A.; Tollis, I. G. Interactive orthogonal graph drawing. IEEE Transactions on Computers, v. 47, n. 11, p. 1297-1309, 1998.

Preparata, F. P.; UPfal, E. Sequencing-by-hybridization at the information-theory bound: an optimal algorithm. Fourth Annual International Conference on Computational Molecular Biology, 2000.

Purchase, H. C. Which aesthetic has the greatest effect on human understanding? In: Graph Drawing (Proc. GD '97), Springer-Verlag, Vol. 1353 of Lecture Notes Comput. Sci., 1997, p. 248-261.

Robertson, G. G.; CARD, S. K.; Mackinlay, J. D. Information visualization using 3d interactive animation. Commun. ACM, v. 36, n. 4, p. 57-71, 1993.

RubIN, S. M. Computer aids for VLSI design. Addison-Wesley Publishing Company, 1994.

SANDER, G. Graph layout through the VCG tool. In: Proc. DIMACS Int. Work. Graph Drawing, GD, n. 894, Berlim, Alemanha: Springer-Verlag, 1994, p. 194-205.

SANDER, G. Layout of compound directed graphs. Relatório Técnico, Universität des Saarlandes, 1996.

SAnger, F.; Nicklen, S.; Coulson, A. R. DNA sequencing with chain-terminating inhibitors. Proceedings of the National Academy of Sciences, v. 74, n. 12, p. 5463-5467, 1977. 
Sarkar, M.; Brown, M. H. Graphical fisheye views. Communications of the ACM, v. 37, n. 12, p. 73-84, 1994.

SChNeIDer, T. D.; Stephens, R. M. Sequence logos: a new way to display consensus sequences. Nucleic Acids Research, v. 18, n. 20, p. 6097-6100, 1990.

ShaPIRO, A. Touchgraph LLC. http: //www.touchgraph.com/. Dezembro, 2006.

ShNEIDERMAN, B. Dynamic queries for visual information seeking. IEEE Software, v. 11, n. 6, p. 70-77, 1994.

SHNEIDERMAN, B. The eyes have it: A task by data type taxonomy for information visualizations. In: IEEE Symposium on Visual Languages, Boulder, CO, EUA, 1996, p. 336-343.

SIX, J. M.; TOLLIS, I. G. Algorithm engineering and experimentation: International workshop ALENEX'99, cáp. Circular Drawings of Biconnected Graphs. Springer Berlin / Heidelberg, p. 57-73, 1999.

SouZA, G. The SUCEST-FUN project. https://sucestfun.cbmeg.unicamp.br/ sucestfun/. Março, 2006.

Stansfield, W. D.; Colomé, J. S.; CAno, R. J. Schaum's outline of theory and problems of molecular and cell biology. McGraw-Hill, 1996.

Stolte, C.; TAng, D.; Hanrahan, P. Polaris: A system for query, analysis, and visualization of multidimensional relational databases. IEEE Transactions on Visualization and Computer Graphics, v. 8, n. 1, p. 52-65, 2002.

SugiYama, K.; Misue, K. Graph drawing by magnetic-spring model. Journal of Visual Languages and Computing, v. 6, n. 3, 1995a.

SugiYama, K.; Misue, K. A simple and unified method for drawing graphs: Magnetic-spring algorithm. In: Graph Drawing, Princeton, 1994, Springer, 1995b, p. 364-375.

SugiYama, K.; TAgawa, S.; TodA, M. Methods for visual understanding of hierarchical system structures. IEEE Transactions on Systems, M and, Cybernectics, v. 11, n. 2, 1981.

Sutton, G. G.; White, O.; Adams, M. D.; Kerlavage, A. R. Tigr assembler: A new tool for assembling large shotgun sequencing projects. Genome Science \& Technology, v. 1, n. 1, p. 9-19, 1995.

SwaYne, D. F.; CoOK, D.; BuJA, A. XGobi: Interactive dynamic data visualization in the X Window System. Journal of Computational and Graphical Statistics, v. 7, n. 1, p. 113-130, 1998. 
TAmassia, R.; Tollis, I. G. Planar grid embedding in linear time. IEEE Transactions on Circuits and Systems, v. 36, n. 9, p. 1230-1234, 1989.

Telles, G. P. Um algoritmo quase-linear para árvores pqr e um esquema para clustering de seqüências expressas de cana-de-açúcar. Tese de Doutoramento, Unicamp, Brasil, 2002.

TOM SAWYER SOFTwARE Tom sawyer software. http://www.tomsawyer.com/home/ index.php. Setembro, 2006.

TOUCHGRAPH LLC Touchgraph googlebrowserv1.01. http://www.touchgraph.com/ TGGoogleBrowser. html. Dezembro, 2006a.

TOUCHGRAPH LLC Touchgraph livejournal browser v1.5. http://www.touchgraph . com/TG_LJ_Browser.html. Dezembro, 2006b.

Venter, J. C.; Adams, M. D.; et al. The sequence of the human genome. Science, v. 291, n. 5507, p. 1304-1351, 2001.

Voet, D.; Voet, J. G. Biochemistry. John Wiley \& Sons, Inc., 1995.

WARD, M. O. Xmdvtool: Integrating multiple methods for visualizing multivariate data. In: Proceedings of IEEE Visualization '94, Washington, DC, EUA, 1994, p. 326-336.

West, D. B. Introduction to graph theory. 2nd ed. Prentice Hall, 2001.

WIKIPEDIA Bioinformatics. http://en.wikipedia.org/wiki/Bioinformatics. Julho, 2006. 
alinhamento Sobreposição entre as bases de duas seqüências a fim de encontrar similaridades entre elas.

BLAST Basic Local Alignment Search Tool. Algoritmo que realiza o alinhamento local entre sequiências de DNA ou de proteínas.

CAP3 Contig Assembly Program 3. Programa que monta trechos de sequiências para formar contigs.

consenso Seqüência que representa um contig.

contig Grupo formado pela montagem de seqüências.

EST Expressed Sequence Tag. Pequeno trecho - produzido em laboratório - de um gene.

montagem Formação de grupos de seqüências similares a fim de construir seqüências maiores.

NCBI National Center for Biotechnology Information. Conduz pesquisa em biologia computacional com o desenvolvimento de softwares para a análise de dados genômicos.

singlet Contig unitário.

SUCEST Sugarcane EST Project. Projeto que produziu milhares de ESTs de cana-deaçúcar.

\section{TG WikiBrowser}

Ferramenta utilizada para a visualização de grafos representando links entre páginas de Internet. Neste trabalho foi adaptada para trabalhar com ESTs.

TIGR The Institute for Genomical Research. Instituto dedicado à análise de genomas. 
TouchGraph Ferramenta utilizada para a visualização de grafos com algoritmo de desenho baseado em força. Ela também dá origem a diversas outras ferramentas, como a TG WikiBrowser. 